\title{
In plain sight: the Chesapeake Bay crater ejecta blanket
}

\section{L. Griscom}

impactGlass research international, San Carlos, Sonora, México

Received: 31 January 2012 - Accepted: 6 February 2012 - Published: 14 February 2012

Correspondence to: D. L. Griscom (david_griscom @yahoo.com)

Published by Copernicus Publications on behalf of the European Geosciences Union.

\section{In plain sight: the Chesapeake Bay crater ejecta blanket \\ D. L. Griscom}

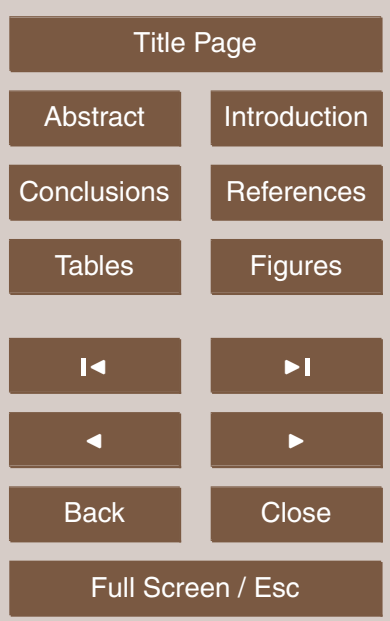

Printer-friendly Version

Interactive Discussion

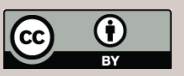




\section{Abstract}

The discovery nearly two decades ago of a $90 \mathrm{~km}$-diameter impact crater below the lower Chesapeake Bay has gone unnoted by the general public because to date all published literature on the subject has described it as "buried". To the contrary, evi5 dence is presented here that the so-called "upland deposits" that blanket $\sim 5000 \mathrm{~km}^{2}$ of the U.S. Middle-Atlantic Coastal Plain (M-ACP) display morphologic, lithologic, and stratigraphic features consistent with their being ejecta from the $35.4 \mathrm{Ma}$ Chesapeake Bay Impact Structure (CBIS) and absolutely inconsistent with the prevailing belief that they are of fluvial origin. Specifically supporting impact origin are the facts that (i) a $95 \%$-pure iron ore endemic to the upland deposits of southern Maryland, eastern Virginia, and the District of Columbia has previously been proven to be impactoclastic in origin, (ii) this iron ore welds together a small percentage of well-rounded quartzite pebbles and cobbles of the upland deposits into brittle sheets interpretable as "spall plates" created in the interference-zone of the CBIS impact, (iii) the predominantly non-welded 15 upland gravels have long ago been shown to be size sorted with an extreme cratercentric gradient far too large to have been the work of rivers, but well explained as atmospheric size-sorted interference-zone ejecta, (iv) new evidence is provided here that $\sim 60 \%$ of the non-welded quartzite pebbles and cobbles of the (lower lying) gravel member of the upland deposits display planar fractures attributable to interferencezone tensile waves, (v) the (overlying) loam member of the upland deposits is attributable to base-surge-type deposition, (vi) several exotic clasts found in a debris flow topographically below the upland deposits can only be explained as jetting-phase crater ejecta, and (vii) an allogenic granite boulder found among the upland deposits is deduced to have been launched into space and sculpted by hypervelocity air friction during reentry.

An idealized calculation of the CBIS ejecta-blanket elevation profile minutes after the impact was carried out founded on well established rules for explosion and impactgenerated craters. This profile is shown here to match the volume of the upland

\section{In plain sight: the Chesapeake Bay crater ejecta blanket}

D. L. Griscom

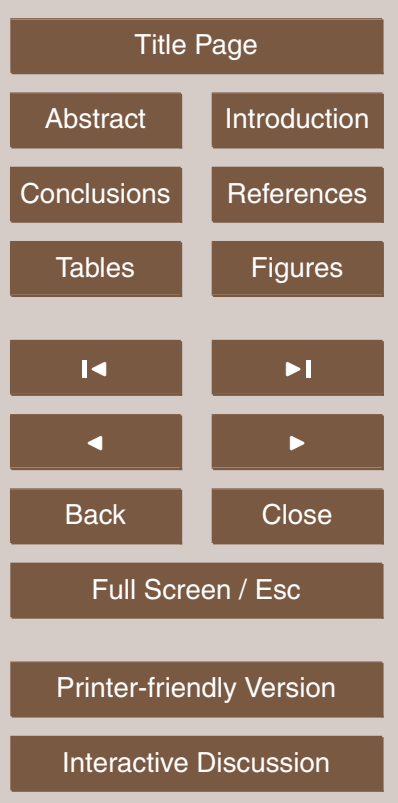


deposits $\geq 170 \mathrm{~km}$ from the crater center. Closer to the crater, much of the "postdicted" ejecta blanket has clearly been removed by erosion. Nevertheless the Shirley and fossil-free Bacons Castle Formations, located between the upland deposits and the CBIS interior and veneering the present day surface with units $\sim 10-20 \mathrm{~m}$ deep, are re5 spectively identified as curtain- and excavation-phase ejecta. The neritic-fossil-bearing Calvert Formation external to the crater is deduced to be of Eocene age (as opposed to early Miocene as currently believed), preserved by the armoring effects of the overlying CBIS ejecta composed of the (distal) upland deposits and the (proximal) Bacons Castle Formation. The lithofacies of the in-crater Calvert Formation can only have re10 sulted from inward mass wasting of the postdicted ejecta blanket, vestiges of which (i.e. the Bacons Castle and Shirley Formations) still overlap the crater rim and sag into its interior, consistent with this expectation.

Because there appear to be a total of $\sim 10000 \mathrm{~km}^{2}$ of CBIS ejecta lying on the present-day surface, future research should center the stratigraphic, lithologic, and 15 petrologic properties of these ejecta versus both radial distance from the crater center (to identify ejecta from different ejection stages) and circumferentially at fixed radial distances (to detect possible anisotropies relating the impact angle and direction of approach of the impactor).

The geological units described here may comprise the best preserved, and certainly 20 the most accessible, ejecta blanket of a major crater on the Earth's surface and therefore promise to be a boon to the field of impact geology. As a corollary, a major revision of the current stratigraphic column of the M-ACP will be necessary.

\section{Introduction}

From the moment of it's discovery, the conventional wisdom has been that virtually all 25

\section{SED}

4, 363-428, 2012

\section{In plain sight: the Chesapeake Bay crater ejecta blanket}

D. L. Griscom

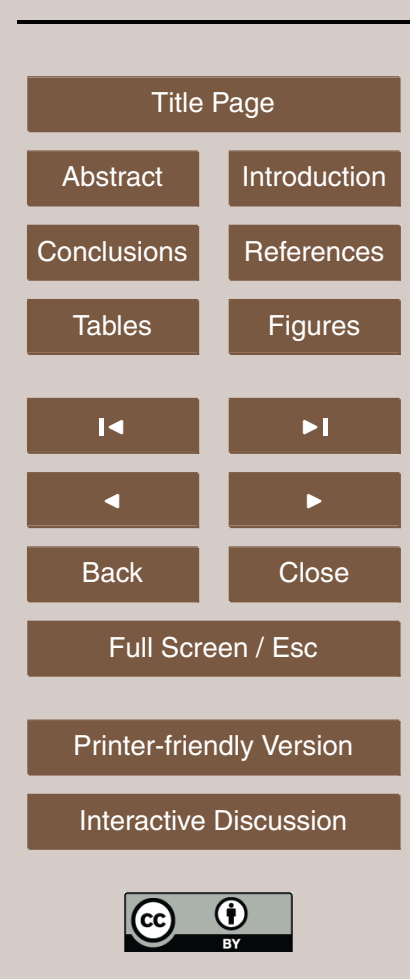


Coastal Plain (M-ACP) and the abutting Piedmont Province. All papers, books, and authoritative reviews found in the geological literature pertaining to this region tacitly imply that, except for the impact-related Exmore breccia extending to a maximum radial distance of $\sim 55 \mathrm{~km}$ (Poag, 1997), no other ejecta from this giant crater have ever 5 been identified on the present-day landward surface.

Notwithstanding this canonical belief, the author has been presenting evidence to the contrary at topical conferences for more than a decade (Griscom and Bolden, 1999; Griscom, 2001, 2002, 2007a, 2007b; Griscom et al., 2003). The materials-science part of this evidence (Griscom et al., 2003) lends important weight to the author's 10 geologically-based conclusion (Griscom, 2001, 2002, 2007a, 2007b) that $~ 5000 \mathrm{~km}^{2}$ of "upland deposits" mapped in Southern Maryland, Virginia, and the District of Columbia cannot possibly be fluvial deposits, as per the currently prevailing belief, whereas when viewed in the light of established principles of impact geology (Melosh, 1989) they can be confidently identified as ejecta from the CBIS.

15 Most significantly, Griscom et al., (2003) employed a wide range of solid-statephysical methods to characterize a type of $95 \%$-pure iron ore endemic to the "upland deposits," leading to their describing it as a peculiar nanocrystalline form of "ferric oxyhydroxide" characterized by atomic arrangements similar to goethite, $\alpha-\mathrm{FeOOH}$, but possibly including an amorphous component and possessing a hardness closer to that

on the basis of recent work by Michel et al. (2007), it now appears that this material is more likely a form of ferrihydrite, $\mathrm{Fe}_{10} \mathrm{O}_{14}(\mathrm{OH})_{2}$, given that the crystallite sizes of both materials are about the same: "typically $<10 \mathrm{~nm}$ " for ferrihydrite (Michel et al., 2007) and mean values of 8.9, 9.7, and $15.6 \mathrm{~nm}$ for the a- b- and c-axis dimensions determined by the Rietveld refinement method from an X-ray diffraction (XRD) pattern of a sample of the upland-deposits iron ore (G. Morin, Université de Paris 6, private communication, whose pattern, method, and fit have been published with permission by Griscom et al. (2003)). So, given that shock-induced dehydration of minerals is a well known process (Boslough, 1991), this upland iron ore will hence forth be termed a ferrihydrite.

\section{SED}

4, 363-428, 2012

\section{In plain sight: the Chesapeake Bay crater ejecta blanket}

D. L. Griscom

Title Page

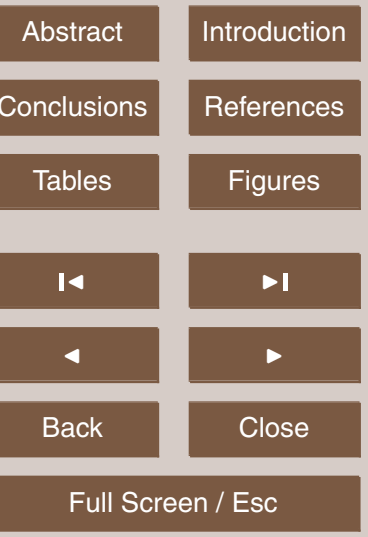

Printer-friendly Version

Interactive Discussion 
Thin-section photomicroscopy revealed these hard ferrihydrites to comprise the matrix material of a type of matrix-supported breccia ubiquitous to the upland deposits, leading Griscom et al. (2003) to conclude that (i) these must be melt-matrix breccias because iron oxide in water solution precipitates too slowly to solidify around the ob5 served "free floating" quartz clasts and therefore (ii) they must be impactoclastic in origin because there are no known igneous rocks composed of $95 \%$ pure iron oxide.

Section 2 of this paper reviews of the lithology, petrology, and geomorphography of the "upland deposits," mapped in Maryland by Schlee (1957) and Krantz and Powars (2000) and in Virginia as the "Chesapeake group" by G. H. Johnson and P. C. Peebles, 10 whose maps have been published by Frye (1986). Sect. 3 finds the fluvial model that has been historically used to explain the "upland deposits" to be palpably improbable by some measures and physically impossible by others. Conversely, Sect. 4 employs wellestablished experimental, observational, and theoretical principles of impact geology (Melosh, 1989) - plus the results of an original lithological study by the author - to 15 demonstrate that several distinctive stratigraphic, lithologic, and petrologic properties of the "upland deposits" fit expectation for the farthest flung but least shocked $\sim 10 \%$ of the CBIS ejecta, i.e. the interference-zone ejecta (Melosh, 1989).

Section 5 presents an original calculation of the minimum height-versus-radialdistance profile of the CBIS ejecta blanket minutes after its emplacement, based on a well established empirical property of large impact and explosion craters reviewed by Melosh (1989). Also discussed in this section are some likely effects of the solid target having been $\sim 150 \mathrm{~m}$ below sea level at the time of the impact.

Section 6 begins with a comparison of the calculated ejecta blanket profile with the topography of the eastern Virginia Coastal Plain and Piedmont, revealing the upland deposits to overlie topographic features virtually impossible to explain in terms of the canonical fluvial-deposition model but easily possible by ballistic emplacement. More significant, however, is the report of Wentworth (1928) that the Bacons Castle Formation (BCF) - occupying an annulus between the CBIS and the "upland deposits" (cf. Fig. 1) - is noted for its striated cobbles and boulders, a lithofacies previously
SED

4, 363-428, 2012

\section{In plain sight: the Chesapeake Bay crater ejecta blanket}

D. L. Griscom

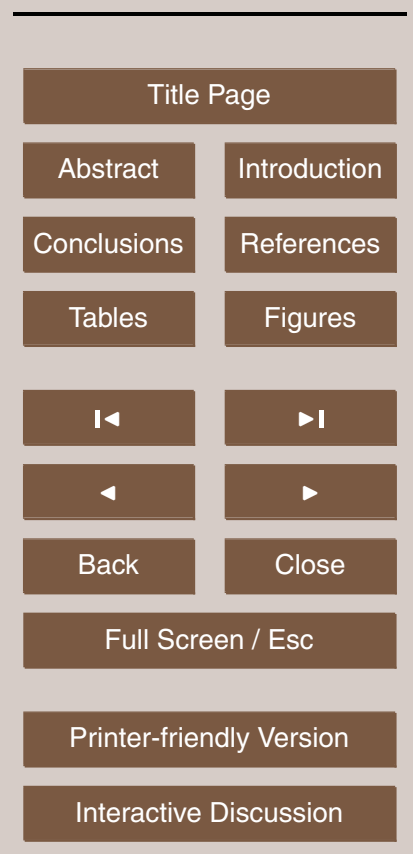


associated only with excavation-phase crater ejecta, e.g. (King et al., 1977). Section 7 treats possible influences of post-impact sea-level lowstands, paleoclimate, and the crater itself on the planktonic foraminiferal tests found in the crater in-fill (Poag, 1997) during the first $\sim 300$ k.y. of the crater's existence, and it also calls attention to apparent 5 fluvial paleochannels within the BCF circumferential to the CBIS, the likely presence of which is "postdicted" by inspection of the calculated ejecta blanket profile of Sect. 6.

In Sect. 8 the Shirley Formation, which surrounds and sags inside the CBIS crater rim, is deduced to be curtain ejecta. Section 9 seeks out points of agreement between the canonical model of the M-ACP and the model evolved in this paper, while 10 better defining the diametric natures of the disagreements. Section 10 reports field and laboratory studies of clasts from a siliciclastic debris flow discovered by the author topographically below the "upland deposits" in Northern Virginia, while Sect. 11 describes a unique granite boulder found within the "upland deposits," which is argued here to be a "meteorite from the Earth."

\section{The upland deposits: nomenclature and history}

The "upland deposits" - sometimes termed "upland gravels" or "upland terrace gravel" of the M-ACP are not consistently designated by a single formation name, despite their having been mapped over an area $\sim 5000 \mathrm{~km}^{2}$. Therefore, from here on the nomenclature "upland deposits" will be employed without quotation marks to denote the char-

acteristic lithofacies to be described below, wherever they may have been mapped (Fig. 1), irrespective of any other names that may have been historically assigned to them. The upland deposits of Southern Maryland (highlighted in Fig. 2) are denoted the Brandywine Formation.

A very important reason for not using the word "gravel" to characterize the upland 25 deposits is the fact that they actually comprise a bilayer consisting of a lower gravel member and an upper loam member, as reported in Southern Maryland by Hack (1955) and Schlee (1957), and in Virginia by Matthews et al. (1965), Goodwin and Johnson (1970), and others.

\section{SED}

4, 363-428, 2012

In plain sight: the Chesapeake Bay crater ejecta blanket

D. L. Griscom

Title Page

Abstract

Introduction

Conclusions

References

Tables

Figures

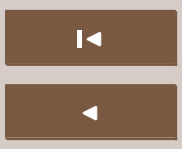

DI
Back

Close Full Screen / Esc

Printer-friendly Version

Interactive Discussion

$>$

(

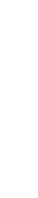


The origin of these unusual deposits had been controversial for well over a century when Schlee (1957) interpreted his important new data in terms of Hack's (1955) version of the fluvial-deposition model. In a handy overview of the geology of Virginia, Frye (1986) describes the upland deposits in terms of Hack's (1955) model, including 5 in particular his conclusion that these deposits were laid down by rivers in late-Miocene, Pliocene, or Pleistocene times, given that they overlie clay terraces long-before dated as early Miocene. Notably, however, the upland deposits themselves are devoid of fossils and therefore have been dated solely on the basis of the long-ago inferred ages of the fossils present in the shallow-water clay terraces that unconformably underlie them, 10 without confirmation by modern radiometric methods such as have been used to date the crater itself (Koeberl et al., 1996; Poag, 1997).

\subsection{The loam member}

According to Schlee (1957) the "massive" upper loam member consists chiefly of compacted silt with some sand, clay, and scattered pebbles, and ranges in color from paleyellowish-brown to grayish-orange to moderate-yellowish-brown. Hack (1955) reported this loam to comprise $90 \%$ quartz silt, with $2-5 \%$ heavy minerals.

For 30 years the author lived in a home perched on a steep embankment near the upper edge of a $\sim 65 \mathrm{~m}$-high clay plateau blanketed by upland deposits. The soil there comprised a pale-yellowish loam, which proved to be so coherent that grass roots of grass, showed no noticeable sign of pluvial erosion in 30 years.

Referring to the upland deposits near Midlothian, Virginia, Goodwin and Johnson (1970) note that "The edge of the gravel cover is usually marked by a pronounced steepening of hill slopes where the gravels have resisted erosion more effectively than

\section{SED}

4, 363-428, 2012

\section{In plain sight: the \\ Chesapeake Bay crater ejecta blanket}

D. L. Griscom

Title Page

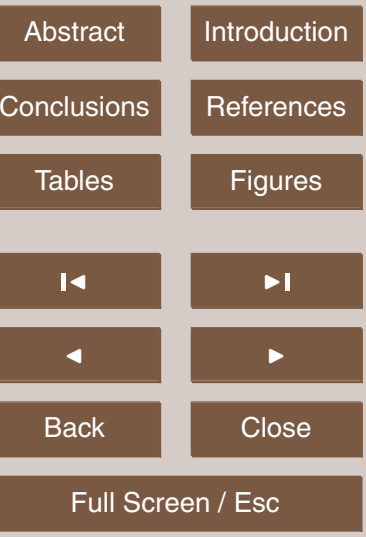

Printer-friendly Version

Interactive Discussion 


\subsection{The gravel member}

Schlee (1957) dedicated his field work to elucidating the lithology of the gravel member of the upland deposits, mainly in Southern Maryland (88 sites). However, he also sampled the District of Columbia (7 sites) and Northern Virginia (3 sites $\sim 20 \mathrm{~km}$ west 5 northwest of the U.S. Capitol Building in Washington, DC).

The samples that Griscom et al. (2003) studied by materials-science methods, as well as several others illustrated here for the first time (Sects. 4 and 10), were collected in the Hollin Hills subdivision of Fairfax County, Virginia, $\sim 15 \mathrm{~km}$ south southwest of the Capitol Building. However, many of the author's best samples were trucked into his neighborhood as landfill from an excavation in Springfield, Virginia, $\sim 19 \mathrm{~km}$ southwest of the Capitol.

According to Schlee (1957), the gravel member is pale-to-dark-yellowish-orange to mottled pale-yellowish-brown poorly sorted gravel and sandy gravel, as well as very pale-orange gravelly clay. "The gravel member is fairly well stratified, and sedimentation 15 units (ranging from $2 \mathrm{~m}$ down to $5 \mathrm{~cm}$ thick) are easily recognized." "Where bedding is poor, sedimentation units up to $(5 \mathrm{~m})$ thick are present. Laterally the beds range from (30 to $60 \mathrm{~m}$ ) or more down to $(3 \mathrm{~m})$ or less in the case of sand lenses." (Here and elsewhere the metric units in parentheses commonly represent conversions of English units.)

$20 \quad$ Schlee (1957) continues: "The gravel has a bimodal size distribution and consists of a gravel framework, averaging $61 \%$ of the whole, and a matrix of sand, silt, and clay." This fact led him to conclude that the bed load of heavy gravel and the suspended load of sand "were deposited contemporaneously" ...very unusual, if not impossible for rivers. In fact, Schlee's (1957) carefully determined average gravel framework of $61 \%$ 25 is significantly less than the calculated value for random close packing of spheres, $64 \%$ (Jaeger and Nagle, 1992).

\section{SED}

4, 363-428, 2012

\section{In plain sight: the Chesapeake Bay crater ejecta blanket}

D. L. Griscom

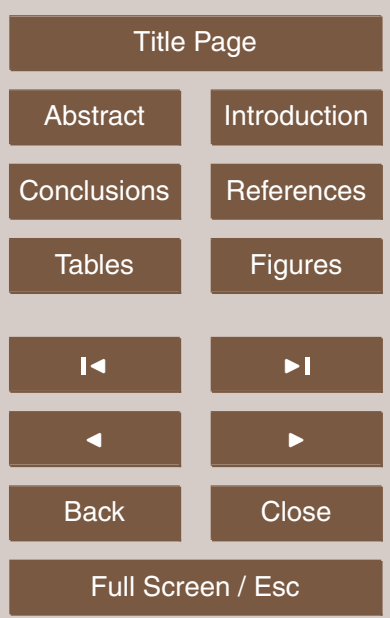

Printer-friendly Version

Interactive Discussion 


\subsection{Correlation of the upland deposits of Southern Maryland with those of Eastern Virginia}

If all of the upland deposits mapped in Fig. 1 came out of the Chesapeake Bay crater, then any given mapped locality should be lithologically similar to all others. Strong

5 support for this notion comes from the fact that Wentworth's (1930) extensive field work led him to apply the name Brandywine (originally applied only to Southern Maryland) to the upland deposits of eastern Virginia. Moreover, note the similarity of the following descriptions of two widely separated upland-deposit locations - the former being an average the northern half of Southern Maryland and the latter pertaining to a small cluster of sites just west of Richmond, Virginia. These sampl laterally by an average distance of $\sim 140 \mathrm{~km}$, vertically by $\sim 40 \mathrm{~m}$, and angularly by $\sim 60^{\circ}$ with respect to the center of the CBIS:

\subsubsection{Schlee (1957) RE the upland deposits of Southern Maryland}

(i) Describing the gravel member only: "The predominance of mature siliceous rocks is one of the unusual features of the upland gravels..." "In the $64-$ to $128 \mathrm{~mm}$ size grade, quartzite usually far exceeds "vein" quartz and chert." "Other rock types constitute a few percent or less of the total."

(ii) A footnote penned by Schlee (1957): "The 'only fossil' seen by the author was Cassius madagascariensis spinella Clench, found at the gravel-loam interface near Silver Hill, Maryland... It is unlikely that a tropical marine form such as this... was indigenous to the upland deposits; it may have been buried by Indians." (See comment in Sect. 6.2.3.)

(iii) "Pseudo-bedding in the form of wavy bands, which parallel and transect the bedding at a low angle, occurs in many exposures. The bands are chocolate to ruddy brown, well indurated, and a fraction of an inch thick." "...secondarily introduced
SED

4, 363-428, 2012

In plain sight: the Chesapeake Bay crater ejecta blanket

D. L. Griscom

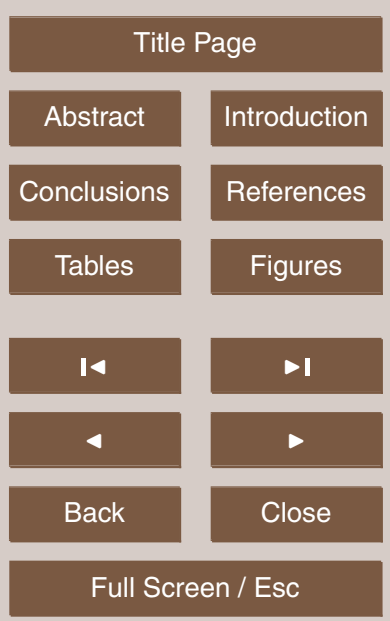

Printer-friendly Version

Interactive Discussion 
iron oxide ...locally cements the sand and gravel along definite zones and in large irregular masses up to $(1 \mathrm{~m})$ across."

(iv) Speaking of the upland deposits of Southern Maryland as a single unit: "This sheetlike deposit, which successively overlaps older formations to the northwest, has a fairly constant thickness of $(6$ to $9 \mathrm{~m})$ and dips southeastward at approximately $\left(1 \mathrm{~m} \mathrm{~km}^{-1}\right)$ " (in the general direction of the CBIS).

\subsubsection{Goodwin and Johnson (1970) RE the Midlothian gravels west of Richmond}

(i) "The most striking feature of the Midlothian gravels is the thick gravel member ...which ranges in thickness from zero to nearly $(12 \mathrm{~m})$ (and) is composed of abundant pebbles and cobbles in a sandy matrix containing variable amounts of clay. Although cobbles up to $(230 \mathrm{~mm})$ in maximum diameter were observed, the average cobble measures (50 to $75 \mathrm{~mm}$ ) in diameter." "The clasts are variable in composition but most are of some variety of quartz. Vein quartz, massive quartz, quartzite and quartz sandstone are the dominant lithologies comprising the clasts. A few clasts of other metamorphic rocks, igneous rocks, and chert constitute a minor portion of the gravels."

(ii) "No fossils have been found within the gravels to aid in determining their age or their origin."

(iii) "(Matthews et al., (1965)) subdivided the upland gravels into a lower gravel member and an upper loam member. Our studies indicate that a discontinuous basal cobble zone and overlying thick clay underlie the gravel member reported by Matthews. The basal cobble zone is one to four cobbles thick and is commonly solidly cemented by iron oxide to form a ferricrete zone."

(iv) "The $\left(\sim 60 \mathrm{~km}^{2}\right)$ upland gravels around Midlothian $(\sim 10 \mathrm{~km}$ west of Richmond, Virginia) are isolated and have been truncated by erosion on all sides." "Although locally the contact between the gravels and underlying rocks exhibits more than

In plain sight: the Chesapeake Bay crater ejecta blanket

D. L. Griscom

\section{Title Page}

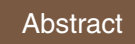

Introduction

Conclusions

References

Tables

Figures

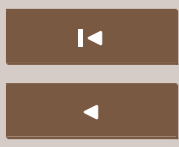

$>1$

Back

Close

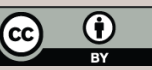


$(6 \mathrm{~m})$ of relief due to channeling, the surface of unconformity dips gently to the east or southeast at approximately $\left(1.7 \mathrm{~m} \mathrm{~km}^{-1}\right.$ )" (in the general direction of the CBIS).

\section{Testing the uniformitarian view of the upland deposits}

\section{3.1 Gravel-size gradient radial to the crater center}

Perhaps the most illuminating of Schlee's (1957) many contributions to our knowledge of the upland deposits was his discovery of the dramatic cobble-size gradient decreasing from 32-mm modal size in Washington, DC, down to $4 \mathrm{~mm}$ midway down the peninsulas bounded by the Potomac River and the Chesapeake Bay (Fig. 3a). In contemplating these data, Schlee (1957) observed that "The orderly changes in modal size in the northern portion of the sheet suggest that the size change may be a mathematical function similar to those found for size diminution in modern rivers." He therefore selected "four profiles parallel to the current flow direction and as far as possible normal to the size contours" and plotted these data on a semi-log graph where he was able to 15 fit them with a straight line (Fig. 3b).

Given that uniformitarian geology was "de rigueur" in those days, it is understandable that Schlee (1957) incorrectly described the slopes of the three curves being compared in Fig. $3 \mathrm{~b}$ as all being "of the same general order of magnitude." In fact, the mostly-quartzite cobble-size-reduction-rate slope that he was forced to attribute to the ancestral Potomac River is 15 times that of the modern Rhine River (Pettijean, 1949). Moreover, the data for the Rhine and Mur Rivers are not lithologically specific: In fact, the size-reduction rate for quartzite (Attal and Lavé, 2006) is 4 times lower than the overall rate reported for the Rhine. Thus, the quartzite diminution rate attributed to the ancestral Potomac River is fully 60 times that determined by modern studies!

The contradiction grows even worse when one considers that the role of the ancestral Potomac River envisioned by Hack (1955) was to grind down the upland cobbles at the

\section{SED}

4, 363-428, 2012

\section{In plain sight: the Chesapeake Bay crater ejecta blanket}

D. L. Griscom

Title Page

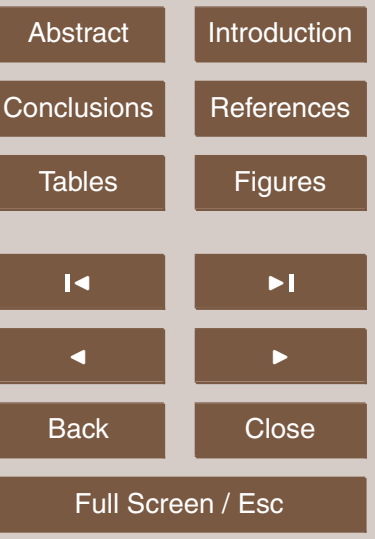

Printer-friendly Version

Interactive Discussion 
absolutely fantastic rate implied by Fig. $3 b$, while at the same time failing to cut a channel down to bed rock in the "soft easily eroded Coastal Plain sediments" - words used by Schlee (1957) to describe the substrate of the upland deposits.

Schlee (1957) extrapolated his fitted curve of Fig. $3 b$ to a modal cobble size of $5128 \mathrm{~mm}$ somewhere in an area $\sim 18$ to $30 \mathrm{~km}$ northwest of the U.S. Capitol Building. However, upon visiting this hypothetical "source area" (likely within the dashed circle in Fig. 3a) he found the petrology to comprise "granites, diorites, schists, gneisses, and quartzites of the Piedmont province," in sharp contrast to the coarser fractions of upland deposits, which he said "contain little or no gneiss, schist, diorite, or granite."

\subsection{The fluvial model fails}

Clearly the source of the quartzite component of the gravel member of the upland deposits was not nearby. Schlee (1957) pointed out that "Though generally unfossiliferous, a few of the pebbles display fossil brachiopod impressions which indicate a Devonian age.." Therefore, he suggested that "...the source rock was probably the Oriskany sandstone," but noted that the nearest outcrop of Oriskany Formation is $\sim 130 \mathrm{~km}$ distant from the upland gravels (extreme northwest in Fig. 2). Among the other possible sources of metaquartzites he considered, only the Cambrian-age Weverton Formation at $\sim 60 \mathrm{~km}$ (Catoctin Mountain, just east of the Blue Ridge in Fig. 2) had been "identified tentatively in the upland deposits."

But given the total absence of a trail of ever-larger quartzite boulders leading back to either of these two possible sources, Hack's (1955) fluvial model fails the central test of uniformitarian geology: We do not see today's rivers transporting cobbles over distances $\sim 60$ to $130 \mathrm{~km}$ before depositing the first one. Although such things may conceivably happen in the case of superfloods (Baker, 2002), this scenario would surely have resulted in total stripping of the soft coastal plain sediments before the deposition of the first cobble.

\section{SED}

4, 363-428, 2012

In plain sight: the Chesapeake Bay crater ejecta blanket

D. L. Griscom

\section{Title Page}

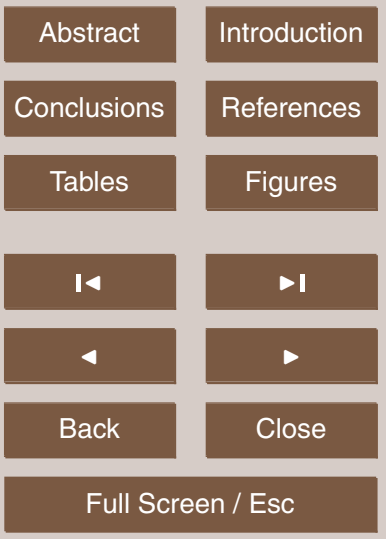

Printer-friendly Version

Interactive Discussion 
Moreover, even if there had been a nearby source of quartzite boulders, Hack's (1955) model imputed to the ancestral Potomac River is intrinsically improbable:

"... the ancestral Potomac flowed in soft sediments, less resistant to erosion than the gravelly bed load of the river. For this reason the river meandered across the 5 Coastal Plain, continually lowering its channel, it had a tendency to cut and erode the bank composed of Miocene sand more rapidly than the bank composed of gravel. As a result, in the Coastal Plain, the river has eroded a wide valley and kept it gently terraced and veneered with abandoned flood plain and channel deposits."

Now faced with the detailed similarity of the upland deposits in two widely separated 10 locations (Sect. 2), Hack's (1955) model of the ancestral Potomac would have to be extended also to the ancestral Rappahannock, York, and James Rivers (cf. Fig. 1). And the probability of all four of these rivers simultaneously performing such a "danse fantastique" would be calculated as the palpably low probability of Hack's (1955) model for the ancestral Potomac being correct raised to the fourth power.

\section{Upland deposits facies better explained as resulting from the impact}

\subsection{Impact geophysical arguments}

Schlee's (1957) gravel-size gradient summarized in Fig. 3 is better explained as being the result of atmospheric size sorting (Schultz and Gault, 1979) of interference-zone crater ejecta (Melosh, 1989) from the CBIS target area ...which is known to have included a $400 \mathrm{~m}$-deep unit consisting of "mainly lower Cretaceous to upper Eocene, poorly lithified, and mainly siliciclastic sedimentary rocks" (Koeberl et al., 1996). As will be justified in Sect. 4.2, this profound siliciclastic unit very likely included silt, pebbles, and cobbles of Paleozoic quartzite. After ejection from the crater, the gravel component would have been aerodynamically decelerated roughly in inverse proportion to particle size, resulting in the smallest pebbles dropping out closer in and the larger cobbles falling progressively farther away from the crater center. By contrast, the finest
SED

4, 363-428, 2012

In plain sight: the Chesapeake Bay crater ejecta blanket

D. L. Griscom

Title Page

Abstract Introduction

Conclusions References

Tables

Figures

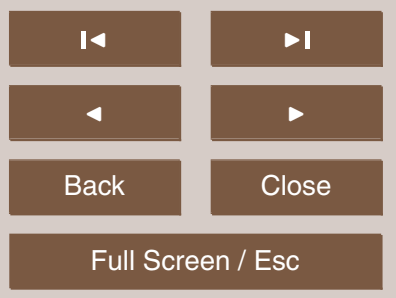

Printer-friendly Version

Interactive Discussion 
silt component is likely to have become entrained in turbulent clouds wherein it would have been transported by "a base-surge-type density current" (Melosh, 1989), which would have delayed its fallout relative to the gravels, thus emplacing the loam on top of the gravel - precisely as described to be the case for the upland deposits (Hack, 1955; 5 Schlee, 1957; Matthews et al., 1965; Goodwin and Johnson, 1970)!

Regarding Schlee's (1957) wavy "chocolate to ruddy brown" bands locally cementing the gravels, it should be noted that those $\sim 1 \mathrm{~cm}$-thick "wavy bands" are better described as wavy two-dimensional sheets. And in all cases the author has inspected, such sheets have been terminated by fresh conchoidal fractures (cf. examples in Fig. 4 and 10 the color photography of Griscom et al. (2003)) ...implying that they were originally parts of larger sheets that broke apart during and/or just prior to emplacement.

After investigating fully 98 locations, Schlee (1957) reported the largest "irregular mass" cemented by "fraction of an inch thick" bands "which parallel and transect the bedding at a low angle" to be only $\sim 1 \mathrm{~m}$ across (as opposed to tens meters across as 15 might be expected under the canonical notion that they were precipitated in situ from water solution). If, based on the observations of Griscom et al. (2003), it is assumed that all such "irregular masses" were not much thicker than the average pebbles and cobbles webbed together by those hard ferrihydrite-matrix sheets, then Schlee's (1957) largest object of this nature ( $\sim 1 \mathrm{~m}$ across) would have had an aspect ratio of $\sim 10$ to 1 .

20 And Melosh (1989) has pointed out that "At low speeds (up to a few hundred meters per second) the near-surface ejecta consist of spall plates. These plates are several to ten times broader than they are thick."

Melosh (1989) further instructs that spall plates "are the largest and least shocked fragments thrown out at any given velocity" but that they "contain so much elastic energy from the interfering stress waves that they themselves break up into smaller, Grady-Kipp fragments immediately upon ejection." Here, then, must lie the explanation for the ubiquitous fresh fracture surfaces on the $\sim \mathrm{cm}$-thick "chocolate to ruddy brown" sheets that weld together the "peanut-brittle-form" pebble-and-cobble clusters endemic to the upland deposits.

\section{SED}

4, 363-428, 2012

\section{In plain sight: the Chesapeake Bay crater ejecta blanket}

D. L. Griscom

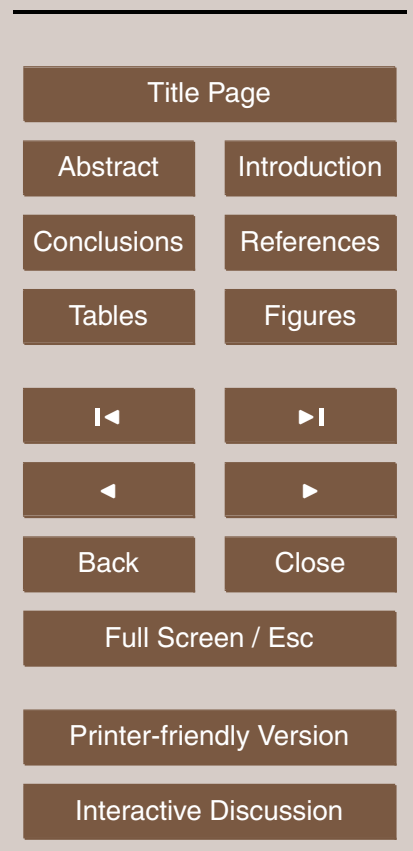


N. B. Griscom et al. (2003) have proposed in considerable detail an impact-based mechanism for the creation of such objects.

Finally, not mentioned above but certainly pertinent, is the fact that some exposures of the upland deposits include "extremely large boulders ranging from $\left(\sim 0.02 \mathrm{~m}^{3}\right)$ to

$5\left(3.7 \mathrm{~m}^{3}\right)$ " (Schlee, 1957). The author has inspected many such large boulders in upland areas south of Alexandria, Virginia. The conventional explanation for their existence, i.e. ice rafting, certainly must be called into question, given that the ice ages of the Quaternary are associated with sea-level lowstands as profound as $-140 \mathrm{~m}$ (e.g. Lambeck and Chappell, 2001). Under such conditions icebergs may not have gotten any closer 10 to the coastal uplands than the continental rise! Conversely, emplacement of large blocks ejected from impact craters on continental shelves should be virtually independent of both sea level and the topography of the terrains upon which they re-impact.

\subsection{Why quartzite cobbles must have been present in the target zone}

The Valley and Ridge Province stretching $\sim 115 \mathrm{~km}$ northwestward of the Great Val15 ley (beginning at the far northwest of Fig. 2) comprises a succession of $\sim 9$ anticlines and synclines, all of which include strata of durable Devonian (Oriskany) and Silurian (Tuscarora) sandstones (e.g. Means, 2010). Massanutten Mountain in the middle of the Great Valley (transected by the south-westward edge of Fig. 2) is capped with a syncline of "resistant Massanutten sandstone" (Frye, 1986). Therefore, it is no great 20 stretch of the imagination to suggest that the proto-Blue Ridge might originally have been a continuation of the Valley and Ridge Province. If this were true, it would have included anticlines of resistant Paleozoic quartzites stratigraphically above today's Skyline Drive.

In this scenario, the southeastward-facing alluvial fan of the proto-Blue Ridge in early Cretaceous times would have been rich in boulders, cobbles and pebbles of this quartzite. In fact, Schlee (1957) plotted the sorting-coefficients of the (almost exclusively quartzite) gravel component of the upland deposits of Southern Maryland as a

SED

4, 363-428, 2012

In plain sight: the Chesapeake Bay crater ejecta blanket

D. L. Griscom

Title Page

Abstract Introduction

Conclusions References

Tables Figures

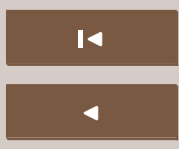

$>1$

Back

$\bullet$

Close

Full Screen / Esc

Printer-friendly Version

Interactive Discussion 
function of particle size, finding them to be a near perfect match to data for an alluvial fan as reported by Emery (1955) (Fig. 5).

Attal and Lavé (2006) established quartzite to be the most abrasion-resistant Himalayan rock in the Marsyandi River in Nepal, both by field observations and experi5 mental measurements in a circular flume. Their experimental mass loss per kilometer for 4-to-10-cm quartzite pebbles was just $0.15 \%$. In the field, they found quartzite cobbles in the size range 160 to $640 \mathrm{~mm}$ to comprise $\sim 33 \%$ of the bed load $\sim 200 \mathrm{~km}$ from the river's source, but only $\sim 3 \%$ of the bed load in the zone $\sim 32$ to $50 \mathrm{~km}$ from the source, where landslides are still delivering quartzite boulders directly into the river.

So on the basis of the modest assumptions that (i) the proto-Blue Ridge was indeed capped by durable quartzites and (ii) it was eroding 36 million years ago in a manner similar to that of the present-day Himalayas, it can be postdicted that there should have been abundant quartzite pebbles and cobbles in the target zone of the CBIS impactor ( $\sim 250 \mathrm{~km}$ southeast of the Blue Ridge), and a paucity of such pebbles and cobbles 15 closer to the source.

According to Poag (1997), the siliciclastic lower-Cretaceous unit in the CBIS target area was "mainly non-marine" - implying that the increasingly higher marine transgressions of the early Cretaceous (Fig. 6) must have been accompanied by increasingly larger terrigenous influxes toward the Atlantic basin, resulting in a prograding (or stationary) shoreline due to sediment delivery rates exceeding (or equaling) the rates at which the sea level was rising (e.g. Vail et al. 1977). These sediments could only have come from a disintegrating proto-Blue Ridge. Thus, the only rational way to account for the very existence of the quartzite gravels of the upland deposits is to postulate that the proto-Blue Ridge was indeed capped by the same Oriskany and Tuscarora quartzites

\section{SED}

4, 363-428, 2012

\section{In plain sight: the Chesapeake Bay crater ejecta blanket}

D. L. Griscom

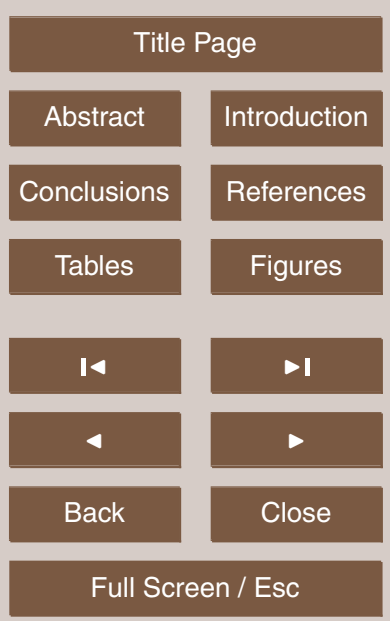

Printer-friendly Version

Interactive Discussion 


\subsection{New lithological data from Northern Virginia}

\subsubsection{Planar fracture statistics of upland quartzite gravel}

As a quasi-random sample of the coarser upland gravels in the author's former neighborhood of Hollin Hills, Fairfax County, Virginia, he investigated 214 quartzite pebbles

5 and cobbles already raked up by a neighbor (Fig. 7a). This neighbor likely suppressed smaller pebbles and possibly set aside larger cobbles, but at least this collection had no investigator-imposed biases. In particular, it was decided to count the number of fractured rocks in each size class. Then, since many of the samples were evidently fractured along two or more intersecting planes, the numbers of rocks with more than one non-parallel fractures were recorded separately from those singly fractured. Any non-parallel planar fracture running part way through any fragment of what was obviously once a well-rounded rock prior to the first fracture was counted as a "second fracture." (Commonly the first fracture had separated the specimen from the rest of the original rock.) However, any fractures that were parallel to the surface of the first complete fracture were not counted as second fractures, even though these occurred quite frequently. In all, only one rock exhibited the slightest evidence of post-fracture re-rounding, and that one was counted as not fractured. As histogrammed in Fig. 7b, $54.5 \%$ of the $32-64 \mathrm{~mm}$ fraction, $65 \%$ of the $64-128 \mathrm{~mm}$ fraction, and $57 \%$ of the 128-256 $\mathrm{mm}$ fraction exhibited at least one planar fracture.

20 The condition and location of these rocks (high prevalence of fresh planar fractures, zero evidence of re-rounding, and lying atop a flat $65 \mathrm{~m}$ a.s.l. clay plateau (described in Sect. 10.1)) are patently inconsistent with fluvial deposition.

\subsubsection{An unusual quartzite fracture facies}

Figure 7c exhibits a quartzite cobble discovered elsewhere in the same residential lot. 25 The fracture facies of this rock is reminiscent of the way in which glassy materials fracture under tensile stress: Defect-free fused-silica optical fibers $\sim 50$ to $500 \mu$ in diameter
SED

4, 363-428, 2012

In plain sight: the Chesapeake Bay crater ejecta blanket

D. L. Griscom

\section{Title Page}

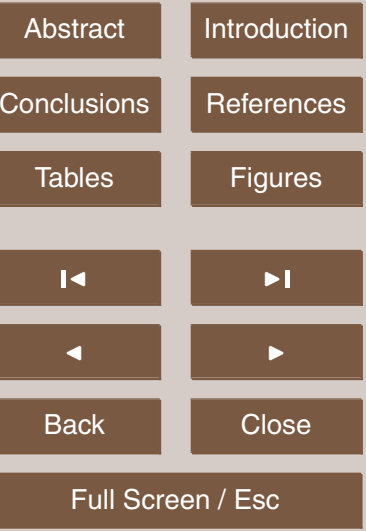

Printer-friendly Version

Interactive Discussion 
can survive up to 5 Giga Pascal tensile stress before fracturing, (e.g. Mecholsky, et al., 1974 and Brandt and Tressler, 1994) and when they do, a characteristic "mirror-misthackle" fracture surface is observed under a microscope, as cartooned on Fig. 7d. It seems reasonable to interpret the macroscopic fracture facies of this metaquartzite 5 rock as also being an indication of fracturing under extreme tensile stress, given the facts that (i) its fracture strength, like that of the fibers, is ultimately determined by the strength of silicon-oxygen bonds and (ii) metaquartzite is normally subject to "uneven, splintery to conchoidal fracture" (Chesterman and Loew, 1978).

While there does not seem to be a mist zone on the rock of Fig. 7c, the mirror and 10 hackle are unmistakable. Unlike any other part of this particular cobble, the "mirror" area exhibits vitreous luster and is so flat that a straight edge laid across it is within a fraction of a millimeter of the surface over the entire $7 \mathrm{~cm}$ width. In addition, there is an internal planar fracture sub-perpendicular to the "mirror" that runs $\sim 2 / 3$ of the way through the entire rock; its intersection with the mirror surface (indicated by arrows) parallels the semi-major axis of the ellipse roughly defining the mirror. It is conceivable that these unusual features resulted from two nearly orthogonal tensile waves having passed through this cobble, possibly at the same moment.

N. B. Tensile waves result when pressure waves impinge on a free surface. Thus, any upward propagating shock wave, such as those originated by subsurface explosions of hypervelocity impactors, upon reaching the surface of bed of sediments would return downward as a rarefaction wave "equal in strength but opposite in sign to the shock wave" (Melosh, 1989).

\section{Calculation of the CBIS ejecta blanket profile}

\subsection{Within minutes of the impact}

25 To aid in the search for ejecta deposits of degraded or buried terrestrial craters, it is helpful to have a quantitative notion of the size and morphology of the ejecta blanket
SED

4, 363-428, 2012

In plain sight: the Chesapeake Bay crater ejecta blanket

D. L. Griscom

Title Page

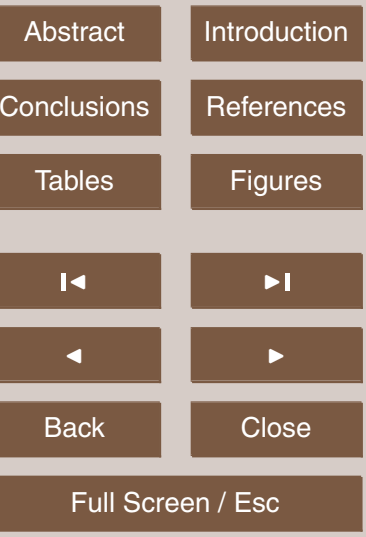

Printer-friendly Version

Interactive Discussion

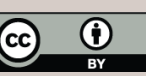


when it was first emplaced. An empirical rule has emerged from target-strengthgoverned explosion experiments (McGetchin et al., 1973), which by very good fortune turns out to be applicable as well to gravity-dominated impact craters of diameters ranging from $1.3 \mathrm{~km}$ to $436 \mathrm{~km}$ (Melosh, 1989). This rule states that the heights $h(r)$ of 5 ejecta blankets outside of the crater rim are roughly proportional to the negative third power of the radius $r$ from the crater center:

$h(r)=f(R) r^{-3}(r>R)$,

where $R$ is the final crater radius and the coefficient $f(R)$ depends on specific details of the crater in question (Melosh, 1989). The total volume of ejecta $V_{\mathrm{ej}}$ that came out un under a surface of revolution with the radial profile defined by Eq. (1) by integrating from $r=R$ and to $r=\infty$ :

$V_{\mathrm{ej}}=\int_{R}^{\infty} 2 \pi r \cdot h(r) d r=\int_{R}^{\infty} 2 \pi f(R) r^{-2} d r=\pi f(R) / R$

Whence, $f(R)=R V_{\mathrm{ej}} / \pi$. Thus, if one knows the final crater radius $R$ and the total 15 of $V_{\mathrm{ej}}$ fails to include the amount of substrate ripped up and incorporated into the ejecta blanket (Overbeck, 1975). Therefore, the present use of the amount of material ejected from the crater $V_{\text {ej }}$ (ignoring substrate incorporation) to approximate $V_{\text {ejectablanket }}$ yields only a lower limit for the actual value of $f(R)$, i.e. $f_{\min }(\mathrm{R})$.

Following the general procedures adopted by Warren et al. (1996) (of necessity including estimation of the size of the transient crater), a value of $V_{\mathrm{ej}}=4510 \mathrm{~km}^{3}$ was arrived at for the Chesapeake Bay crater. However, a similar number given by Poag (1997), $V_{\text {ej }}=4300 \mathrm{~km}^{3}$, is adopted for present purposes. The final crater radius $R=45 \mathrm{~km}$ was taken from the work of Koeberl et al. (1996) and Poag (1997). Thus, the factor needed to calculate the minimum thickness of the Chesapeake Bay crater ejecta blanket by use of Eq. (1) is:

$f_{\min }(45)=45 V_{\mathrm{ej}} / \pi=61600 \mathrm{~km}^{4}$.
SED

4, 363-428, 2012

\section{In plain sight: the} Chesapeake Bay crater ejecta blanket

D. L. Griscom

Title Page

\section{Abstract}

Introduction

Conclusions

Tables

References

\section{Figures}

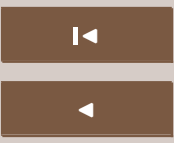

Back

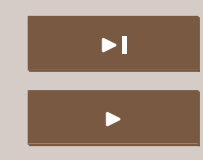

Close

Full Screen / Esc

Printer-friendly Version

Interactive Discussion 
Next, to lend "realism" to the ejecta-blanket plots based on Eq. (1), it was decided to include a profile representing the crater itself. For this purpose the crater was approximated as a cylindrical hole in the ground having a radius $R$ and a depth adjusted to make its capacity exactly equal to the excavated volume $V_{\mathrm{ej}}$. The depth calculated in 5 this way turns out to be identically equal to the height of the rim above the target surface. This cylindrical profile of Fig. 8 represents neither the transient crater nor of the final crater. However, it is much closer to the latter, neglecting principally the central uplift, the annular trough, and the local collapse of the final-crater rim - all features of the CBIS determined and illustrated by Koeberl et al. (1996), Poag (1997), and Gohn 10 et al. (2008).

In Fig. 8, the depth of the crystalline basement has been tuned to match the depth at which the USGS-NASA Langley Corehole at Hampton, Virginia, intercepted basement granite, $626.3 \mathrm{~m}$ (Horton et al., 2005), and the cartooned sedimentary units are roughly based on figures published by Koeberl et al. (1996) and Poag (1997). To add further 15 realism, it was decided the give the target surface a gentle seaward slope of $0.5 \mathrm{~m} \mathrm{~km}^{-1}$ - just about the same as the present day slope of the base of the upland deposits in Southern Maryland, as illustrated by Krantz and Powars (2000) and incorporated into Fig. 9.

Except for the range $r \cong 45 \pm 2 \mathrm{~km}$ where details the final crater rim are badly represented, the calculated profile of Fig. 8 for $r>R$ should paint a fairly accurate picture of the idealized lower-limit Chesapeake Bay crater ejecta blanket (neglecting anisotropic dunes, hummocks, ridges, rays, and added rip-up materials) when it was only a few minutes old.

\subsection{Details not expressed in the calculation}

\subsubsection{Seaward arc of the ejecta blanket}

Much of the ejecta launched the farthest seaward of the CBIS impact is very likely to have become fluidized by mixing with sea water in enhanced analogy with Martian
SED

4, 363-428, 2012

In plain sight: the Chesapeake Bay crater ejecta blanket

D. L. Griscom

Title Page

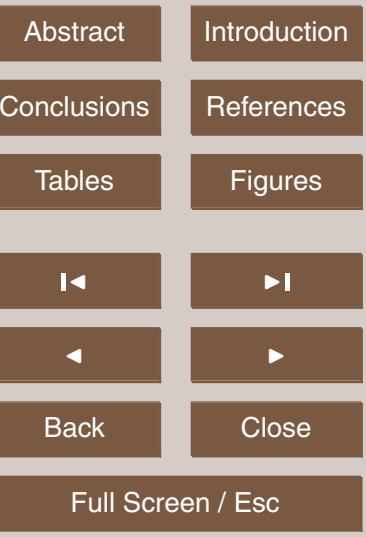

Printer-friendly Version

Interactive Discussion 
craters exhibiting fluidized ejecta blankets (Melosh, 1989). In consequence, the ejecta thrown out the farthest seaward might well have transported all the way into the Atlantic Basin in advance of the oceanic resurge, which has been determined by Horton et al. (2007) and Gohn et al. (2008) to have breached the seaward crater rim and 5 swept diachronous non-marine Cretaceous sediments back into the crater. However, "breaching" is different from total destruction. The ejecta blanket calculated here was emplaced by released energy equivalent to $\sim 2 \times 10^{7}$ megatons of TNT (Marcus et al., 2010), whereas the oceanic resurge carried only a tiny fraction of this energy and was subject to deflection by the gently rising slopes and gently curving circumferences of 10 the blanket.

\subsubsection{Landward arc of the ejecta blanket}

The volume of water initially landward of the impact point would have been locally comparable to the volume of the solid ejecta hurled landward $\left(\sim 2000 \mathrm{~km}^{3}\right)$ and, what is more, most of this water was very likely to have been blown away and/or vaporized in 15 the jetting stage of the impact. The jetting stage for a $6 \mathrm{~km}$-diameter comet arriving at $30 \mathrm{~km} \mathrm{~s}^{-1}$ and striking the Earth at the most probable angle of 45 degrees (Shoemaker, 1962) resulting in an $87 \mathrm{~km}$ diameter crater (Marcus et al., 2010) would have lasted only 0.28 second (Melosh, 1989), but according to Melosh (1989):

"The highest speed ejecta are thrown out during the earliest stage of impact crater20 ing, when the projectile first contacts the target." "...jets of highly shocked, melted or vaporized, material squirt into the adjacent open space at speeds usually faster than the projectile itself." "Oblique impacts may ...produce jets comparable in mass to the projectile."

Therefore, the landward-facing arc of the ejecta blanket should have experienced 25 negligible damage from returning ocean waves from the northwest and would have been shielded from the primary Atlantic resurge by the wider and deeper parts the seaward-facing arc. So in the author's view, much of the original ejecta blanket should have remained largely intact for a geologically substantial period of time, with its 383

\section{SED}

4, 363-428, 2012

In plain sight: the Chesapeake Bay crater ejecta blanket

D. L. Griscom

Title Page

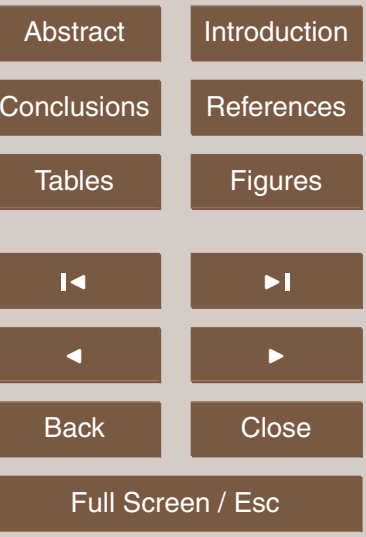

Printer-friendly Version

Interactive Discussion 
landward profile initially matching the left-hand side of the calculation of Fig. 8 after allowing for the collapse of the blanket rim in the range $r \cong 45 \pm 2 \mathrm{~km}$, while its the seaward arc might well have been battered down by the resurge to a level lower than the sea level at that time (believed to have been $\sim 150 \mathrm{~m}$ above present).

\section{Assessing the landward ejecta blanket}

\subsection{Elevation profiles of the Virginia Coastal Plane}

If it is assumed for the sake of argument that the upland deposits of Southern Maryland (Fig. 9) are truly Chesapeake Bay crater ejecta resting on a gently concave-upward series of offlapping clay terraces (possibly sculpted by the jetting phase of the impact), one wonders if there is any evidence of the same thing happening in Virginia. With the aim of seeking answers, Google Earth was employed to manually pick off the elevation profiles corresponding to the crater-centric radial and sub-radial transects defined in Fig. 10.

In Fig. 11 the calculated Chesapeake Bay crater ejecta blanket profile is again super15 posed on the present-day elevation profiles, again employing gently sloping bases to represent the uppermost coastal sediments upon which the ejecta likely re-impacted. However, this time the actual substrates for the upland deposits of Virginia are unknown to the author (in contrast to what is revealed in Fig. 9 to be true of Southern Maryland). The values $\sim 0.4 \mathrm{~m} \mathrm{~km}^{-1}$ selected for the slopes of the dashed lines were based on the operating assumptions that the Bacons Castle Formation (BCF) may be $\sim 10$ to $20 \mathrm{~m}$ deep and that, like the upland deposits, it too may rest on a gently sloping base of older clay sediments.

However, in contrast to the gentle nearly constant $0.56 \mathrm{~m} \mathrm{~km}^{-1}$ slope of the base of the upland deposits in Southern Maryland evident in Fig. 9, it is seen in Figs. 11b and $12 \mathrm{a}$ and $12 \mathrm{~b}$ that in southeast Virginia the upland deposits commonly blanket Vshaped valleys running nearly perpendicular to transects passing through or near the
SED

4, 363-428, 2012

\section{In plain sight: the \\ Chesapeake Bay \\ crater ejecta blanket}

D. L. Griscom

Title Page

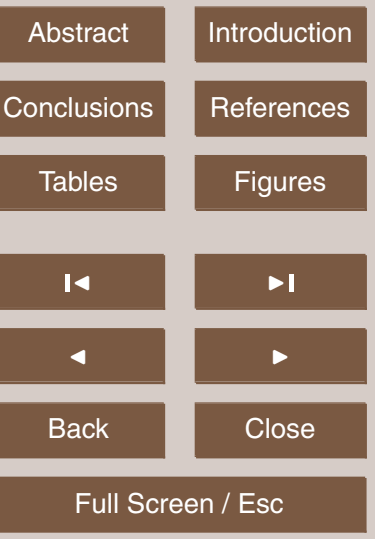

Printer-friendly Version

Interactive Discussion 
crater center. The V-shaped valleys decorated with upland deposits possess craterfacing slopes ranging from $4 \mathrm{~m} \mathrm{~km}^{-1}$ on the York-Rappahannock peninsula (Fig. 11b) to $6.3 \mathrm{~m} \mathrm{~km}^{-1}$ just east of Richmond, Virginia (Fig. 12a). Moreover, as seen in Fig. 13b, the upland deposits south and west of Richmond overlie a tight cluster of locations sep5 arated vertically by as much as $70 \mathrm{~m}$ ! Taken together, these observations prove these upland deposits have to have been laid down directly on top of pre-existing topography having these particular slopes and elevations. This could easily have happened simultaneously in the case of ballistic emplacement, whereas one's educated sense of the probability of this having resulted from a protracted series of fluvial episodes may be even lower than has been expressed in Sect. 3.2.

\subsection{Bacons Castle Formation reinterpreted}

Is the BCF crater ejecta? Figs. 11 and 12 give no clue, except possibly for the seaward rising elevation profiles of the central and northerly sections in Fig. 12b, which are unexpected for a coastal-plain terrace but consistent with their being a vestiges of 5 an originally higher ejecta blanket as calculated in Sect. 4.1 and illustrated in Fig. 8. But such evidence is purely circumstantial. By contrast, Wentworth (1928) described the main distinction between the "Brandywine gravels", i.e. the eastern-Virginia upland deposits, and "the lower, younger gravels", i.e. the BCF, as being the absence of striated boulders and cobbles in the higher level gravels and the presence of such striated boulders and cobbles in the lower level gravels.

\subsubsection{Significance of striated rocks}

Relatively rare striated rocks have been found in ejecta outcrops associated with the buried Chicxulub crater (65 Ma, $180 \mathrm{~km}$ diameter, Yucatán Peninsula, México) slightly inside of 5 crater radii (Ocampo et al., 1996; Pope et al., 1999; King and Petruny, 2003). 25 According to King and Petruny (2003), "King et al. (1997) interpreted facets, polish, and striations as representing effects of hypervelocity interactions among clasts during
SED

4, 363-428, 2012

In plain sight: the

Chesapeake Bay crater ejecta blanket

D. L. Griscom

Title Page

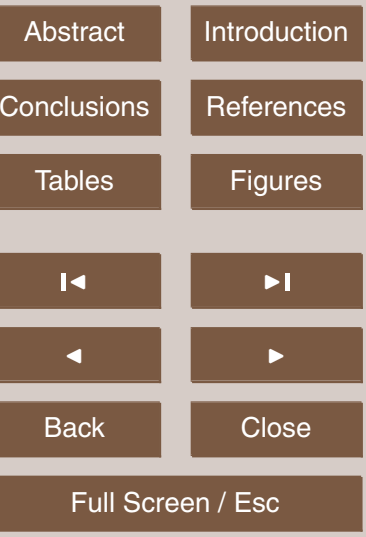

Printer-friendly Version

Interactive Discussion 
(internal-to-the-crater) ballistic excavation and ejection." If this explanation should be correct, then the following implication would apply: Because excavation-flow crater ejecta are volumetrically much greater than, and are ejected at much lower speeds than are interference-zone ejecta (Melosh, 1989), striated rocks should be an increas5 ingly common occurrence in ejecta blankets as the crater rim is approached from great distance along a radial. And this is essentially what Wentworth (1928) reported to be the case for a generalized CBIS-centric transect, i.e. beginning somewhere in the upland deposits (no striations) and crossing into the BCF (abundant striations) in the general direction of the CBIS (cf. Fig. 1).

\subsubsection{Additional evidence that the Bacons Castle Formation comprises CBIS ejecta}

The following passage penned by Poag (1997) suggests the outside-the-crater BCF and the in-crater CBIS sediments may constitute a single lithofacies:

"Above the lower Miocene unit (referring to canonical age of the outside-the-crater 15 Calvert Formation), coarser siliciclastic units of middle Miocene to Quaternary age (referring to canonical ages ranging from that assigned the upland deposits to that assigned to the latest BCF) are widespread throughout southeastern Virginia. Outside the crater, these units thicken gradually as they dip gently to the southeast. But where they cross the crater rim, the units abruptly thicken (moderately to slightly) and sag into 20 the annular trough. The same units sag and thicken even more where they overly the inner basin."

This passage essentially states that (i) the BCF thickens as it approaches the crater rim from the outside - just as does the calculated ejecta blanket of Fig. 8 - and (ii) it surmounts the crater rim and then sags into the crater interior - matching a more realistic version of Fig. 8 wherein the unphysically vertical wall internal to the calculated ejecta blanket is allowed to partially collapse into the crater interior. Thus, Poag's (1997) description above is tantamount to stating that the BCF is contiguous with the upper in-crater Calvert Formation - the only difference being that the lower part of the
SED

4, 363-428, 2012

In plain sight: the Chesapeake Bay crater ejecta blanket

D. L. Griscom

Title Page

Abstract

Introduction

Conclusions

References

Tables

Figures

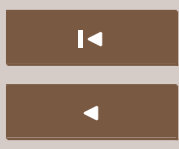

$\Delta$

Back

Close

Full Screen / Esc

Printer-friendly Version

Interactive Discussion 
in-crater Calvert is fossiliferous, whereas the BCF "is lacking in usable fossils or other datable material" (Hobbs, 2009) ....as is also the upper part of the in-crater Calvert (Poag, 1997).

\subsubsection{Virtually null fossil record present in impact ejecta}

5 Impact-crater ejecta are generally fossil-free, even if the target materials were fossiliferous, because preexisting fossils are normally pulverized by the high-pressure shock waves generated by the impact. It is likely that the only exceptions involve very-nearsurface interference-zone ejecta, where the maximum pressure is reduced to "a fraction of the free shock pressure" (Melosh, 1989). For example, it is entirely possible that

10 the "tropical" fossil discovered by Schlee (1957) (Sect. 2.3.1) was actually living in the "hothouse" interference zone of CBIS impactor 35.4 m.y. ago (rather than having been carried up north from Florida and "buried by Indians" (Schlee, 1957).

\section{Early post-impact in-crater processes and events}

\subsection{Ejecta blanket as sole source of post-impact in-crater sediments}

The prolonged existence of a substantial fraction of the original CBIS ejecta blanket inferred in Sect. 5.2.2 has a corollary: During its existence, it would have been the sole source, via inward mass wasting, of the post-Exmore-breccia lithologic sequences accumulated on the crater floor (cf. Fig. 14). Any terrigenous influxes from the Piedmont would have been deflected by the landward arc (and totally locked out so long as it remained above sea level), and it is very unlikely that any such sediments would ever have entered from the ocean side ...even if the original seaward arc of the ejecta blanket had been totally removed by the oceanic resurge, which is deemed unlikely (cf. Sect. 5.2.1).

\section{SED}

4, 363-428, 2012

\section{In plain sight: the Chesapeake Bay crater ejecta blanket \\ D. L. Griscom}

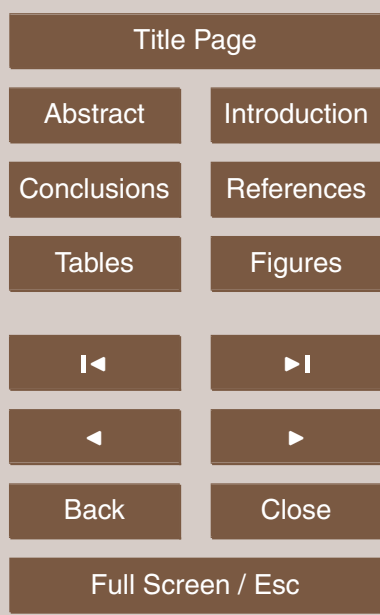

Printer-friendly Version

Interactive Discussion 


\subsection{Effects of the ejecta blanket on marine species}

The two different foraminiferal assemblages found in the lithologically-indistinguishable in-crater Chickahominy and overlying Calvert Formations (Poag and Auby, 1995; Poag and Commeau, 1995; Poag, 1997) must have found ways to get inside the crater-

5 encircling ejecta blanket at different times. Quite likely the Chickahominy assemblage of planktonic foraminifera comprised pelagic species that entered the crater through a gap in the seaward face of the ejecta blanket (cf. Sect. 5.2) when the sea depth above the crater floor was still $\geq 400 \mathrm{~m}$. By contrast, the in-crater Calvert planktonic foraminifera are likely to have been neritic species, given their presence at $\sim 40 \mathrm{~m}$

10 above present sea level in the outside-the-crater Calvert core at Haynesville (e.g. Poag (1997)). Therefore, the latter assemblage may have arrived after the sea level - and possibly the sea temperature (cf. Sect. 7.3) - had dropped considerably. Either or both of these factors could explain the disappearance of the Chickahominy assemblage at that point, which is presumed to be pelagic on the basis that that 8 of the planktonic 15 foraminiferal species found there were also found in the DSDP 612 core (Poag and Auby, 1995, Poag, 1997). Otherwise, the heat released hydrothermally from the initially molten rock below the crater floor might well have extended the lives of the in-crater neritic species for as long as 1 m.y. after the impact (Steiner, 1996) despite the onset of global cooling only 200 k.y. later (cf. Sect. 7.3.1).

20 Notably, the in-crater-Calvert planktonic foraminifera go extinct (and are not replaced) midway up Calvert Formation segment of the Kiptopeke core (Poag and Auby, 1995; Poag and Commeau, 1995; Poag, 1997), implying a prolonged period of lithic sedimentation during which no measurable populations of planktonic foraminifera of any sort lived in waters above. During this sterile period, apparently lasting all the way 25 to present time (cf. Sect. 6.2.2), the immediately adjacent updip arc of the surviving ejecta blanket (aka the BCF) would have seamlessly joined the crater infill, thus jointly comprising a single (biologically-sterile) lithofaces, as per Poag's (1997) description reproduced in Sect. 6.2.2.

\section{SED}

4, 363-428, 2012

\section{In plain sight: the Chesapeake Bay crater ejecta blanket}

D. L. Griscom

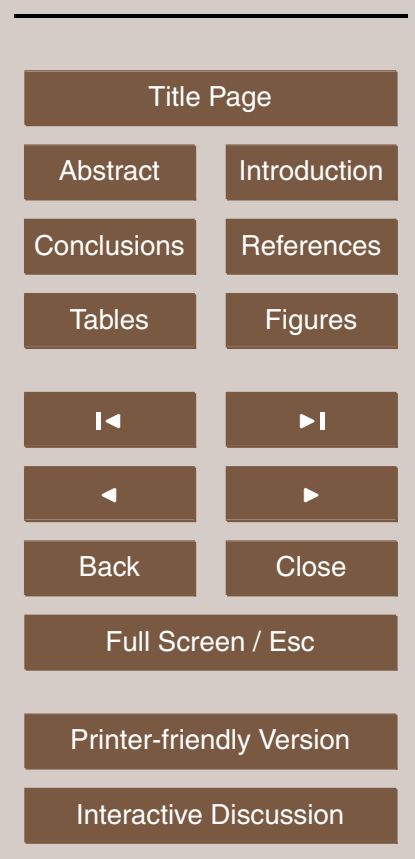




\subsection{Eustatic sea levels, glaciations, and river courses}

At the time of the CBIS impact (35.4 Ma) the local sea level is generally agreed to have been $\sim 150 \mathrm{~m}$ above present, and indeed the eustatic sea level had been this high or higher for most of the preceding $\sim 70$ m.y. (Fig. 6). And for the previous 200 m.y., the

5 Earth had no ice caps. Then suddenly all of this changed $\sim 1.4$ m.y. after the CBIS impact with the sudden onset (not the peak) of the Oi-1glaciation (Pälike et al., 2006) and the advance of the Antarctic ice sheets, which first appeared around the time of the impact (Zachos et al., 2001).

\subsubsection{Possible mechanisms of the hothouse-to-icehouse transition}

10 Fawcett and Boslough (2002) have made the case that late-Eocene/early-Oligocene cooling event might have been the result of the Chesapeake Bay impact - or the contemporaneous impact in Siberia that created the $100 \mathrm{~km}$-diameter Popigai crater, e.g. (Bottomley et al., 1997) - inserting sufficient material into Earth orbit to create a transient Saturn-like ring, which during its lifetime would have shadowed and severely 15 cooled the tropics and subtropics and, according to Fawcett and Boslough's (2002) state-of-the-art climate calculations, it might have been the trigger for the ice-cap formation and continental glaciations inferred by Zachos et al. (2001), Pälike et al., (2006), and others.

Apropos, Pälike et al. (2006) recorded an astronomically-age-calibrated, high20 resolution climate proxy record of the entire Oligocene from one continuous Pacific Ocean core. They then tried two different "carbon cycle box models" combined with their astronomical forcing time series in an effort to reproduce the Oi-1 glaciation just as it was observed in their records. To investigate the possible response of the oceanic carbonate ion, Pälike et al. (2006) combined astronomical forcing terms with the "more sophisticated model" of Walker and Kasting (1992), thereby forcing "...global temperature by the annual and mean monthly insolation $\left(65^{\circ} \mathrm{N}\right)$ and the carbon burial by mean monthly summer insolation." By these means they were "...able to reproduce
SED

4, 363-428, 2012

In plain sight: the Chesapeake Bay crater ejecta blanket

D. L. Griscom

Title Page

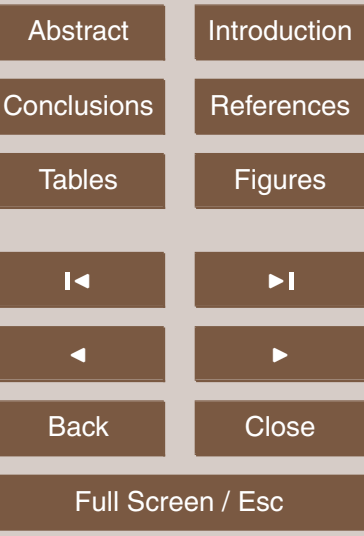

Printer-friendly Version

Interactive Discussion 
a strong eccentricity-driven response in the modeled lysocline depth (for which their sedimentary $\mathrm{CaCO}_{3}$ record served as a proxy) from a forcing term that is dominated by climatic precession." Pälike et al. (2006) accomplished this result by postulating a major sequestration of atmospheric $\mathrm{CO}_{2}$ beginning at $35.2 \mathrm{Ma}$ and ramping up to $15 \%$

$5 \sim 125$ k.y. later. They characterized this postulate as "a possible mechanism to explain the record across the E-O transition."

In principle one could postulate a different "possible mechanism" for the very same result. The author proposes here that $35.4 \mathrm{Ma}-35.2 \mathrm{Ma}=200 \mathrm{k} . \mathrm{y}$. may have been the length of time it took for Fawcett and Boslough's (2002) randomly Earth-orbiting 10 crater ejecta to collapse into a partially-earth-shadowing torus, which would then have proceeded to evolve into a true ring over the next $\sim 125 \mathrm{k} . \mathrm{y}$. In this case, the insolation would have been reduced due to the rapidly-formed ring shadow, rather than the sudden burial of a lot of $\mathrm{CO}_{2}$ via mechanism or mechanisms unknown.

\subsubsection{Post-impact evolution of the Virginia's east-coast rivers}

Likely influenced by the glaciation, the eustatic sea level regressed to nearly presentday level within 2 m.y. (Hallam, 1984) or 5.4 m.y. (Vail and Mitchum, 1979) (Fig. 6), thereby permitting the rivers flowing southeastward of the proto-Blue Ridge to begin searching anew for their channels on the Piedmont. Frye (1986), writing at a time before the discovery of the CBIS, remarked that "Geologists interpret some of the eastern

20 Piedmont topography as exhumed from a cover of sediments because some stream patterns otherwise make no sense. Many present-day streams flow near but not in bedrock channels." Now that the CBIS has been discovered, the sediments that Frye (1986) refers to here might well be interpreted as being part of its ejecta blanket.

Meanwhile, down on the Coastal Plain it is seen in Fig. 11b (small black squares) 25 that the North Anna and Mattaponi Rivers are presently flowing perpendicular to the southerly-most transect of grouping B of Fig. 10, i.e. circumferential to the CBIS. Likewise, for the James and Chickahominy Rivers in Fig. 12a, southerly-most transect of grouping $\mathrm{C}$. And the same thing again for the Nottoway and Blackwater Rivers in
SED

4, 363-428, 2012

In plain sight: the Chesapeake Bay crater ejecta blanket

D. L. Griscom

Title Page

Abstract

Introduction

Conclusions

References

Tables

Figures

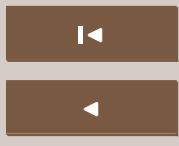

$\Delta$

Back

Full Screen / Esc

Printer-friendly Version

Interactive Discussion 
Fig. 12b, southerly-most transect of grouping D. Of course, most of today's rivers do not flow very far circumferentially before turning in the direction of the crater. The exception is the Nottoway River, which follows a $115 \mathrm{~km}$ radius for fully $60 \mathrm{~km}$ (cf. Fig. 1).

Note in Fig. 12a that a V-shaped valley coincident with the mouth of the Chicka5 hominy River (except for a $\sim 7-8 \mathrm{~m}$ rise in the middle) extends all the way across the James-York peninsula where it directly faces the mouth of the Mattaponi River on the York-Rappahannock peninsula (Fig. 11b), which is there flowing in the same circumferential direction. It is proposed here that this groove, extending across one and a half eastern-Virginia peninsulas, bears the imprint of a paleochannel (dashed arc in 10 Fig. 15a) of the ancestral York River (defined as beginning at the confluence of the Pamunkey and Mattaponi Rivers) dating to the period when it was still unable to breach the landward arc of the Chesapeake Bay ejecta blanket.

Because all six of the rivers in Figs. 11 and 12 happen to be moving in the counterclockwise sense where they intersect one of the transects of Fig. 10, one might be 15 tempted to attribute this fact to the Coriolis force acting on the southeastward flowing rivers. However, there is a much more likely explanation: an impenetrable radial barrier on the York-Rappahannock peninsula. Recalling that calculated ejecta-blanket profile of Sect. 5.1 neglects dunes, hummocks, ridges, rays, and substrate rip-up additions, one must admit to the possibility of an extra-deep ejecta deposit running up one or more of the peninsulas radial to the crater center.

The Dragon Run watershed (Fig. 15a) (Dragon Run Steering Committee, 2003) is a raised-rim depression, which evidently has never once during its existence allowed a major river to enter it from any point of the compass - a true oddity, given the canonical view that the upland deposits and BCF of the M-ACP were all emplaced within the 25 past $\sim 5 \mathrm{~m}$.y. by rivers slithering sidewise like snakes across soft coastal clay terraces, gently spreading their bed-loads uniformly, while never cutting channels down to bed rock (Sect. 3.2). At Dragon Run, the canonical view would need to credit the rivers with an additional ability: creating levees that arrested their own slithering.
SED

4, 363-428, 2012

In plain sight: the Chesapeake Bay crater ejecta blanket

D. L. Griscom

Title Page

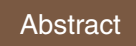

Introduction

Conclusions

References

Tables

Figures

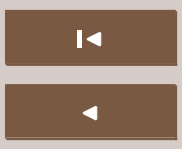

Back

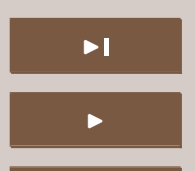

Close

Full Screen / Esc

Printer-friendly Version

Interactive Discussion 


\subsubsection{Putting aside uniformitarian geology in favor of the geology of impact cratering}

It is seen in Fig. 15a that the Dragon Run watershed is almost perfectly radial to the center of the Chesapeake Bay crater, and its outline looks as though it could be decom5 posed into a sequence overlapping of ellipses - very similar to the string of secondary craters of the lunar crater Copernicus reproduced in Fig. 15b.

Melosh (1989) states: "Nearly every large crater or basin seems to have one or more especially prominent radial troughs extending from the rim out to nearly one crater diameter" ...very close to the relationship that Dragon Run bears to the CBIS.

10 And he continues: "Originally thought to be tectonic features because of their often impressively straight walls, it is now believed that they are created by lines of coalescing secondary craters..."

\section{The Shirley Formation reinterpreted}

Poag (1997) remarks:

15 "The modern topography of the Chesapeake Bay region also appears to reflect the buried crater's influence (Peebles, 1984; Mixon, 1985; Mixon et al., 1989). For example, the middle Pleistocene-upper Pleistocene contact approximates the position of the Suffolk scarp, a feature of 11-22 m relief, which parallels the western rim of the crater."

In essence, the foregoing statement implicitly asserts that a buried crater somehow exerts structural control over surface features $\sim 34$ m.y. younger. Whereas it seems far more reasonable to infer that the Suffolk scarp is a durable, on-the-present-day-surface remnant of the original crater rim. Supporting the latter view, the Shirley Formation, of which the Suffolk scarp is only a small part (e.g. Peebles et al., 1984; Hobbs, 2009), is known to surround much of the CBIS and to sag into the crater wherever it touches the rim (e.g. Peebles et al., 1984; Frye, 1986). This includes on the Delmarva Peninsula where externally the Shirley Formation comprises the Ames Ridge, almost perfectly radial to the crater center!

SED

4, 363-428, 2012

In plain sight: the Chesapeake Bay crater ejecta blanket

D. L. Griscom

Title Page

Abstract

Introduction

Conclusions

References

Tables

Figures

14

- I

4

Back

Close

Full Screen / Esc

Printer-friendly Version

Interactive Discussion 
Peebles et al. (1984) state that "At the base of the Shirley formation there is a discontinuous pebbly to bouldery sand. The pebbles, cobbles and boulders range from well-rounded to angular and were derived from rocks of the Piedmont, Blue Ridge, and Valley and Ridge provinces. The largest clasts in these deposits are 5 feet in diameter."

$5 \quad$ As argued in Sect. 3.2, rivers cannot transport boulders very far - certainly not 5foot-diameter ones from as far away as the Blue Ridge all the way to the Delmarva Peninsula - much less from the Valley and Ridge province beyond the Blue Ridge (northwest edge of Fig. 2). Moreover, any boulders transported any distance at all by rivers would not remain angular. Therefore, by process of elimination, the boulders 10 at the base of the Shirley Formation must be CBIS ejecta consisting of target-zone basement rocks - lithological relatives of basement rocks previously recognized as such only in outcrops in the Piedmont, Blue Ridge, and Valley and Ridge Provinces.

Apropos, Crawford's (2002) computer-modeled time evolution of Chesapeake Bay impact shows materials being excavated from basement depths $\sim 2 \mathrm{~km}$ during the formation of the transient crater. These materials became the primary constituents of the expanding ejecta curtain from which fragments rained out continuously well beyond the final crater rim (cf. Melosh, 1989), easily reaching as far as the Shirley Formation outcrops mapped along river valleys landward of the CBIS (e.g. Peebles et al., 1984; Hobbs, 2009).

\section{What is agreed upon and what is not}

\subsection{Crater characteristics}

There can be no disagreement with the discoveries of the interior nature of the CBIS as elucidated by Poag et al. (1994), Poag and Aubry (1995), Koeberl et al. (1996), Poag (1997), Powars (2000), Poag et al. (2004), Horton et al. (2005, 2007), Gohn et al. (2008) and others. Rather, the prime bone of contention appears to concern the nature of the CBIS ejecta blanket:

\section{SED}

4, 363-428, 2012

In plain sight: the Chesapeake Bay crater ejecta blanket

D. L. Griscom

Title Page

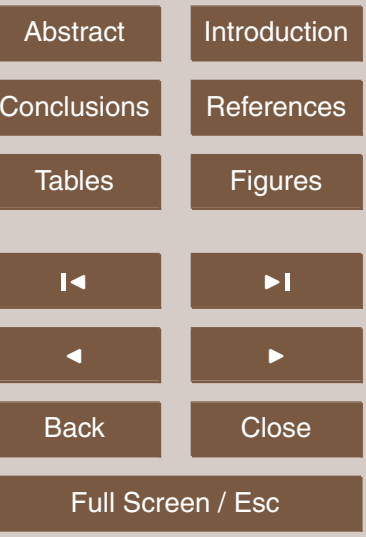

Printer-friendly Version

Interactive Discussion 
Claiming guidance from the writings of several cited impact-geologic authorities including Melosh (1989), Poag (1997) asserts that "...much of the coarsest debris ejected from the crater fell back into the excavation. Intermediate-size debris formed an irregularly distributed, continuous ejecta blanket surrounding the crater rim to a maximum 5 radial distance of $\sim 55 \mathrm{~km}$."

In stark contrast, the author's reading of Melosh's (1989) monograph on impact cratering instructed and inspired the minimum-height ejecta-blanket calculation of Fig. 8, which is $\sim 600 \mathrm{~m}$ high at the final crater rim and tapers to depths $\sim 10 \mathrm{~m}$ at a radial distances from the crater center $\sim 200 \mathrm{~km}$ (cf. Fig. 9). Ironically, this calculation (Sect. 4.1) 10 is normalized to the amount of material ejected from the crater as calculated by Poag (1997).

\subsection{Diachronisms}

For convenience in the following discussion, the high-elevation (up to $+78 \mathrm{~m}$ ) outsidethe-crater Calvert Formation - plus the overlying Choptank and St. Marys Formations of Fig. 9 - will be termed simply "Calvert l" and the low-elevation (no higher than $-33 \mathrm{~m}$ ) in-crater Calvert Formation will be denoted "Calvert II." These two Calverts are certainly diachronous, because their planktonic foraminiferal species are similar (23 species in common) but not identical (possessing 11 and 19 differing species, respectively) (Poag and Aubry, 1995; Poag and Commeau, 1995; Poag, 1997). There can be no dispute 20 on this.

Figure 14 schematically illustrates the two conceivable, but immensely different, diachronisms of Calverts I and II that must be decided between. For reasons to be reviewed below, the author is confident that the model represented by the red dashed isochron is correct. The white dashed isochron is a symbolic representation of the canonical view that both Calverts are of early Miocene age. That is, the placement of the white dashed curve in Fig. 14 is solely to make the point that, although certainly diachronous across a non-zero time interval, in the canonical view Calverts I and
SED

4, 363-428, 2012

In plain sight: the Chesapeake Bay crater ejecta blanket

D. L. Griscom

Title Page

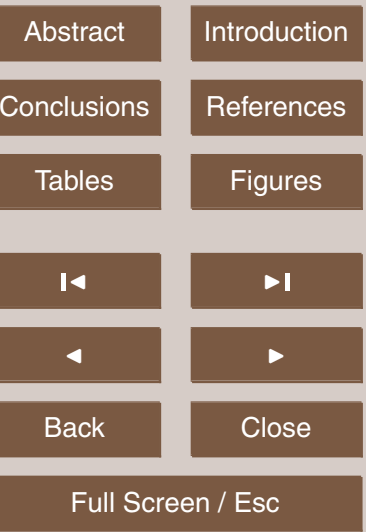

Printer-friendly Version

Interactive Discussion 
Il time-travel in tandem from the moment of the emplacement of the Chickahominy Formation as far into the future as $19 \mathrm{~m}$.y. (early/middle Miocene).

The (in-crater) Calvert II as defined here is stratigraphically above the Chickahominy Formation, separated by 4 unconformities spanning $\sim 30 \mathrm{~m}$ and 2 unconformities span5 ning $\sim 3 \mathrm{~m}$ in the Exmore and Kiptopeke cores, respectively (Poag and Aubry, 1995; Poag and Commeau, 1995, and Poag, 1997). These authors' charts show extinctions of Chickahominy planktonic foraminifera occurring mostly at the lowest unconformity and first appearances of Calvert species at the uppermost one. Their assignment of these unconformities to hiatuses adding up to $\sim 13$ to 19 m.y. tacitly implies a belief that 10 the foraminiferal turnover above the Chickahominy Formation was associated with a massive erosional event or prolonged cessation of deposition.

To the contrary, it is argued in Sects. 5.2.2, 7.1, 7.2, and 7.3.1 that for a geologically significant period of time after the impact, infilling of the crater resulted solely from inward mass wasting of the surrounding ejecta blanket, a process that would likely 15 have been speeded up by direct ocean-wave attack and slowed down during offlap events (cf. Sect. 9.3). However, deposition would never completely stop, nor could there be any erosional hiatuses, so long as the crater was not first filled to the top - something that Poag (1997) says never happened. Therefore, the unconformities and foraminiferal turnover recorded by Poag and Aubry (1995), Poag and Commeau (1995), and Poag (1997) almost certainly occurred within $\sim 1$ m.y. of the impact as the results of one or more of brief sea-level regressions (cf. Sect. 9.3) in combination with a major global cooling event, which may well have "ramped up" in the time interval 200 to $325 \mathrm{k} . y$. after the CBIS impact (cf. Sect. 7.3.1). As a corollary, the outside-the-crater Calvert I (containing 23 foraminiferal species in common with the in-crater Calvert II) was almost certainly emplaced within a few $100 \mathrm{k} . \mathrm{y}$. before the time of the impact, since those of Calvert II went extinct while still isolated inside the walls of the ejecta blanket (cf. Sect. 7.2).

\section{SED}

4, 363-428, 2012

\section{In plain sight: the Chesapeake Bay crater ejecta blanket}

D. L. Griscom

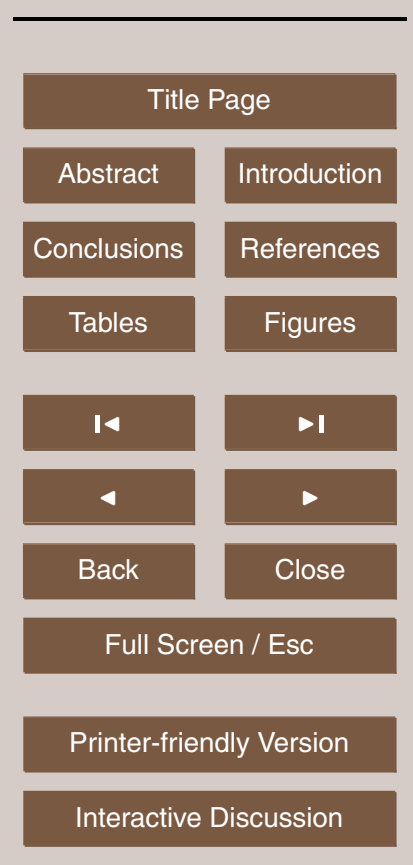




\subsection{Eustatic sea levels, offlap effects, and formations armored by CBIS ejecta}

It is clear from Fig. 6 that a major (1st order) marine regression took place either 2 m.y. after the impact (Hallam, 1984) or 5.4 m.y. afterwards (Vail and Mitchum, 1979), with the latter timing preferred due to the demonstrated success of the sequence5 stratigraphic system devised by Vail et al. (1977), Haq et al. (1987), and others. However, the latter authors considered only 1st, 2nd, and 3rd order sea-level cycles, whereas several fluctuations related to higher order cycles could have, and likely did, occur between the time of the impact and $30 \mathrm{Ma}$. Specifically, the glacio-eustacy-based 5th and 6th order cycles are respectively capable of one 100 -to-130 m regression per $10 \sim 100$ k.y. and one 30-to-100 $\mathrm{m}$ regression per 40 k.y. (Carter, 1998).

Of course, due to local subsidence or uplift, regional changes in sea level do not necessarily replicate eustasy. However, there exists independent evidence that the early/late-Oligocene eustatic sea-level offlap "retrodicted" by Vail and Mitchum (1979) (Fig. 6) strongly affected the M-ACP: Miller et al. (1990) carried out magnetostrati15 graphic and Sr-isotope studies of a deep borehole on the New Jersey Coastal Plain with the object of improving stratigraphic control for Eocene and Oligocene sediments on the continental shelf. Of particular relevance to the present discussion, they interpreted a discontinuity in their ${ }^{87} \mathrm{Sr}^{86} \mathrm{Sr}$-age-versus-core-depth plot as "a physical unconformity" and concluded that "the hiatus associated with this unconformity occurred between 35 and 28 m.y. ago."

Such a long period of sub-aerial erosion could well have resulted in the sweeping away of virtually all loose clays, silts, sands, and gravels deposited on the U.S. Middle-Atlantic continental shelf between the time of the impact (35.4 Ma) and $28 \mathrm{Ma}$, excluding the contents of the crater - which could not have been touched by sub-aerial 25 erosion unless and until it was first filled to the top, whereas Poag (1997) states that the crater "never completely filled with postimpact sediments."

Furthermore, there is a another CBIS-related aspect to this scenario: Some preimpact coastal-plain formations comprising similar, but perhaps more-compacted clays,

\section{SED}

4, 363-428, 2012

\section{In plain sight: the Chesapeake Bay crater ejecta blanket}

D. L. Griscom

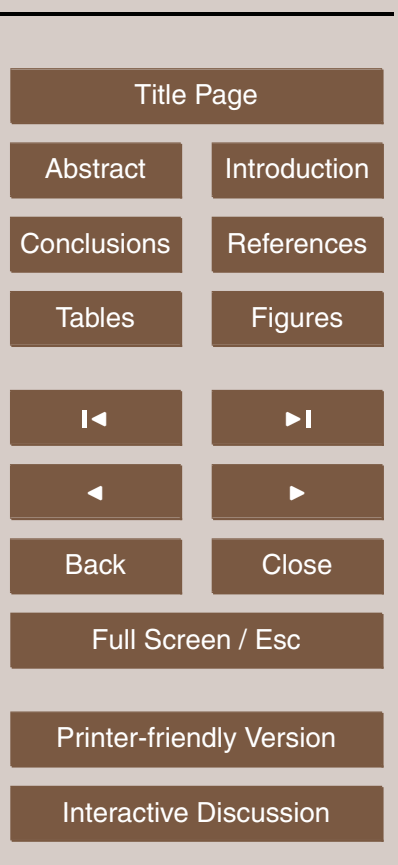


silts, sands, and gravels that had become capped by a bilayer of heavy gravel overlain by a highly coherent quartz-silt loam possessing the resistant properties of the upland deposits mentioned in Sect. 2.1 would have been eroded mainly by inefficient lateral attacks during the offlap event and subsequent marine transgressions. And be5 cause the upland deposits cannot have been emplaced by rivers (Sects. 3.2 and 6.1), whereas they can have been emplaced by impact-geologic processes (Sects. 4.1 and 6.2 ), they can only be interpreted as crater ejecta. As a corollary, all present-day formations blanketed by upland deposits equate to CBIS-ejecta-armored formations of late-Eocene age - not Miocene, as canonically believed.

10 Nevertheless, this arguably proven fact has not been publicly discussed by anyone other than the author, thus leaving "formally undecided" the question of whether Calverts I and II belong to the late-Eocene or the middle-Miocene.

\section{$9.4{ }^{87} \mathrm{Sr}^{86} \mathrm{Sr}$ dating of CBIS in-fill}

The only data that seriously appear to invalidate the author's conclusions are dates assigned to post-impact sedimentary infillings of the CBIS in the past $35.4 \mathrm{~m} . \mathrm{y}$. based on "Sr isotopes." According to ages listed in a figure published by Gohn et al. (2008), virtually all of the CBIS in-crater deposits (aka "Calvert II" in Fig. 14) are of Miocene age.

Although ${ }^{87} \mathrm{Sr}^{86} \mathrm{Sr}$ dating can be highly precise (McArthur et al., 2001), the method 20 is not necessarily accurate. It has been the most successful in the study of tests of specific marine fauna recovered from deep-sea cores (e.g. Faure, 1986). The mechanism relates to potassium, and hence ${ }^{87} \mathrm{Rb}$, added to the oceans by weathering of granitic minerals on the continents. ${ }^{87} \mathrm{Rb} \beta$ decays to form additional ${ }^{87} \mathrm{Sr}$. Increased rates of continental weathering tend to raise the ${ }^{87} \mathrm{Sr}{ }^{86} \mathrm{Sr}$ ratio in the open ocean toward 0.711 , whereas the mid-ocean hydrothermal input ratio is closer to 0.703 (Beets, 1991).

An obvious corollary is that ${ }^{87} \mathrm{Sr}-{ }^{86} \mathrm{Sr}$ ratios determined for sedimentary deposits on a continental shelf are at risk of being invested with additional continental ${ }^{87} \mathrm{Sr}$ that has not been diluted to the full extent that it would have been had it reached the open
SED

4, 363-428, 2012

In plain sight: the Chesapeake Bay crater ejecta blanket

D. L. Griscom

Title Page

Abstract Introduction

Conclusions References

Tables

Figures

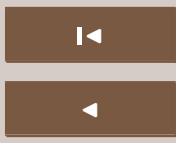

DI

Back

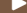

Close

Full Screen / Esc

Printer-friendly Version

Interactive Discussion 
ocean. Such an excess, if not carefully isolated, statistically quantified, and subtracted from the raw data could easily result in age determinations appearing to be younger than the actual ages, given that the open-ocean ${ }^{87} \mathrm{Sr}-{ }^{86} \mathrm{Sr}$ ratios have been monotonically increasing for the past 40 m.y. (e.g. McArthur et al., 2001). Apropos, Powars 5 (2000) reports that "An increase in concentrations of total dissolved-solids in the middle Potomac, Brightseat-upper Potomac, and Chickahominy-Piney Point aquifers coincides with the outer rim of the (CBIS) crater." Nevertheless, Gohn et al. (2008) display "agedepth plots primarily using Sr isotopes" for in-crater CBIS sediments without discussing their methods, providing references, or pointing to supplementary materials where the 10 details of their measurements are made available. Therefore, the Miocene ages they have assigned to the sediments interior to the CBIS remain unsupported by reliable data.

\section{A Northern Virginia diamicton yields remarkable clasts}

\subsection{The geologic setting}

15 According to a 1960s-vintage U.S. Geological Survey map, a dissected clay plateau $\sim 60-65 \mathrm{~m}$ above sea level stretching from Springfield, Virginia, (just south of the Washington Capital Beltway at its southerly junction with Interstate 95) to the author's former home $(\sim 10 \mathrm{~km}$ to the east-southeast) used to be everywhere dotted with gravel pits. About $0.6 \mathrm{~km}$ from his subdivision of Hollin Hills is the headwater of the Paul Spring Branch (PSB) of Little Hunting Creek, which empties into the Potomac River at Mount Vernon. Within Hollin Hills the PSB flows in a $\sim 3 \mathrm{~m}$-wide quartzite-cobble-lined channel in a $33 \mathrm{~m}$-deep valley with a gradient of $\sim 1 \mathrm{~m} \mathrm{~km}^{-1}$. Brickelmaier Park, set aside as a nature trail to preserve one of the natural drainage channels, slopes downward at $\sim 66 \mathrm{~m} \mathrm{~km}^{-1}$ toward PSB (and away from the CBIS). One result of this terrific gradient has been the incision of a gorge $\sim 3 \mathrm{~m}$ deep in the soft clays part way downslope. Yet this occasionally vigorous rivulet levels out near a point $\left(38^{\circ} 45^{\prime} 37.2^{\prime \prime} \mathrm{N}, 77^{\circ} 3^{\prime} 56.2^{\prime \prime} \mathrm{W}\right)$

\section{SED}

4, 363-428, 2012

\section{In plain sight: the Chesapeake Bay crater ejecta blanket}

D. L. Griscom

Title Page

Abstract

Introduction

Conclusions

References

Tables

Figures

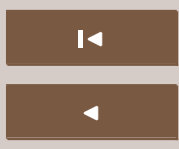

- I

Back

Close 
where the author noticed that it had managed to cut only $\sim 30 \mathrm{~cm}$ into a resistant layer, superficially appearing to be a massive whitish-gray clay (Fig. 16a).

Upon being shown this outcrop, impact geologist Kevin Pope declared it to be a debris flow. Hence, this unit is here dubbed the "Hollin Hills Diamicton" (HHD). Mi-

5 croscopic examinations and XRD revealed the whitish-gray "clay" matrix to comprise nearly $100 \%$ quartz silt. Griscom et al. (2003) published a photomicrograph of a quartz grain collected from this stratum displaying 3 intersecting sets of planar deformation features - normally a signature of shock overpressures typical of major impacts on the earth. However, to be an indisputable indicator of shock overpressures requires exam10 ination of individual grains on a microscope with a U-stage (e.g., Koeberl et al., 1996; French, 1998), whereas such studies have not yet been performed.

During aperiodic visits to this site, the author noticed that the rivulet had exhumed, or was in the process of exhuming, several very unusual clasts from the HHD. Figure 16 displays a subset of these finds, down-selected to those with stories that can be related 15 in useful detail.

\subsection{Unusual rocks, almost certainly crater ejecta}

\subsubsection{The autobrecciated chalk ball}

This object is shown in the upper part of Fig. $16 \mathrm{~b}$ as it was dug out after being discovered partially exhumed in the segment of the HHD traversed by the rivulet. The 20 friable orange-brown crust on its bottom (spontaneously crumbling after desiccation) likely covered its top surface as well but was stripped away by the stream. On viewing the sawed slab, Kevin Pope described this object as "autobrecciated." Inspected with a hand lens, the matrix appears fossil-free, whereas a few of the clasts display one or two split ovoid objects $\sim 1 \mathrm{~mm}$, which could be benthic forams.

25 This fragile specimen certainly could not have been emplaced by a river because it would not have survived fluvial transport as far as $10 \mathrm{~m}$ and there is no record - or expectation - of any chalk outcrops anywhere above sea level in Virginia. However,

SED

4, 363-428, 2012

In plain sight: the Chesapeake Bay crater ejecta blanket

D. L. Griscom

Title Page

Abstract

Introduction

Conclusions

References

Tables

Figures

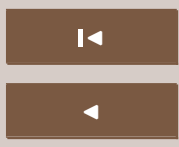

Back

Full Screen / Esc

Printer-friendly Version

Interactive Discussion
$>1$

Close (a)

列

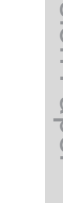


the eustatic sea level was as high as $300 \mathrm{~m}$ above present during much of the Cretaceous and it remaining as high as $150 \mathrm{~m}$ throughout most of the Paleocene and Eocene Epochs (Fig. 6). Therefore, some pelagic limestones were almost certainly present in the target area of the CBIS impactor ...leaving the clast of Fig. 16b no other explanation 5 than as being a Chesapeake Bay crater impactite. In the event that further proof should be desired, it should be possible to date this specimen on the basis of its $\mathrm{Ca} / \mathrm{Mg}$ ratio (Stanley, 2006). (The author would be pleased to make available research samples of any of the clasts reported here.)

\subsubsection{A pseudo-palagonite "cinder"}

10 The $8.5 \mathrm{~cm}$-tall object illustrated in Fig. 16c matches the Glossary of Geology (Neuendorf et al., Eds., 2005) definition of palagonite. However, it is highly unlikely to be of volcanic origin given its siliciclastic nature. The only crystalline minerals identified by XRD of a powdered sample of the orange-brown material selected to be as free as possible of quartz inclusions were goethite and quartz. Both sets of diffraction lines were relatively weak, suggesting there may be a glassy component. This object's grooved and pitted surface was densely packed with the whitish-gray quartz silt in which it was found embedded. Moreover, a slab sawed from the bottom of the object (bottom of Fig. 16c) reveals what appears to be $\sim 3 \mathrm{~mm}$ clods of the same quartz silt encased in its interior. Therefore, this clast is interpreted as a blob of glassy silica launched during the jetting-stage (cf. Sect. 5.2.2) of the CBIS impact, which while still molten accreted slower moving quartz fragments and silt while in hypervelocity ballistic flight.

\subsubsection{A melt-encrusted clay fragment}

The object of Fig. 16d, aside from its rind, appears to fit Poag's (1997) description of certain clasts incorporated into the Exmore breccia that are "not known elsewhere sive, greenish gray clay seen in all four core holes." Petrologist Bevin French (private

SED

4, 363-428, 2012

In plain sight: the Chesapeake Bay crater ejecta blanket

D. L. Griscom

Title Page

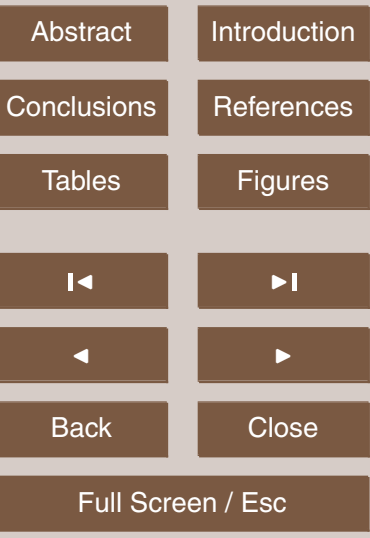

Printer-friendly Version

Interactive Discussion 
communication) described the present object this way: "Interior material is massive, soft, shows shrinkage cracks. Resembles clay; easily scratched or gouged with metal point or fingernail." The unique five-layer rind (mottled brownish orange viewed from the outside, black, cream, greenish cream, and a perturbed zone of the pail greenish 5 gray interior) is tentatively interpreted as a diagenetically altered glass/ceramic multilayer created by a very brief external temperature rise of "tens of thousands of degrees" (Melosh, 1989) associated the jetting stage of the CBIS impact.

\subsubsection{A doubly-fractured quartzite cobble emplaced in one piece}

The three objects of Fig. 16e were found partially exposed in the HHD tightly meshed

together. So without a doubt, this quartzite cobble was subjected to one complete and two partial co-parallel planar fractures before deposition. Its final splitting must have been due to freeze-thaw cycles, since nothing else could have affected it while entombed in the massive quartz-silt sarcophagus in which it was found. This finding reinforces the conclusion of Sect. 4.3 that the fracturing of the rocks of Fig. 7 was due to impact-produced tensile waves associated with the interference zone of the CBIS impact.

\subsection{The significance of the Hollin Hills diamicton}

In principle, the HHD is a jetting-stage deposit, in which case it should stratigraphically lie between the pre-impact surface and the overlying interference-zone ejecta (deduced in Sect. 4.1 to be synonymous with the gravel component of the upland deposits). However, the stratigraphic relationship of the HHD to the upland deposits is ambiguous due to its only outcrop being out of contact with, and topographically lower than, the latter.

Given the properties of the jetting stage mentioned in Sect. 5.2.2, the pre-impact landforms facing the crater would surely have been attacked by an abrasive sheet of hypervelocity impactor and target debris entrained in the jet, possibly accounting for the scarp-free, concave-upward crater-facing surface of offlaping clay-terraces forming

In plain sight: the Chesapeake Bay crater ejecta blanket

D. L. Griscom

\section{Title Page}

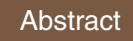

Introduction

Conclusions

References

Tables

Figures

14

$>$ I

4

Back

Close 
the base of the upland deposits of Southern Maryland (Fig. 9) ...and perhaps also the concave-upward, crater-facing Petersburg-granite outcrop forming the sub-base of the upland deposits in Midlothian, Virginia, (Fig. 13a). (The HHD faces away from the crater.)

5 Goodwin and Johnson (1970) called particular attention to the fact that at Midlothian "....a discontinuous basal cobble zone and overlying thick clay underlie the gravel member of the upland deposits." Therefore, this $\sim 1.4$ m deep basal unit, so beautifully illustrated in Fig. 13a, is an unambiguous candidate for a jetting-stage deposit (being the only ejected materials that could possibly have arrived before the interference-zone10 ejecta-cum-upland deposits). There are a number of ways to verify this possibility, beginning with checking the "ferricrete" layer (cf. Sect. 2.3.2) for continuity. If it is continuous except for in situ cracks and/or damage traceable to the excavation of the road cut, this would mean that the ferrihydrite binder arrived in molten form, rather than solid Grady-Kipp fragments (cf. Sect. 4.1). Also, the curved surface of the Petersburg granite 15 substrate should be checked for striations and/or other types of scars attributable its having been sculpted by withering barrage of hypervelocity rock fragments associated with the contact-and-compression stage (Melosh, 1989) of the CBIS impact.

Finally, if the "overlying thick clay" member of Goodwin and Johnson's (1970) basal bilayer illustrated in Fig. 13a should be found to correlate with the "whitish-gray clay" (actually determined to be nearly pure quartz silt) of the HHD, it might then be possible to find a way to utilize subtle differences between these two deposits (angularly separated by $50^{\circ}$ with respect to the crater center) to estimate the degree of anisotropy in the CBIS jetting phase .... with the object of determining the direction of approach and the angle of impact of the CBIS impactor - which usually cannot be learned from the shape of the final crater (Melosh, 1989).

In addition, this unit should be searched exhaustively for fragments of the impactor itself, which are bound to be found in jetting-phase deposits (Melosh, 1989) ...even though the author failed to find anything that he thought might qualify as such in the HHD.

\section{SED}

4, 363-428, 2012

\section{In plain sight: the Chesapeake Bay crater ejecta blanket}

D. L. Griscom

Title Page

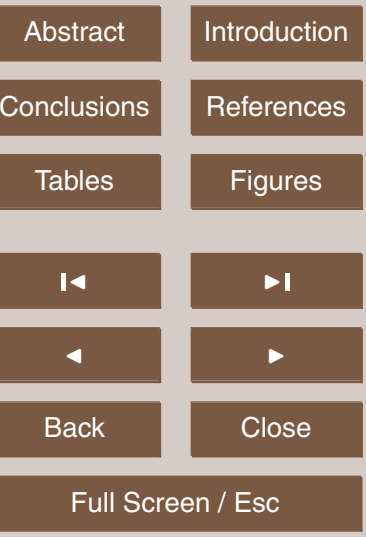

Printer-friendly Version

Interactive Discussion 


\section{A spall of Langley Granite in plain sight?}

The author's former home in Hollin Hills, Virginia, was 20 years old when purchased and came with a half-buried boulder at the top of the driveway ...possibly dug up by a workman who considered it far too interesting to re-inter beneath the concrete slab of 5 the carport. It was about 20 years later when the author finally dug it out and viewed it from other angles. Most striking were the streaks extending up the sides from vaguelydome-shaped "anterior" surface to a relatively flat "posterior" side ...which was encircled by a raised lip (Fig. 17a and e)! To one familiar with button tektites (e.g. Glass, 1990 ), it was instantly obvious that this rock must be a meteorite. But it was clearly 10 granite and thus a candidate for a meteorite from a Terrestrial Planet (Gladman et al., 1996) ...very likely our own.

This quasi-pentagonal-prismatic object (cf. Fig. 17e) possesses an average 2:1 diameter-to-height ratio. Its anterior (domed) surface differs from its streaked sides by being smoother, free of streaks or any other patterns, and showing a faint orange 15 coloration (Fig. 17b and f). In contrast, its posterior surface (Fig. 17e) has the same coloration as the sides but displays a mottled pattern of dark gray-brown splotches rather than streaks. The average size and quasi-periodicity of these splotches were found to be correlative with those of biotite crystals in the interior of the object, as determined by chipping off a 3-by- $6 \mathrm{~cm}$ fragment from the edge of the posterior surface.

An unsuccessful attempt was made to reproduce the streaks on the sides by means of a well-tuned $\mathrm{H}_{2}-\mathrm{O}_{2}$ torch $\left(\sim 2800^{\circ} \mathrm{C}\right)$ applied tangentially to a freshly fractured sample of pink biotite granite; (N. B. the temperature of the Apollo command-module heat shields rose to $2800^{\circ} \mathrm{C}$ on reentry (Allday, 2000).) However this experiment was instructive: Low-viscosity molten biotite actually erupted from the interiors of viscous blobs of molten silicate glass and spread out in thin jet-black surface layers. Similar jet-black patches (presumed to be frozen puddles of melted biotite) were detected mainly on a single vertical face of the present object (Fig. 17b and c). Notably, the sole jet-black patch on the posterior face is seen in Fig. 17e to be located very near its geometric center.

\section{SED}

4, 363-428, 2012

\section{In plain sight: the Chesapeake Bay crater ejecta blanket}

D. L. Griscom

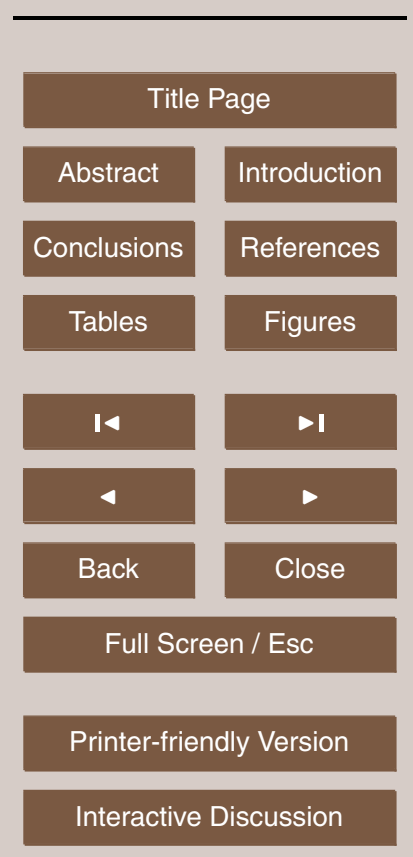

Interactive Discussion 
It is inferred that this piece of granite must have assumed a quasi-stable attitude upon reentering the Earth's atmosphere ....and that the right-hand face of Fig. 17b (enlarged in Fig. 17c) was the only one of the five nearly-vertical surfaces where the hypersonic air flow tended to separate, thus protecting the low-viscosity puddles of 5 molten biotite from being blown away. The near-central jet-black dot on the posterior surface (Fig. 17e) may have a related story.

N. B. These amorphous biotite "puddles" should be excellent candidates for Ar-Ar dating of this object. Moreover, it would be of considerable general interest to determine if the mineralogy of this bolide might be correlative with the basement granite 10 intercepted by the USGS-NASA Langley Corehole at Hampton, Virginia (Horton et al., 2005). If so, then Horton et al.'s (2005) suggestion that the chlorite component of the Langley Granite may be due to "pseudomorphous replacement of biotite" would have to be true. Indeed, the fractured basement granite was surely in contact with sea water for most of the past 35.4 m.y. whereas the rock of Fig. 17, found at $65 \mathrm{~m}$ above present 15 sea level, would have been touched by sea water only during the late Eocene and perhaps briefly during the middle Miocene (cf. Fig. 6).

\section{Summary}

This paper has endeavored to take into account every geomorphological, geophysical, impact-geological, petrological, paleontological, and paleoclimatological issue that in any way impinges on the question of which, if any, of the present-day surface features of the U.S. Middle-Atlantic Coastal Plain are likely to be surviving vestiges of the original Chesapeake Bay crater ejecta blanket. With regard to this objective, the author has here identified (a) two mapped formations (the Bacons Castle and the Shirley), (b) one extensively mapped informal unit (the upland deposits), and (c) a pair of un25 mapped diamictons (Figs. 13a and 16) as respectively matching ( $\mathrm{a}^{\prime}$ ) excavation-stage and curtain ejecta, $\left(b^{\prime}\right)$ interference-zone ejecta overlain by base-surge ejecta, and $\left(c^{\prime}\right)$ jetting-stage ejecta. These identifications follow from the close matches of the
SED

4, 363-428, 2012

\section{In plain sight: the Chesapeake Bay crater ejecta blanket}

D. L. Griscom

Title Page

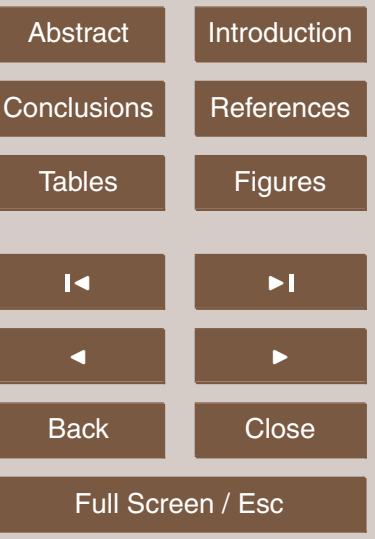

Printer-friendly Version

Interactive Discussion 
properties of the three geological units listed above to the respective characteristics of the five evoked stages of impact cratering as laid out in mathematical detail by Melosh (1989), reinforced by the facts that the author has (1) here demonstrated the canonical explanation of the upland deposits as being of fluvial origin to be palpably improbable 5 by some measures and physically impossible by others and (2) previously proven that the hard ferrihydrite sheets that characteristically bond together some of the gravels of the upland deposits are impactoclastic in origin (Griscom et al., 2003). In addition, it is pointed out here that for as long as the ejecta blanket of the CBIS was (and arguably still is) in existence, infilling of the crater would (will) be solely due to inward mass 10 wasting of this ejecta blanket. As a corollary, the canonical assumption that there is an in-crater physical hiatus of duration $\sim 13$ to-19 m.y. - beginning when the crater had scarcely begun to fill - is physically impossible.

In effect, the canonically accepted stratigraphic column of the U.S. Middle-Atlantic Coastal Plain appears to have been misinterpreted and misdated long ago by highly competent geologists disadvantaged by living in a time when impact cratering as a geologic process (Melosh, 1989) was but a zephyr in "the wind of the oncoming future" (Eiseley, 1973). Indeed, those fine geologists had no choice but to interpret a set of truly bizarre landforms (mis)guided by the precept of uniformitarian geology stating:

"The geological forces of the past differ neither in kind nor in energy from those now 20 in operation." (Neuendorf et al., Eds., 2005).

Thanks to the incredibly good fortune of never having been saddled with this disadvantage, the present author humbly concludes on the basis of what he believes to be more than adequate evidence and argument that approximately $10000 \mathrm{~km}^{2}$ of the U.S. Middle-Atlantic Coastal Plain and Piedmont Province still display vestiges (commonly $\geq 10 \mathrm{~m}$ deep) of the Chesapeake Bay crater ejecta blanket..."in plain sight."

Acknowledgements. The author owes a debt of gratitude to Kevin Pope (Geo Eco Arc Research) for his first-hand assessment of the Hollin Hills Diamicton, for storing the author's rock collection for several years while he was living abroad, and for making freely available his microscopes and rock saw. Celia Merzbacher (then Naval Research Laboratory) is thanked for
SED

4, 363-428, 2012

\section{In plain sight: the Chesapeake Bay crater ejecta blanket}

D. L. Griscom

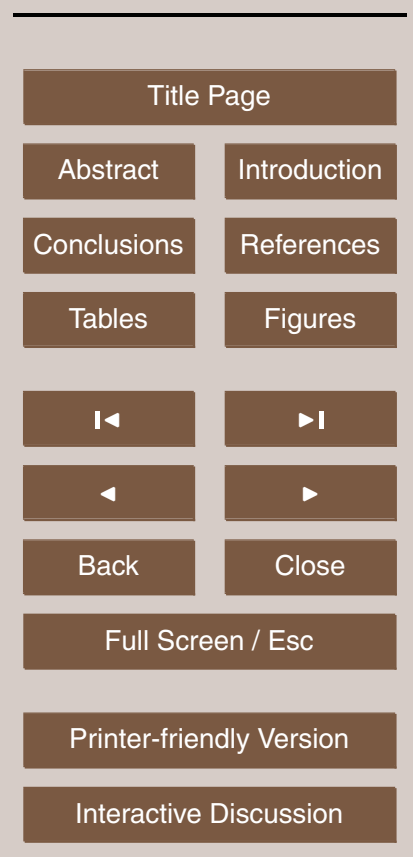


kindly recording a number of XRD patterns after hours. Thanks are also due Bevin French (Smithsonian Institution) for carefully studying a number of rock samples collected by the author and reporting his expert assessments of their petrologic natures. The researching and writing of this manuscript and the preparation of all figures were carried out by the author with5 out external financial support.

\section{References}

Allday, J.: Apollo in Perspective: Spaceflight Then and Now, CRC Press, 2000.

Baker, V. R.: The study of super floods, Science, 295, 2379-2380, doi:10.1126/science.1068448, 2002.

10 Beets, C. J.: The late Neogene ${ }^{87} \mathrm{Sr}^{86} \mathrm{Sr}$ isotopic record in the western Arabian Sea, site 722, in Proc. Ocean Drilling Prog., Scientific Results 117, 459-463, doi:10.2973/odp.proc.sr.117.166.1991, 1991.

Boslough, M. B.: Shock modification and chemistry and planetary geologic processes, Annu. Rev. Earth Planet. Sci., 19, 101-130, 1991.

Bottomley, R., Grieve, R. A. F., York, D., and Masaitis, V.: The age of the Popigai impact event and its relationship to events at the Eocene/Oligocene boundary, Nature, 288, 365-368, 1997.

Bradt, R. C. and Tressler, R. E.: Fractography of Glass, Springer, New York, 1994.

Carter, R. M.: Two models: global sea-level change and sequence stratigraphic architecture, Sedimentary Geology, 122, 23-36, doi:10.1016/S0037-0738(98)00111-0, 1998.

Chesterman, C. W. and Loew, K. E.: The Audubon Society Field Guide to North American Rocks and Minerals, Alfred A. Knopf, Tokyo, 1978.

Crawford, D. A.: A computational model of the Chesapeake Bay impact, presented at the 2002 Geological Society of America Annual Meeting, Denver, Colorado, 2002.

Dragon Run Steering Committee: The state of Dragon Run, Status of natural resources, Virginia Department of Conservation and Recreation Report, 2003.

Eiseley, L.: The Man Who Saw Through Time. Charles Scribner's Sons, New York, 1973.

Faucett, P. J. and Boslough, M. B. E.: Climatic effects of an impact-induced equatorial debris ring, J. Geophys. Res., 107, 4231-4249, doi:10.1029/2001JD001230, 2002.

30 Faure, G.: The Rb-Sr method of dating, in Principles of Isotope Geology, 2nd Edn., John Wiley and Sons, New York, 1986.

\section{SED}

4, 363-428, 2012

\section{In plain sight: the \\ Chesapeake Bay \\ crater ejecta blanket}

D. L. Griscom

Title Page

Abstract

Introduction

Conclusions

References

Tables

Figures

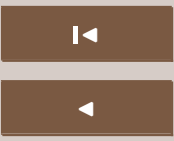

$\Delta$

Back

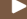

Close

Full Screen / Esc

Printer-friendly Version

Interactive Discussion 
French, B. M.: Traces of Catastrophe - A Handbook of Shock Metamorphism Effects in Terrestrial Meteorite Impact Structures, LPSI Contribution No. 954, Lunar and Planetary Institute, Houston, 1998.

Frye, K.: Roadside Geology of Virginia, Mountain Press, Missoula, Montana, 1986.

5 Gladman, B. J., Burns, J. A., Duncan, M., Lee, P., and Levison, H. F.: The exchange of impact ejecta between terrestrial planets, Science, 271, 1387-1392, doi:10.1126/science.271.5254.1387, 1996.

Glass, B. P.: Tektites and microtektites: key facts and inferences, Tectonophysics, 171, 393404, doi:10.1016/0040-1951(90)90112-L, 1990.

10 Gohn, G. S., Koeberl, C., Miller, K. G., Riemold, W. U., Browning, J. V., Cockell, C. S., Horton Jr, J. W., Kenkman, T., Kulpecz, A. A., Powars, D. S., Sanford, W. E., and Voytek, M. A.: Deep drilling into the Chesapeake Bay impact structure, Science, 320, 1740-1745, doi:10.1126/science.1158708, 2008.

Goodwin, B. K. and Johnson, G. H.: Guidebook, $11^{\text {th }}$ Annual Field Conference of the Atlantic 15 Coastal Plain Geological Association, http://abob.libs.uga.edu/bobk/cbayvirg.html, 1970.

Griscom, D. L.: Possible identification of proximal ejecta from the Upper-Eocene Chesapeake Bay crater, ESF-IMPACT Workshop, $6^{\text {th }}$, Granada, Spain, Abstracts, 35, 2001.

Griscom, D. L.: Is Washington DC built on ejecta deposits of the upper-Eocene Chesapeake Bay Crater?, ESF-IMPACT Workshop, $9^{\text {th }}$, Prague, Czechoslovakia, Abstracts, 23, 2002.

20 Griscom, D. L.: Chesapeake Bay crater ejecta are alive and well and living in Maryland. Virginia, and the District of Columbia ...disguised as $\sim 5000 \mathrm{~km}^{2}$ of "upland deposits", Geological Society of America Wetumpka Field Forum 2007 Guidebook and Abstracts, 85, 2007a.

Griscom, D. L.: $\sim 200 \mathrm{~km}^{3}$ of Eocene sediments preserved on the U.S. Mid-Atlantic Coastal Plain by the armoring effect of overlying Chesapeake-Bay-crater ejecta, Geological Society of America Penrose Conference "The Late Eocene Earth" Abstracts, 29, 2007b.

Griscom, D. L. and Bolden, E. A.: Possible Chesapeake-Bay-Crater ejecta found at 4.5 crater radii, Eos Transactions, American Geophysical Union 80, S211, 1999.

Griscom, D. L., Akiyoshi, A., Homae, T., Kondo, K., Yamanaka, C., Ueno, T., Ikeya, M., Affatigato, M., and Schue, A.: Fossil natural glasses composed of ferric oxyhydroxides: Impactites of the 35.5 million year old Chesapeake Bay crater, J. Non-Cryst. Solids, 323, 7-26, doi:10.1016/S0022-3093(03)00304-1, 2003.

Hack, J. C.: Geology of the Brandywine area and origin of the upland of southern Maryland, U.S. Geological Survey Professional Paper 267A, 41, 1955.
SED

4, 363-428, 2012

\section{In plain sight: the Chesapeake Bay crater ejecta blanket}

D. L. Griscom

Title Page

Abstract

Introduction

Conclusions

References

Tables

Figures

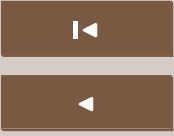

$>$

Back

Close

Full Screen / Esc

Printer-friendly Version

Interactive Discussion 
Hallam, A.: Pre-Quaternary sea-level changes, Ann. Rev. Earth Planet. Sci., 12, 205-243, 1984.

Haq, B. U., Hardenbol, J., and Vail, P. R.: Chronology of fluctuating sea levels since the Triassic, Science, 235, 1156-1167, doi:10.1126/science.235.4793.1156, 1987.

5 Hobbs, C. H.: York River geology, J. Coastal Research, SI (57), 10-16, doi:10.2112/1551-503657.sp1.10, 2009.

Horton Jr, J. W., Aleinikoff, J. N., Kunk, M. J., Naeser, C. W., and Naeser, N. D.: Petrography, structure, age, and thermal history of granitic Coastal Plain basement in the: Chesapeake Bay Impact Structure, USGS-NASA Langley core, Hampton, Virginia, in Studies of the Chesapeake Bay Impact Structure - The USGS-NASA Langley Corehole, Hampton, Virginia, and related coreholes and geological surveys, edited by: Horton Jr, J. W., Powars, D. S., and Gohn, G. S., B1-B29, U.S. Geological Survey Professional Paper 1688, 2005.

Horton Jr, J. W., Gohn, G. S., Powars, D. S., and Edwards, L. E.: Origin and emplacement of impactites in the Chesapeake Bay impact structure, Virginia, USA, GSA Special Papers, 437, 73-97, doi:10.1130/2008.2437(06), 2007.

Jaeger, H. M. and Nagel, S. R.: Physics of the granular state, Science, 255, 1523-1531, doi:10.1126/science.255.5051.1523, 1992.

King Jr, D. T. and Petruny, L. W.: Stratigraphy and sedimentology of coarse impactoclastic units within the Cretaceous-Tertiary boundary section, Albion Island, Belize, in Impact Markers in the Stratigraphic Record, edited by: Koeberl, C. and Martínez-Ruiz, F., 207-227, (SpringerVerlag, Berlin, 2003.

King Jr, D. T., Demick, J. D., Pope, K. O., and Ocampo, A. C.: Surface markings on Chicxulub ejecta clasts from Belize, Central America (abstr.), Geological Society of America Abstracts with Programs 29(3), 12, 1997.

Koeberl, C., Poag, C. W., Reimold, W. U., and Brandt, D.: Impact origin of the Chesapeake Bay structure and source of the North American tektites, Science, 271, 1263-1266, doi:10.1126/science.271.5253.1263, 1996.

Krantz, D. E. and Powars, D. S.: Hydrogeologic setting and potential for denitrification in ground water, Coastal Plain of Southern Maryland, USGS Water-Resources Investigations Report 00-4051, U.S. Dept. Interior, U.S. Geological Survey, in cooperation with Maryland Dept. Environment and Maryland Dept. Natural Resources, 2000.

Lambeck, K. and Chappell, J.: Sea level change through the last global cycle, Science, 292, 679-686, doi:10.1126/science.1059549, 2001.

\section{In plain sight: the Chesapeake Bay crater ejecta blanket}

D. L. Griscom

Title Page

Abstract

Introduction

Conclusions

References

Tables

Figures

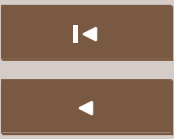

$\rightarrow 1$

Back

Close

Full Screen / Esc

Printer-friendly Version

Interactive Discussion 
Marcus, R., Melosh, H. J., and Collins, G.: Earth Impact Effects Program, Imperial College London/Purdue University, http://impact.ese.ic.ac.uk/ImpactEffects/, 2010.

Matthews, H. L., Hodges, R. L., and Amos, D. F.: Some geological and geomorphological observations of Chesterfield County (abstr.), Va. Acad. Sci. Proc., 16, 380-381, 1965.

5 McArthur, J. M., Howarth, R. J., and Bailey, T. R.: Strontium isotope stratigraphy: LOWESS Version 3: Best fit to the marine Sr-isotope curve for 0-509 Ma and accompanying look-up table for deriving numerical age, J. Geol., 109, 155-170, 2001.

McGetchin, T. R., Settle, M., and Head, J. W.: Radial thickness variation in impact crater ejecta: Implications for lunar basin deposits, Earth Planet. Sc. Lett., 20, 226-236, 1973.

10 Means, J.: Roadside Geology of Maryland, Delaware, and Washington, D.C., Mountain Press Publishing, Missoula, Montana, 2010.

Mecholsky, J., Rice, R. W., and Freiman, S. W.: Predictions of Fracture Energy and Flaw Size in Glasses from Mirror Size Measurements, J. Am. Ceram. Soc., 57, 440-444, 1974.

Melosh, H. J.: Impact Cratering - A Geological Process, Oxford Monogr. Geol. Geophys Ser., 15 vol. 11, Oxford University Press, New York, 1989.

Michel, F. M., Ehm, L., Antao, S. M., Lee, P. L., Chupas, P. J., Liu, G., Strongin, D. R., Schoonen, M. A. A., Phillips, B. L., and Parise, J. B.: The structure of ferrihydrite, a nanocrystalline material, Science, 316, 1726-1729, doi:10.1126/science.1142525, 2007.

Miller K. G., Kent, D. V., Brower, A. N., Bybell, L. M., Feigenson, M. D., Olson, R. K., and Poore, R. Z.: Eocene-Oligocene sea-level changes on the New Jersey coastal plain linked to the deep-sea record, Geol. Soc. Am. Bull., 102, 331-339, 1990.

Mixon, R. B.: Stratigraphic and geomorphic framework of uppermost cenozoic deposits in the southern Delmarva Peninsula, Virginia and Maryland, Professional Paper 1067-G, U.S. Geological Survey, Reston, Virginia, 1985.

Mixon, R. B., Berquist Jr, C. R., Newell, W. L., Johnson, G. H., Powars, D. S., Schindler, J. S., and Rader, E. K.: Geologic map and generalized cross sections of the Coastal Plain and adjacent parts of the Piedmont, Virginia, Miscellaneous Investigations Series Map I-2033, U.S. Geological Survey, Reston, Virginia, 1989.

Neuendorf, K. K. E., Mehl Jr, J. P., and Jackson, J. A.: Glossary of Geology, Fifth Edition, American Geological Institute, Alexandria, Virginia, 2005.

Oberbeck, V. R.: The role of ballistic erosion and sedimentation in lunar stratigraphy, Rev. Geophys. Space Ge., 13, 337-362, 1975.

Ocampo, A. C., Pope, K. O., and Fischer, A. G.: Ejecta deposits of the Chicxulub crater from

\section{In plain sight: the Chesapeake Bay crater ejecta blanket}

D. L. Griscom

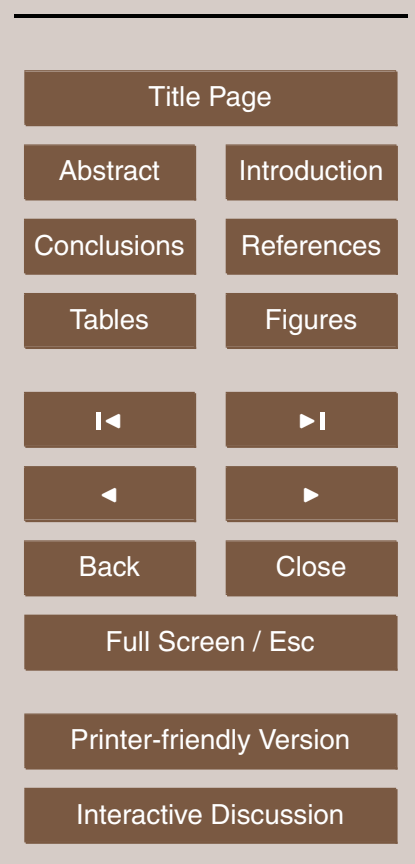

Interactive Discussion 
Albion Island, Belize, Geol. S. Am. S., 307, 75-88, 1996.

Pälike, H., Norris, R. D., Herrle, J. O., Wilson, P. A., Coxall, H. K., Lear, C. H., Shackelton, N. J., Tripati, A. K., and Wade, B. S.: The heartbeat of the Oligocene climate system, Science, 314, 1894-1898, doi:10.1126/science.1133822, 2006.

5 Peebles, P. C.: Late Cenozoic landforms, stratigraphy, and history of sea level oscillations of southwestern Virginia and northeastern North Carolina, Ph.D. Thesis, College of William and Mary, Williamsburg, Virginia, 1984.

Peebles, P. C., Johnson, G. H., and Berquist, C. R.: The middle and late Pleistocene stratigraphy of the outer Coastal Plain, southeastern Virginia, Virginia Minerals, 30, 2, 1984.

10 Pettijohn, F. J.: Sedimentary Rocks, Harper and Brothers, New York, 1949.

Poag, C. W.: The Chesapeake Bay bolide impact: a convulsive event in Atlantic Coastal Plain evolution, Sediment. Geol., 108, 45-90, doi:10.1016/S0037-0738(96)00048-6, 1997.

Poag, C. W. and Aubry, M.-P.: Upper Eocene impactites of the U.S. East Coast: Depositional origins, biostratigraphic framework, and correlation, PALAIOS 10, 16-43, 1995.

15 Poag, C. W. and Commeau, J. A.: Paleocene to middle Miocene planktonic foraminifera of the southwestern Salisbury Embayment, Virginia and Maryland: Biostratigraphy, allostratigraphy, and sequence stratigraphy, J. Foraminiferal Res., 25, 134-155, 1995.

Poag, C. W., Powars, D. S., Poppe, L. J., and Mixon, R. B.: Meteroid mayhem in Ole Virgini: Source of the North American tektite strewn field, Geology, 22, 691-694, 1994.

20 Poag, C. W., Koeberl, C., and Reimold, W. U.: The Chesapeake Bay Crater: Geology and Geophysics of a Late Eocene Submarine Impact Structure, Springer-Verlag, Berlin, 2004.

Pope, K. O., Ocampo, A. C., Fischer, A. G., Alvarez, W., Fouke, W., Webster, C. L., Vega, F. J., Smit, J., Fritsche, A. E., and Claeys, P.: Chicxulub impact ejecta from Albion Island, Belize, Earth Planet. Sc. Lett., 170, 351-364, 1999.

Powars, D. S., Poag, C. W., and Mixon, R. B.: The Chesapeake Bay "impact crater"; Stratigraphic and seismic evidence, Geol. Soc. Am. Abstr. Progr., 25, A-378, 1993.

Powers, D. S.: The Effects of the Chesapeake Bay Impact Crater on the Geologic Framework and the Correlation of Hydrogeologic Units of Southeastern Virginia, South of the James River, Professional Paper 1622, U.S. Geological Survey, Reston, Virginia, 2000.

30 Reed Jr, J. C., Sigafoos, R. S., and Fisher, G. W.: The river and the rocks, the geologic story of Great Falls and the Potomac River Gorge, U.S. Geological Survey Bull., 1471, 75, 1980.

Schlee, J.: Upland gravels of Southern Maryland, Geol. Soc. Am. Bull. 68, 1371-1410, 1957. Schultz. P. H. and Gault, D. E.: Atmospheric effects on martian ejecta emplacement, J. Geo-

\section{In plain sight: the Chesapeake Bay crater ejecta blanket}

D. L. Griscom

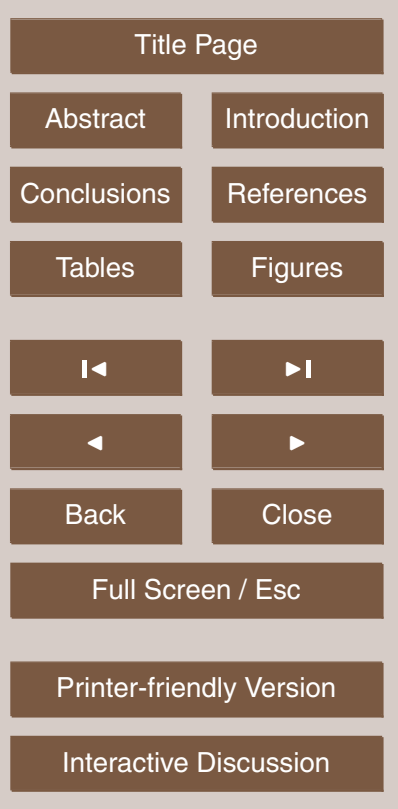

Interactive Discussion 
phys. Res., 84, 7669-7687, 1979.

Shanmugam, G. and Moiola, R. J.: Eustatic control of calciclastic turbidites, Marine Geology, 56, 273-278, 1984.

Shoemaker, E. M.: Interpretation of lunar craters, Physics and Astronomy of the Moon, edited by: Kopal, Z., Academic Press, New York and London, 283-259, 1962.

Stanley, S. M.: Influence of seawater chemistry on biomineralization throughout phanerozoic time: Paleontological and experimental evidence, Palaeogeogr. Palaeocl., 232, 214-236, doi:10.1016/j.palaeo.2005.12.010, 2006.

Steiner, M. B.: Implications of magneto-mineralogic characteristics of the Manson and Chicxulub impact rocks, in The Cretaceous-Tertiary Event and Other Catastrophes in Earth History, edited by: Ryder, G., Fastovsky, D., and Gartner, S., Geol. S. Am. S., 307, 89-104, 1996.

Vail, P. R. and Mitchum Jr, R. M.: Global cycles of relative changes of sea level from seismic stratigraphy, American Association of Petroleum Geologists Memoir, 29, 467-472, 1979.

Vail, P. R., Mitchum Jr, R. M., and Tompson III, S.: Seismic stratigraphy and global changes of sea level, Part 3, Relative changes of sea level from coastal onlap, in Payton, C.E., ed., Seismic Stratigraphy - Applications to Hydrocarbon Exploration, Am. Assoc. Pet. Geol. Mem., 26, 63-81, 1977.

Walker, J. C. G. and Kasting, J. F.: Effects of fuel and forest conservation on future levels of atmospheric carbon dioxide, Paleogeogr. Paleoclimatol. Paleoecon., 97, 151-189, 1992.

Warren, P. H., Claeys, P. H., and Cedillo-Pardo, E.: Mega-impact melt petrology (Chicxulub, Sudbury, and the Moon): Effects of scale and other factors on potential for fractional crystallization and development of cumulates, in The Cretaceous-Tertiary Event and Other Catastrophes in Earth History, edited by: Ryder, G., Fastovsky, D., and Gartner, S., Geol. Soc. Am. S., 307, 105-124, 1996.

Wentworth, C. K.: Striated cobbles in the southern States, Geol. Soc. Amer. Bull., 39, 941-953, 1928.

Wentworth, C. K.: Sand and gravel resources of the Coastal Plain of Virginia, Virginia Geological Survey Bulletin, 32, 146, 1930.

Zachos, J., Pagani, M., Sloan, L., Thomas, E., and Billups, K.: Trends, rhythms, and aberrations 30 on global climate $65 \mathrm{Ma}$ to present, Science, 292, 686-693, doi:10.1126/science.1059412, 2001.

\section{In plain sight: the Chesapeake Bay crater ejecta blanket}

D. L. Griscom

Title Page

Abstract

Introduction

Conclusions

References

Tables

Figures

14

$>1$

4

Back

$\triangleright$

Close

\section{Full Screen / Esc}

Printer-friendly Version

Interactive Discussion 


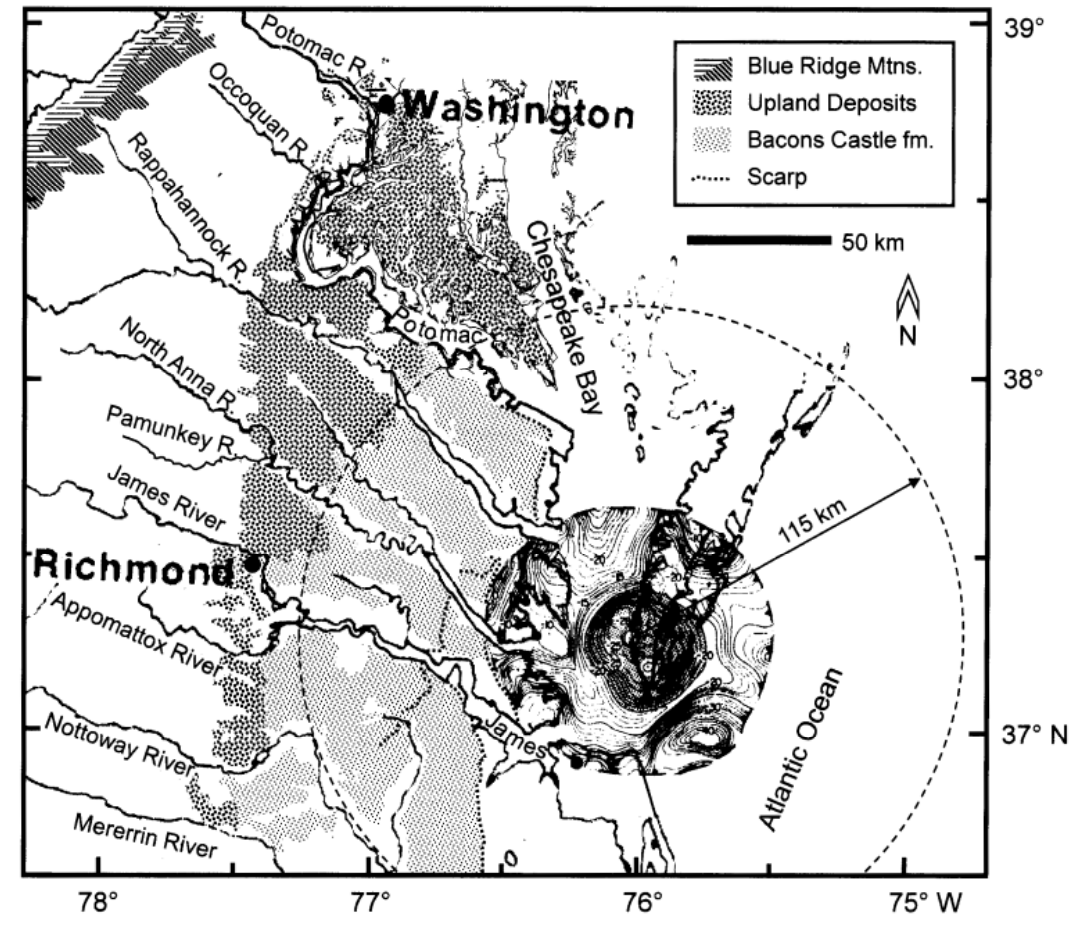

Fig. 1. Upland deposits of Southern Maryland, Eastern Virginia, and the District of Columbia (dark speckle pattern) and the Bacons Castle Formation of Eastern Virginia (lighter speckle pattern) are displayed in relation to the Chesapeake Bay Impact Structure, illustrated here by a cutout of the gravity map within the crater rim (adapted from C. Koeberl, C. W. Poag, W. U. Reimold, and D. Brandt, Science 271, 1263 (1996), reprinted with permission from AAAS). Mapped land surfaces are rough representations of more precise maps published by Schlee (1957), Krantz and Powars (2000), and Frye (1986). The dashed circle at a $115 \mathrm{~km}$ radius from the crater center at Cape Charles, Virginia, is provided for visual reference.
SED

4, 363-428, 2012

\section{In plain sight: the Chesapeake Bay crater ejecta blanket}

D. L. Griscom

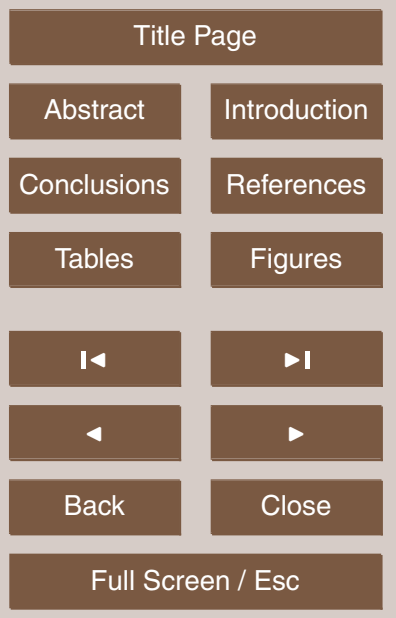

Printer-friendly Version

Interactive Discussion

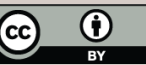




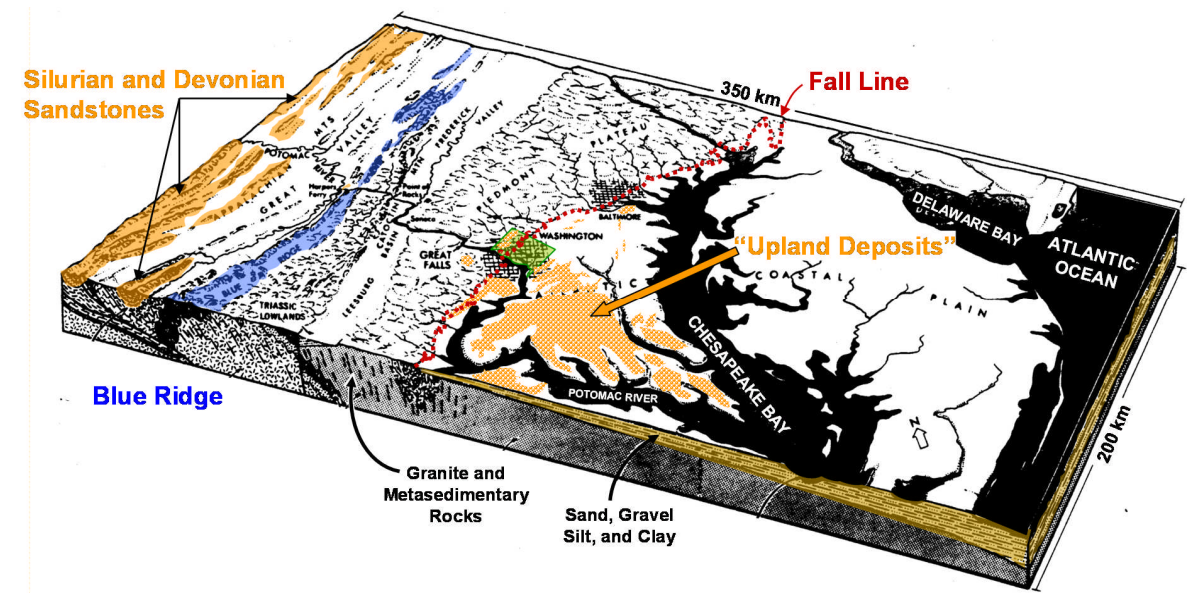

Fig. 2. Relief map of the Coastal Plain of Eastern and Southern Maryland and Delaware (southeastward of the Fall Line) and the Piedmont, Blue Ridge, and Valley and Ridge Provinces of Northern Virginia, Maryland, and West Virginia (successively northwestward of Fall Line) taken from the work of Reed et al. (1980) and used here in modified form courtesy of the U.S. Geological Survey. The orange-tinted patterns near to or southeast of the Fall Line roughly define a portion of the upland deposits only slightly larger than that studied by Schlee (1957).

\section{In plain sight: the Chesapeake Bay crater ejecta blanket}

D. L. Griscom

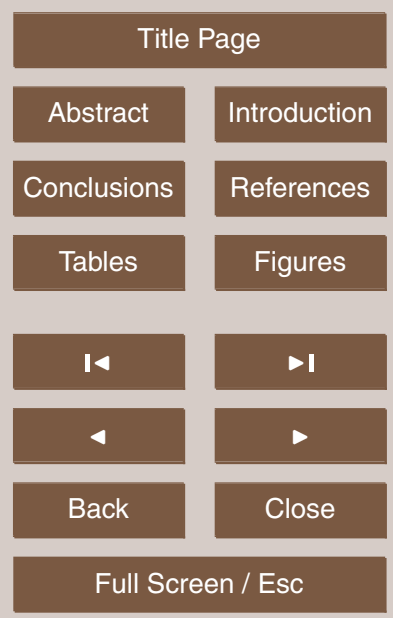

Printer-friendly Version

Interactive Discussion

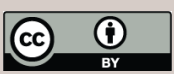




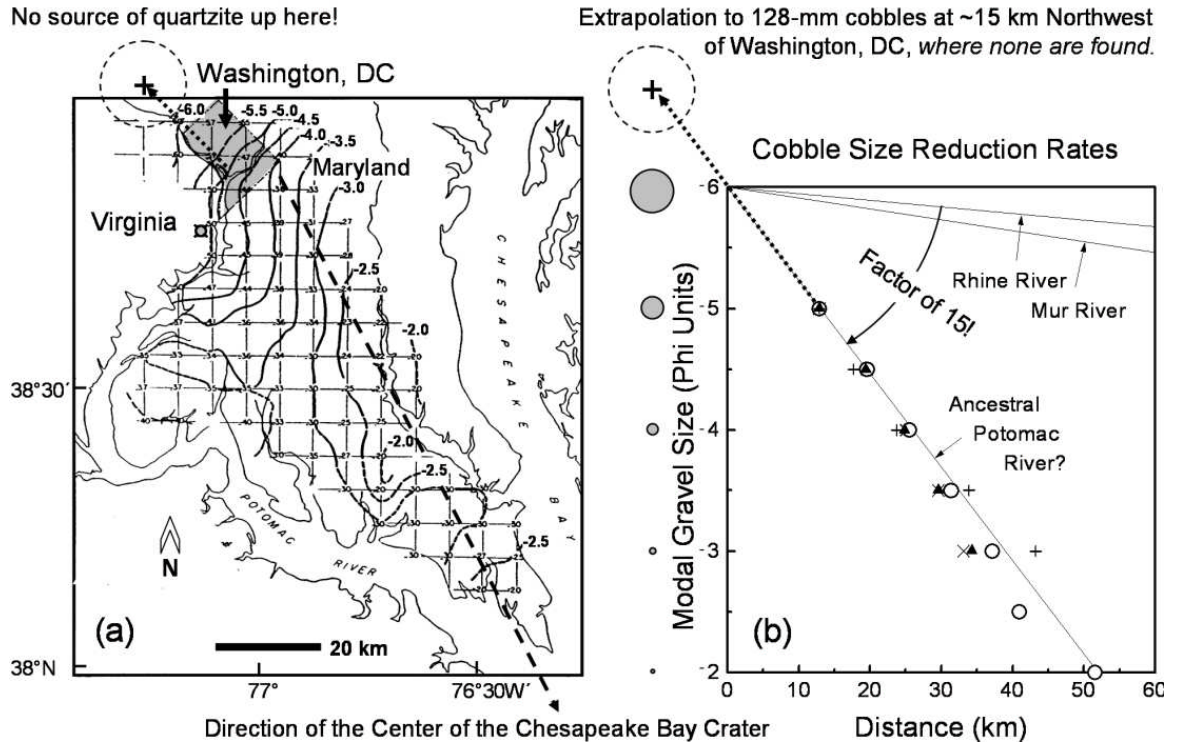

Fig. 3. (a) Moving-average modal-gravel-size isoliths for the mostly-quartzite gravel member of the upland deposits of the District of Columbia and Southern Maryland realized by Schlee (1957). (b) Schlee's (1957) modal gravel size data replotted versus distance for four separate paths chosen to be as nearly as possible perpendicular to the isoliths of (a), with comparisons to the cobble-size reduction rates for the modern Rhine and Mur Rivers. Boxed parts of (a) and (b) (both courtesy of the U.S. Geological Survey) are respectively reproduced and replotted from the originals; arrows, circles, and commentary external to the boxed materials were added by the present author.
SED

4, 363-428, 2012

\section{In plain sight: the Chesapeake Bay crater ejecta blanket}

D. L. Griscom

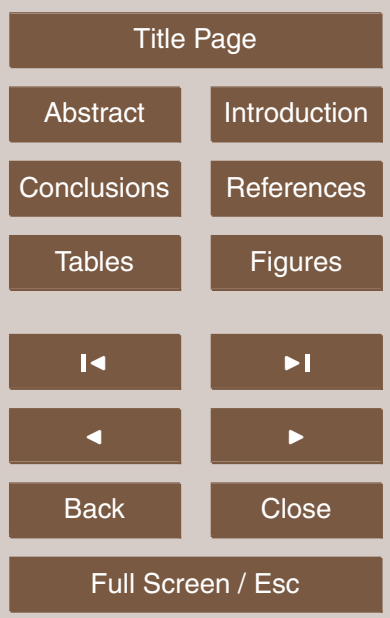

Printer-friendly Version

Interactive Discussion 


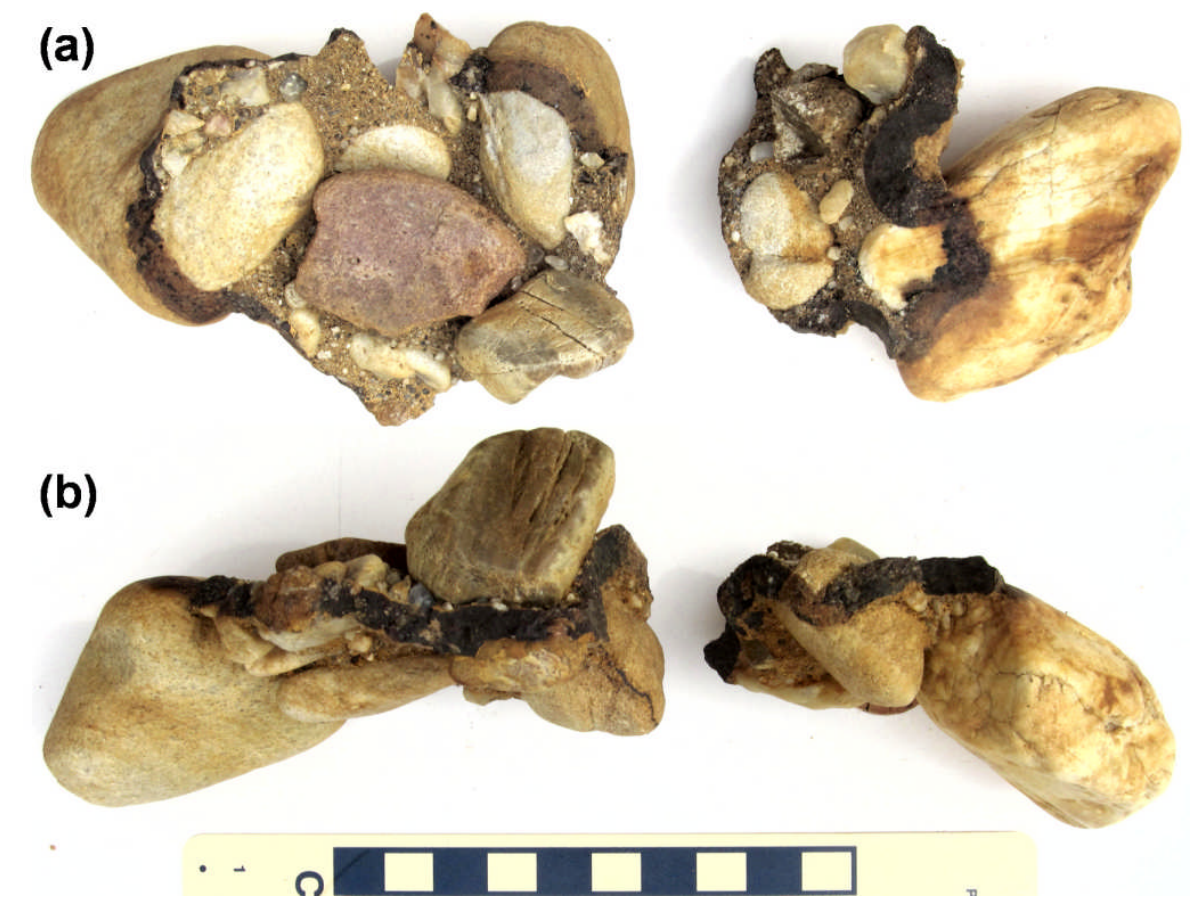

Fig. 4. Two clusters of webbed-together pebbles typical of the upland deposits. (a) Widest dimensions of "chocolate to ruddy brown" sheets are nearly parallel to the plane of the page. (b) Same objects each flipped $\sim 90^{\circ}$ along a horizontal axis. Note fresh conchoidal fractures of the $\sim 0.8 \mathrm{~cm}$-thick wavy sheets of ferrihydrite that firmly weld each cluster together. These specimens were trucked to the author's neighborhood as landfill from an excavation in Springfield, Virginia. Scale: centimeters.

\section{SED}

4, 363-428, 2012

\section{In plain sight: the Chesapeake Bay crater ejecta blanket}

D. L. Griscom

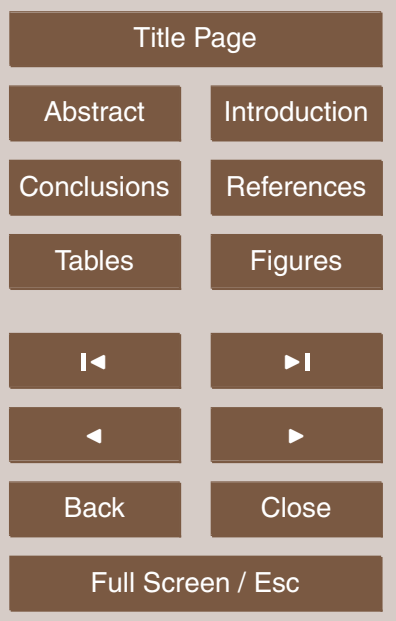

Printer-friendly Version

Interactive Discussion 


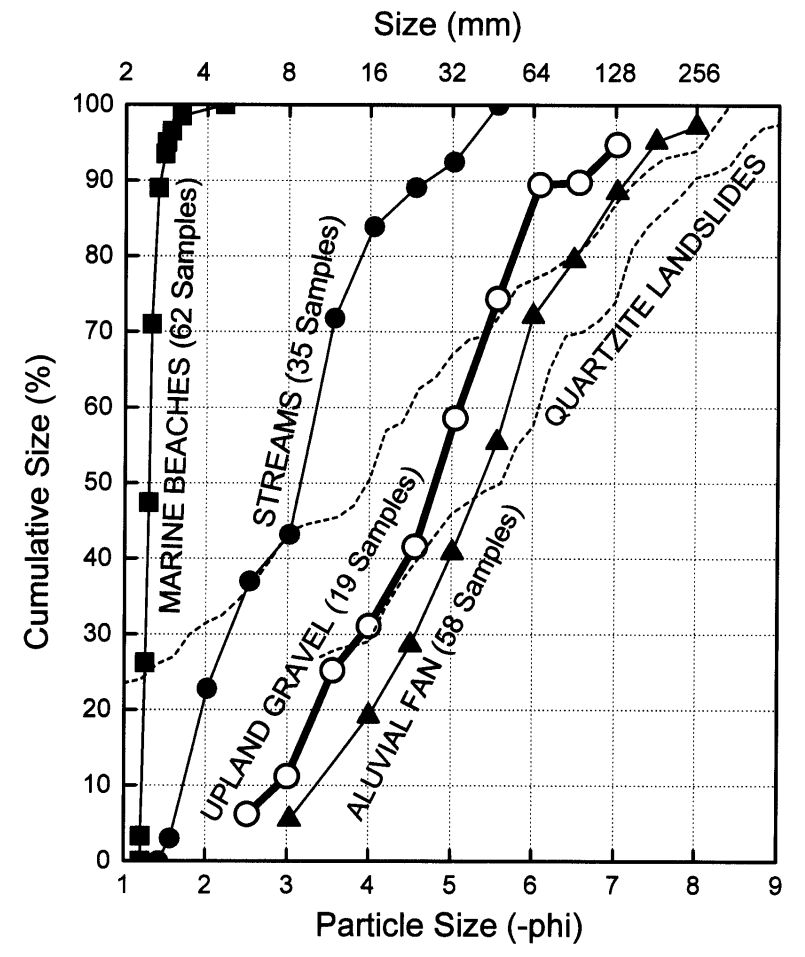

Fig. 5. Cumulative particle size distributions for various erosive environments. Solid black data points after Emery (1955); open circles due to Schlee (1957), whose figure is replotted here courtesy of the U.S. Geological Survey. In both of these cases the distributions were recorded as cumulative percentages of the total number of samples. Schlee's (1957) samples were pre-selected to have median sizes $\geq 10 \mathrm{~mm}$. By contrast, Attal and Lavé (2006) (dashed curves) sampled the results of landslides, sorted by lithology (quartzite shown), weighed particles coarser than $10 \mathrm{~mm}$ in the field, and determined the size distributions of the finer fraction in the laboratory.
SED

4, 363-428, 2012

\section{In plain sight: the Chesapeake Bay crater ejecta blanket}

D. L. Griscom

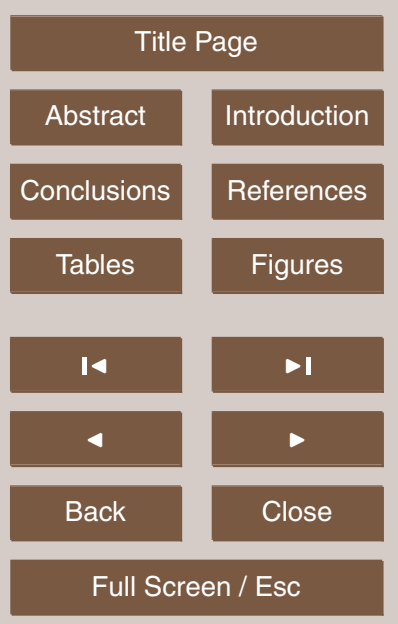

Printer-friendly Version

Interactive Discussion 


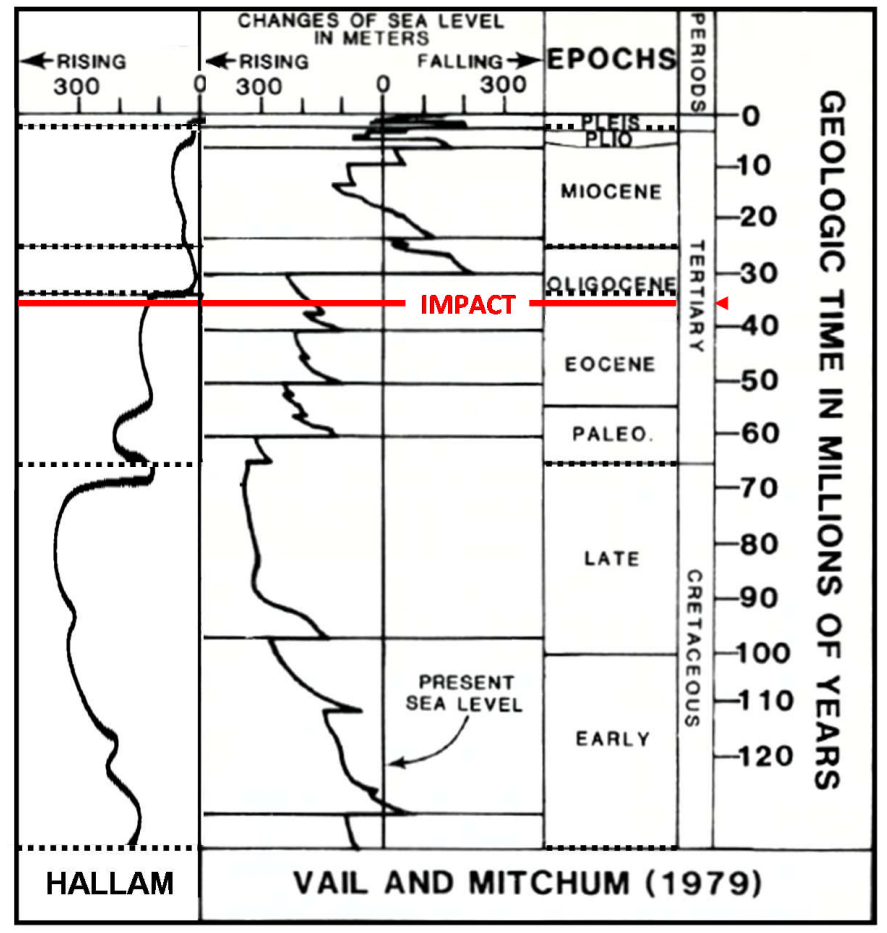

Fig. 6. Eustatic sea levels from $144 \mathrm{Ma}$ to the present according to Hallam (1984) and Vail and Mitchum (1979). (The actual figure for right hand columns is taken from Shanmugam and Moiola (1984) with the permission of Elsevier Ltd.) The left hand column was scanned from Hallam's (1984) figure and digitally forced to match the same horizontal (sea level) scale as used on the right-hand side. Vertically, the curves for each Epoch of Hallam's (1984) graph were independently stretched to match the geologic time intervals on the right-hand scale, since his Epoch boundaries (here represented by dashed horizontal lines) were not originally attached to a rigorous time scale.
SED

4, 363-428, 2012

\section{In plain sight: the Chesapeake Bay crater ejecta blanket}

D. L. Griscom

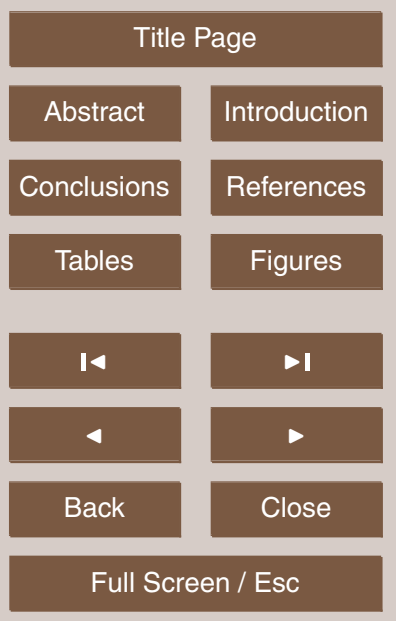

Printer-friendly Version

Interactive Discussion 


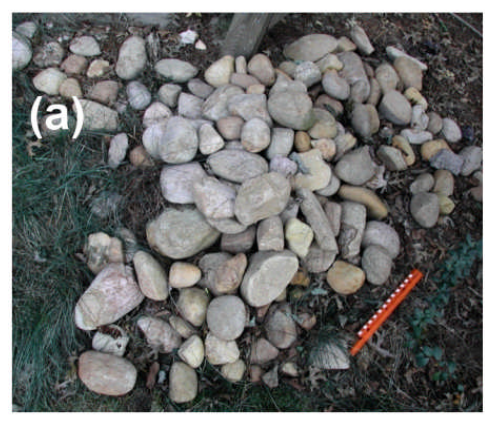

(c)

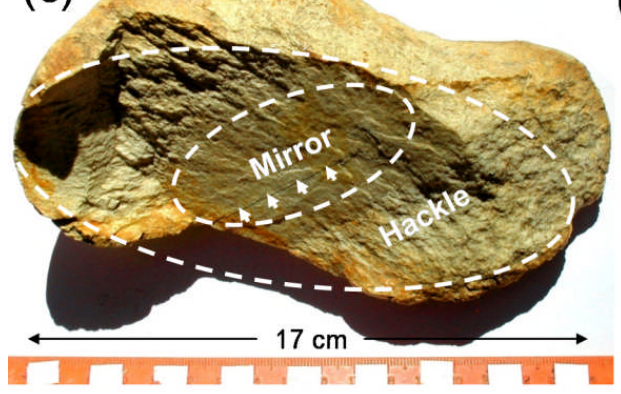

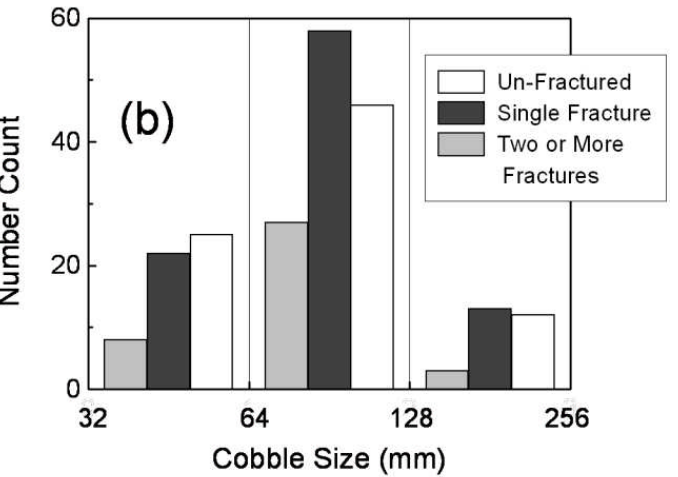

(d)

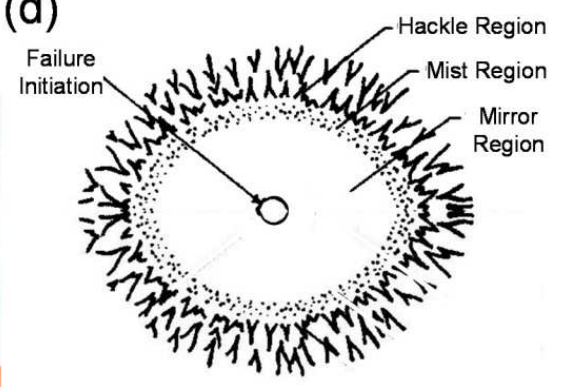

SED

4, 363-428, 2012

\section{In plain sight: the Chesapeake Bay crater ejecta blanket}

D. L. Griscom

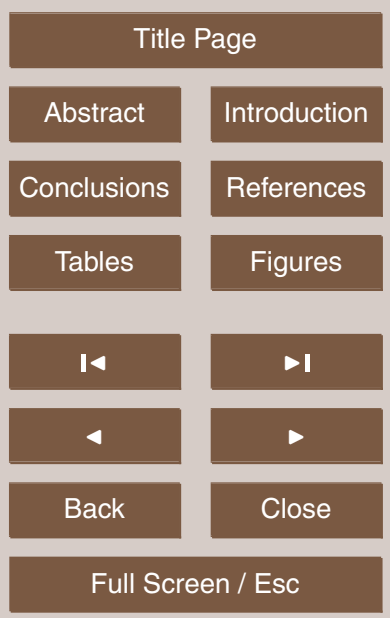

Printer-friendly Version

Interactive Discussion 


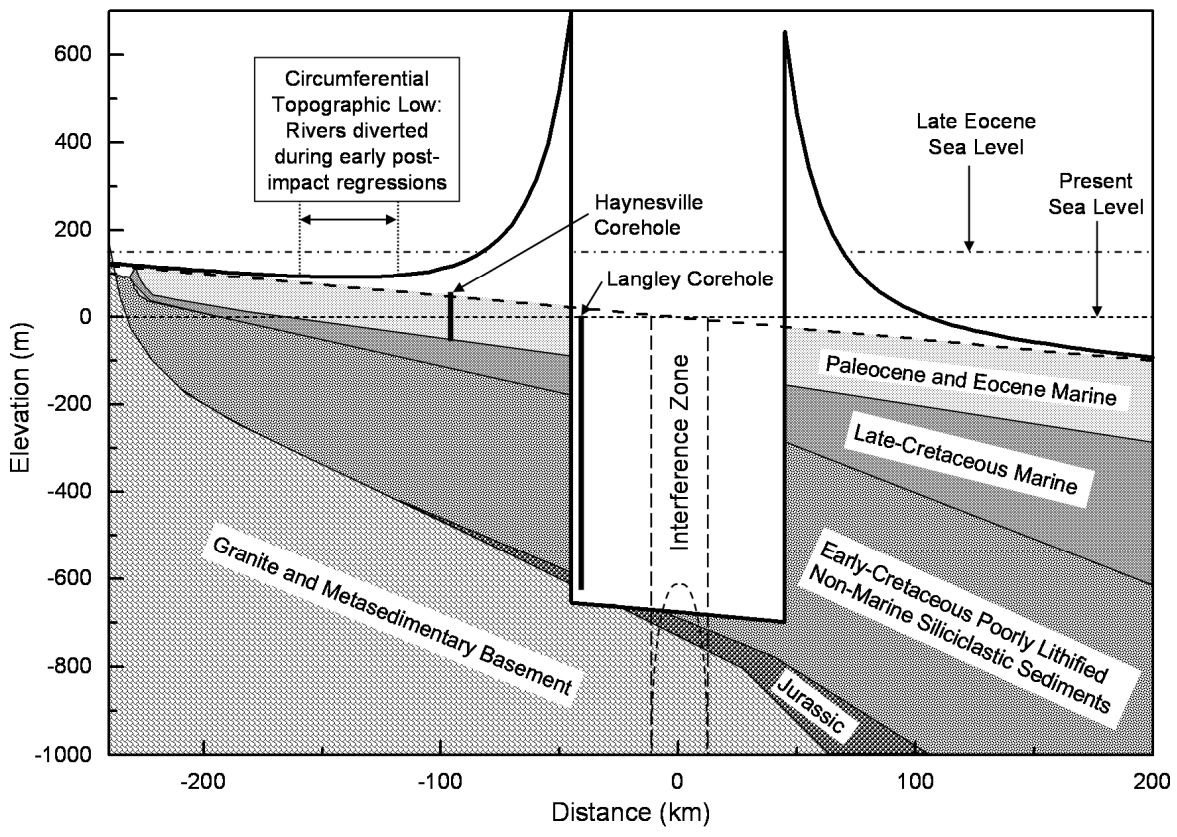

Fig. 8. Lower-limit idealized profile of the Chesapeake Bay crater ejecta blanket minutes after the impact, calculated by means of Eq. (1), assuming a north-northwestward section passing through Southern Maryland, where the coastal-plain sediments are known to slope $\sim 0.5 \mathrm{~m} \mathrm{~km}^{-1}$ downward toward the point of impact. Labeled lithology of the target rocks follows Koeberl et al. (1996) and Poag (1997), and overall sediment depths are scaled to match the depth at which the USGS-NASA Corehole intercepted basement granite (Horton et al., 2005). Also indicated is the effective interference zone from which all materials (outside the footprint of the assumed $6 \mathrm{~km}$-diameter cometary impactor) would have been ejected at high speeds with minimal shocking (Melosh, 1989). The indicated coreholes are shown at the correct distances from the crater center but lie on different radial transects then the one selected.
SED

4, 363-428, 2012

\section{In plain sight: the Chesapeake Bay crater ejecta blanket}

D. L. Griscom

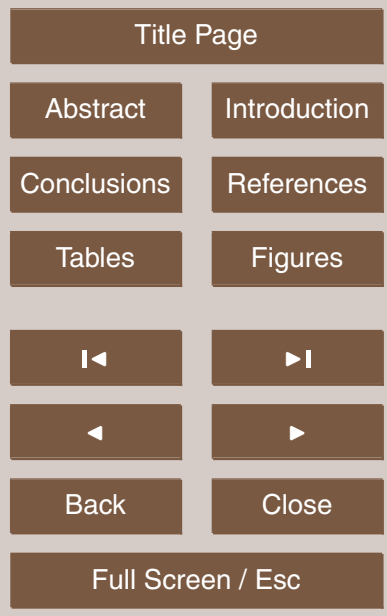

Printer-friendly Version

Interactive Discussion 


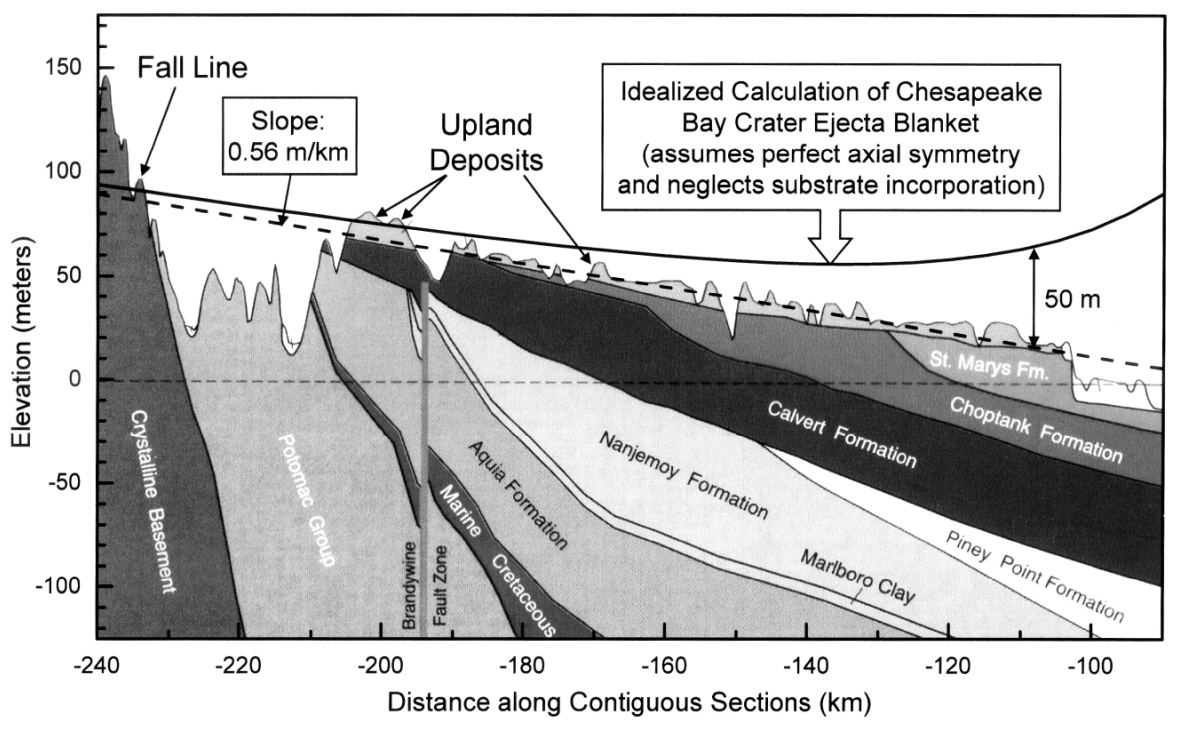

Fig. 9. Generalized stratigraphic section of Southern Maryland reproduced from the work of Krantz and Powars (2000) (labeled gray-scale formations, reproduced courtesy of the U.S. Geological Survey) with comparison to the author's lower-limit calculation of the original Chesapeake Bay crater ejecta blanket (overlain curve, dashed line, and boxed comments). The slightly zigzagging transect lines for this section are reproduced at the top of Fig. 10.

\section{In plain sight: the \\ Chesapeake Bay crater ejecta blanket}

D. L. Griscom

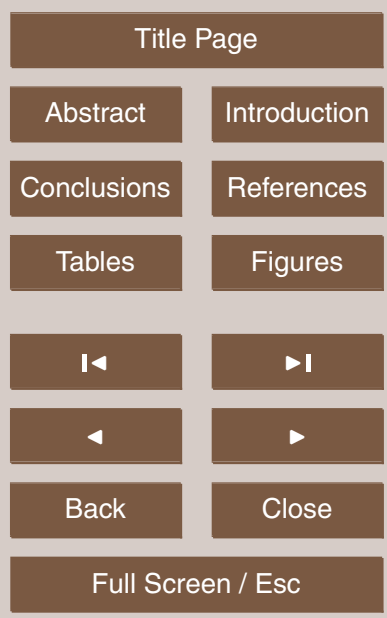

Printer-friendly Version

Interactive Discussion 


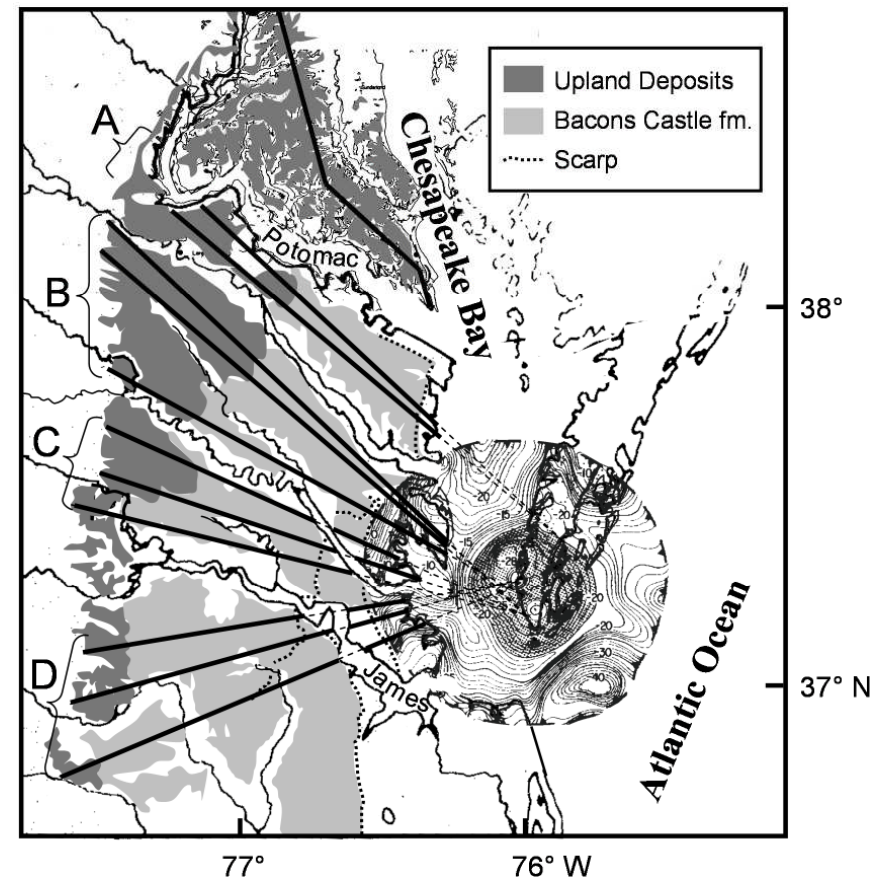

Fig. 10. Map of the upland deposits and Bacons Castle Formation showing transects pertaining to elevation profiles shown in Fig. 9 (Southern Maryland: at top) and in Figs. 11 and 12 (Eastern Virginia: groups A, B, C, and D). Only the transects of group D are truly radial to the center of the crater. The others radiate from points selected to intercept long, mostly continuous stretches of the upland deposits. (The in-crater gravity map is adapted from C. Koeberl, C. W. Poag, W. U. Reimold, and D. Brandt, Science 271, 1263 (1996) and reprinted with permission from AAAS.)

\section{SED}

4, 363-428, 2012

\section{In plain sight: the Chesapeake Bay crater ejecta blanket}

D. L. Griscom

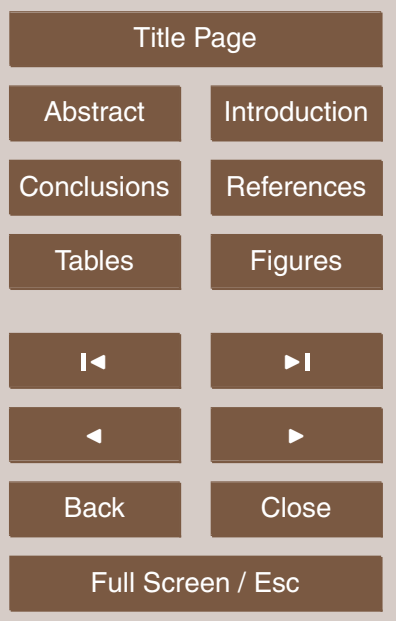

Printer-friendly Version

Interactive Discussion 


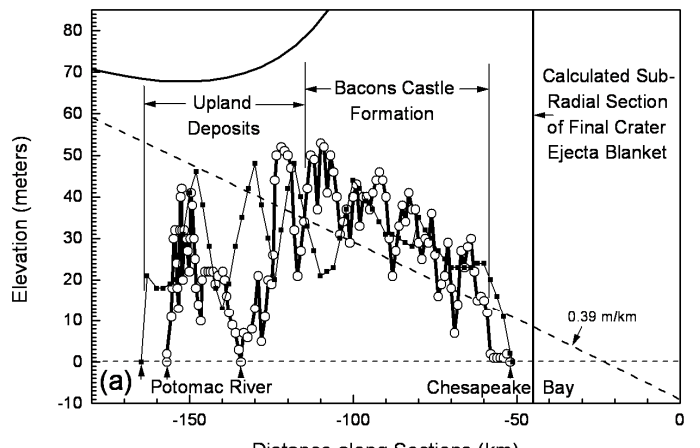

SED

4, 363-428, 2012

\section{In plain sight: the \\ Chesapeake Bay crater ejecta blanket}

D. L. Griscom

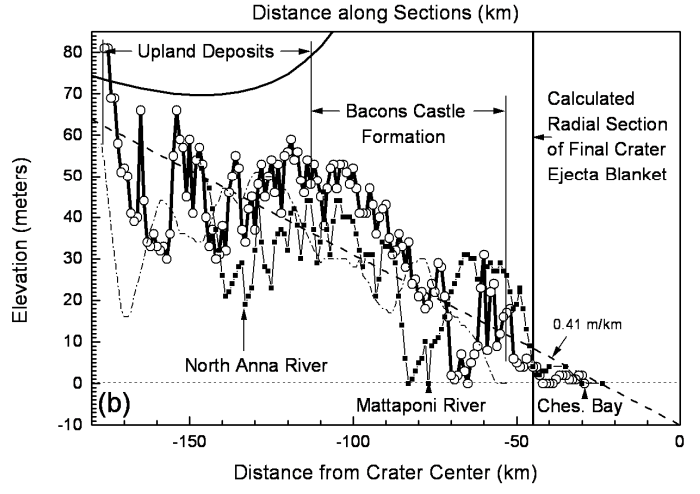

Title Page

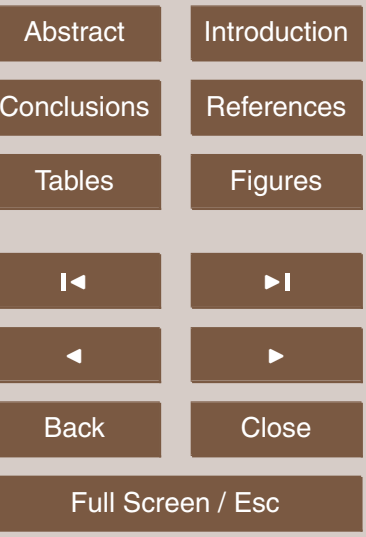

Fig. 11. Elevation profiles of the upland deposits and Bacons Castle Formation in Virginia along transects in groups A and B illustrated in Fig. 10: (a) Group A, Potomac-Rappahannock peninsula and (b) Group B, Rappahannock-York peninsula. The idealized lower-limit CBIS ejecta blanket calculation described in Sect. 5.1 has been overlain on each of these two data sets. Multiple profiles within each graph are arranged so that the southern most transect is represented by small black squares, the central one by large hollow circles, and the northernmost one (absent in (a)) by a dash-dot line. See caption to Fig. 12 for more details. N. B. The low point at $-170 \mathrm{~km}$ in (b) is a subcircular depression (secondary crater?), not a V-shaped valley. 


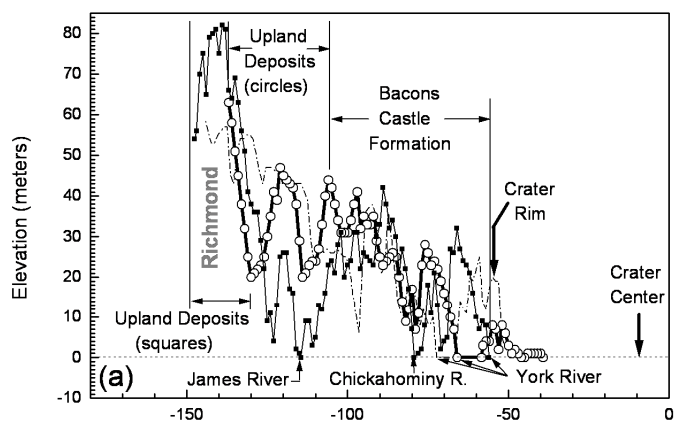

\section{In plain sight: the Chesapeake Bay crater ejecta blanket}

D. L. Griscom

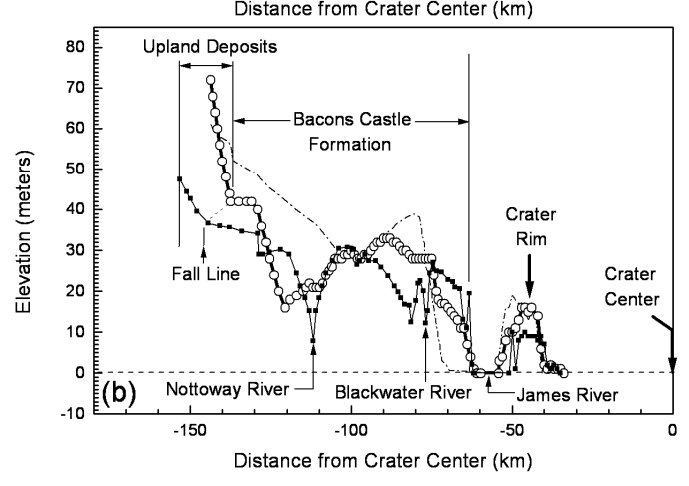

Title Page

Abstract

Conclusions

Tables

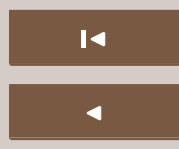

Back
Introduction

References

Figures

- I

$>$

Close along transects in groups C and D illustrated in Fig. 10: (a) Group C, York-James peninsula and (b) Group D, area south of the James River. Multiple profiles within each graph are arranged so that the southern most transect is represented by small black squares, the central one by large hollow circles, and the northernmost one by a dash-dot line. The spatial resolution of these elevation data (and also those of Fig. 11) varies as a function of the eye altitude "flown" on Google Earth. Thus, data showing high spatial frequency of hills and valleys were "flown" at an eye altitude typically $\sim 10-20 \mathrm{~km}$, while those displaying only low-frequency elevation changes were "flown" at eye altitudes of $\sim 50 \mathrm{~km}$ or more. In (b), high-altitude data were supplemented by limited low-altitude data to sharpen river valleys and scarps.

Full Screen / Esc

Printer-friendly Version

Interactive Discussion 


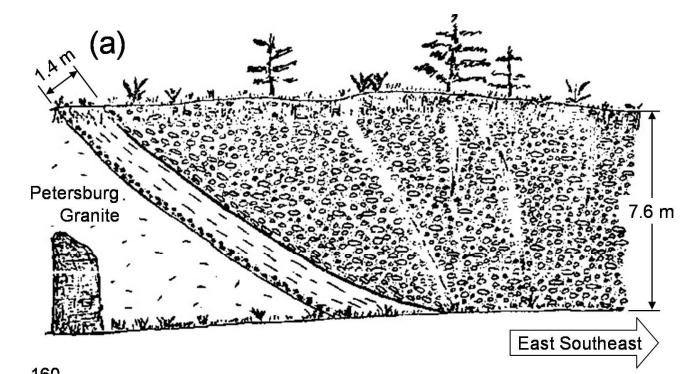

\section{In plain sight: the Chesapeake Bay crater ejecta blanket}

D. L. Griscom

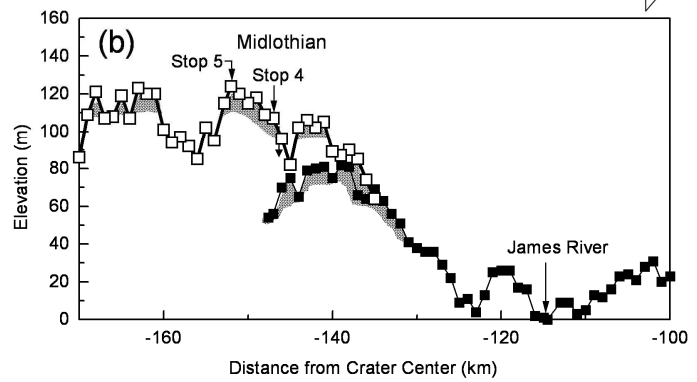

Title Page

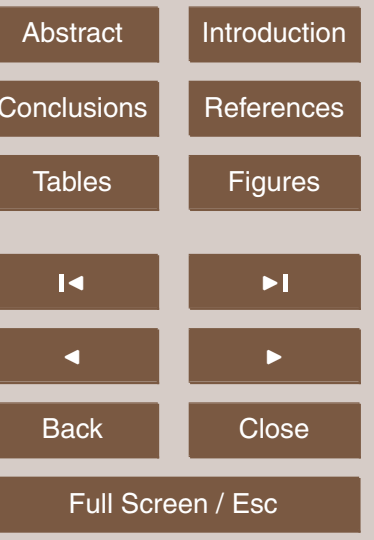

Fig. 13. (a) Sketch of the outcrop of Midlothian upland gravels at Stop No. 4 of Goodwin and Johnson's (1970) field trip. (b) Elevation profile of the Midlothian upland deposits along U.S. Route 60 west of Richmond, Virginia (hollow squares), with comparison to a radial profile roughly $8 \mathrm{~km}$ southward (black squares; also shown in Fig. 12a). All distances are relative to the center of the CBIS. Shaded areas represent the author's general understanding of the approximate lateral and vertical extents of the upland deposits along these profiles, based on Frye's (1986) map and Goodwin and Johnson's (1970) written account.

Printer-friendly Version

Interactive Discussion 


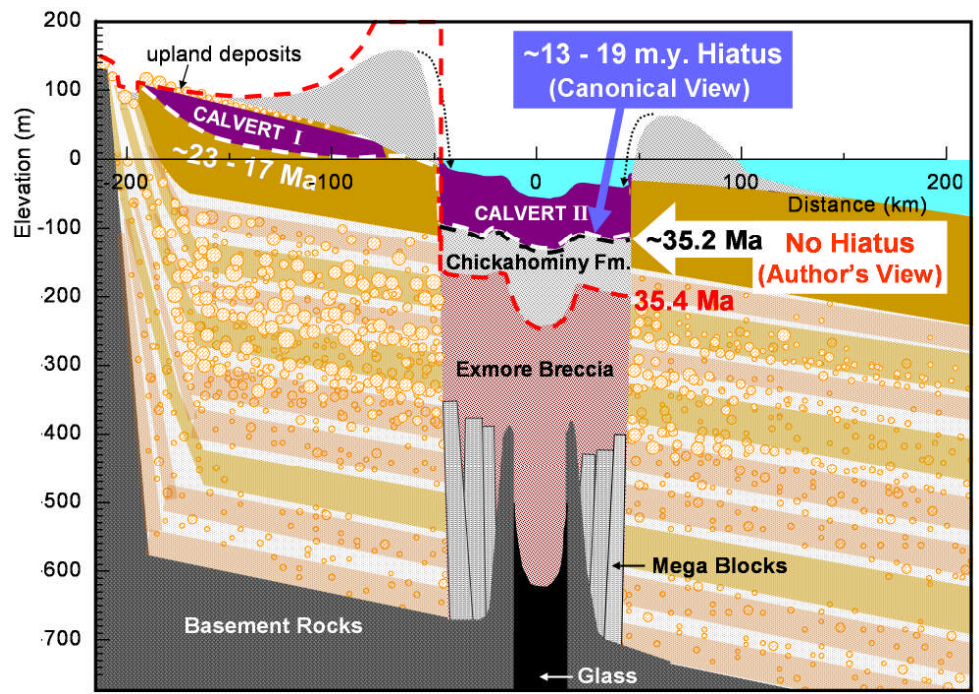

\section{In plain sight: the Chesapeake Bay crater ejecta blanket}

D. L. Griscom

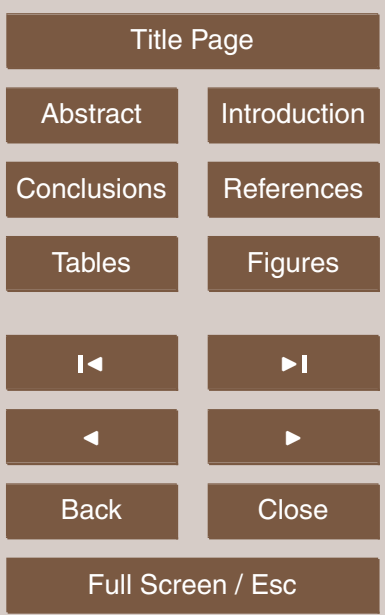

Fig. 14. Quasi-to-scale section of the Chesapeake Bay Impact Structure as it might have looked during a sea-level regression 1-5 m.y. after the impact. The dashed red and white lines represent two imaginable isochrons. The white one portrays a symbolic variant of the current canonical view (cf. text), whereas the red one is the author's view, which includes his inference that mass wasting of the original ejecta blanket was the sole - and unceasing - source of the lithic components of both in-crater formations, i.e. both the Chickahominy Fm. and "Calvert II." The black dashed line marked as $\sim 35.2 \mathrm{Ma}$ represents the author's best guess as to the time of the extinction of the planktonic foraminiferal assemblage defining the Chickahominy Fm., based on reasoning evoked in Sect. 7.3.1. The biostratigraphic columns of both "Calvert I" and "Calvert II" (present author's shorthand terminology: cf. text) were determined by Poag and Aubry (1995), Poag and Cammeau (1995), and Poag (1997), who tacitly assume that both Calverts were emplaced in a relatively short time interval centered somewhere between $\sim 23$ and $17 \mathrm{Ma}$, resulting in a $\sim 13$ to $19 \mathrm{~m}$.y. hiatus at the in-crater Chickahominy/Calvert Il interface.

Printer-friendly Version

Interactive Discussion 


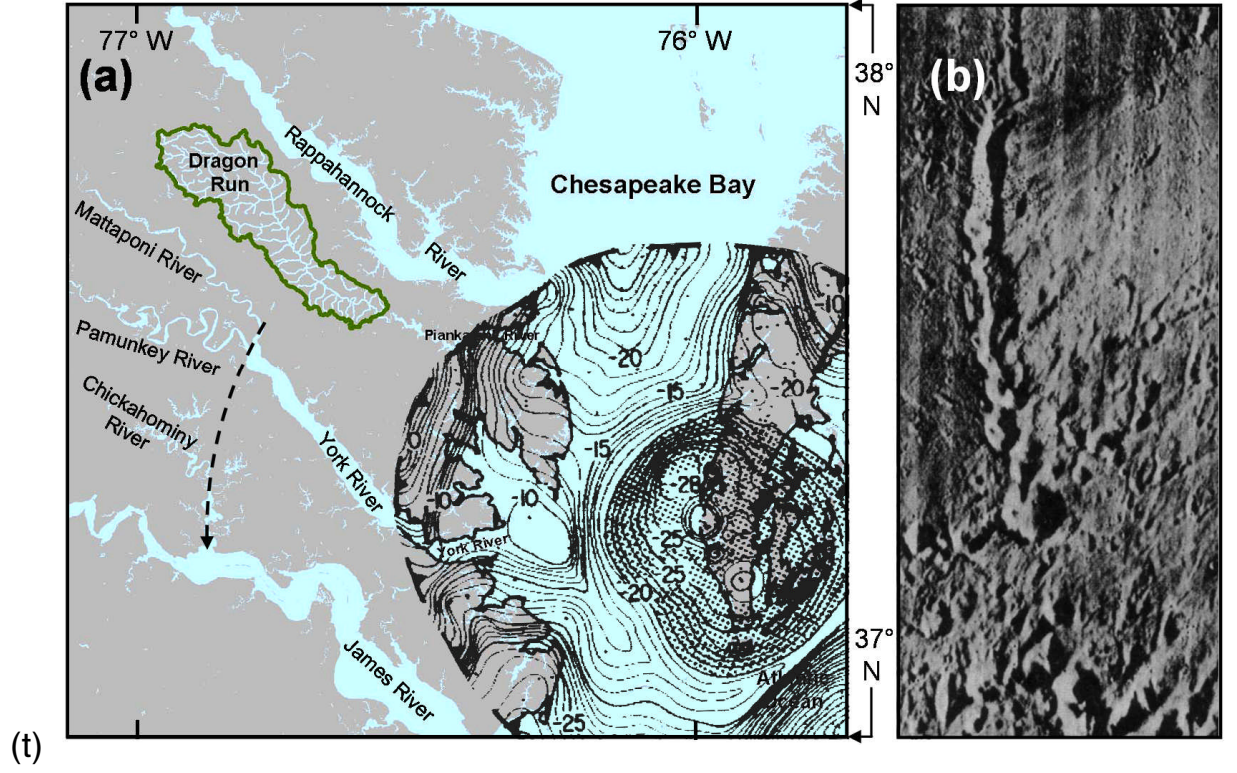

Fig. 15. (a) Location of the Dragon Run watershed (reproduced from Dragon Run Steering Committee, The State of Dragon Run Water Shed: State of Natural Resources, Middle Peninsula Planning District Commission, 2003), relative to the Chesapeake Bay impact structure indicated by a superposed gravity map within the crater rim (adapted from C. Koeberl, C. W. Poag, W. U. Reimold, and D. Brandt, Science 271, 1263 (1996) and reprinted with permission from AAAS). (b) Linear string of secondary impacts associated with the Lunar crater Copernicus (NASA Lunar Orbiter photograph LO IV H121). The Dragon Run watershed in (a) is a similar raised-rim depression. Its boundary is a fluvial-transport divide; all streams inside it flow inward. Dashed arrow indicates an author-proposed circumferential paleochannel of the ancestral York River before it breached the crater rim (cf. text).

\section{SED}

4, 363-428, 2012

\section{In plain sight: the Chesapeake Bay crater ejecta blanket}

D. L. Griscom

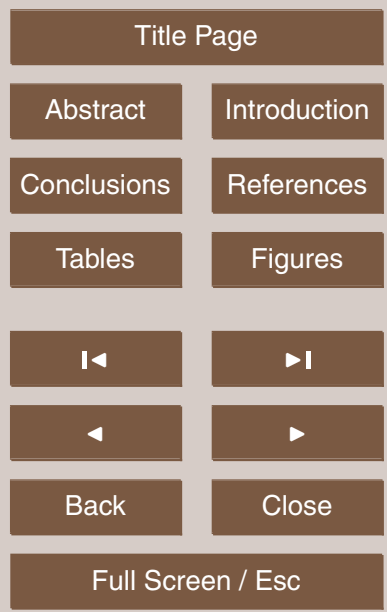

Printer-friendly Version

Interactive Discussion

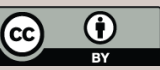



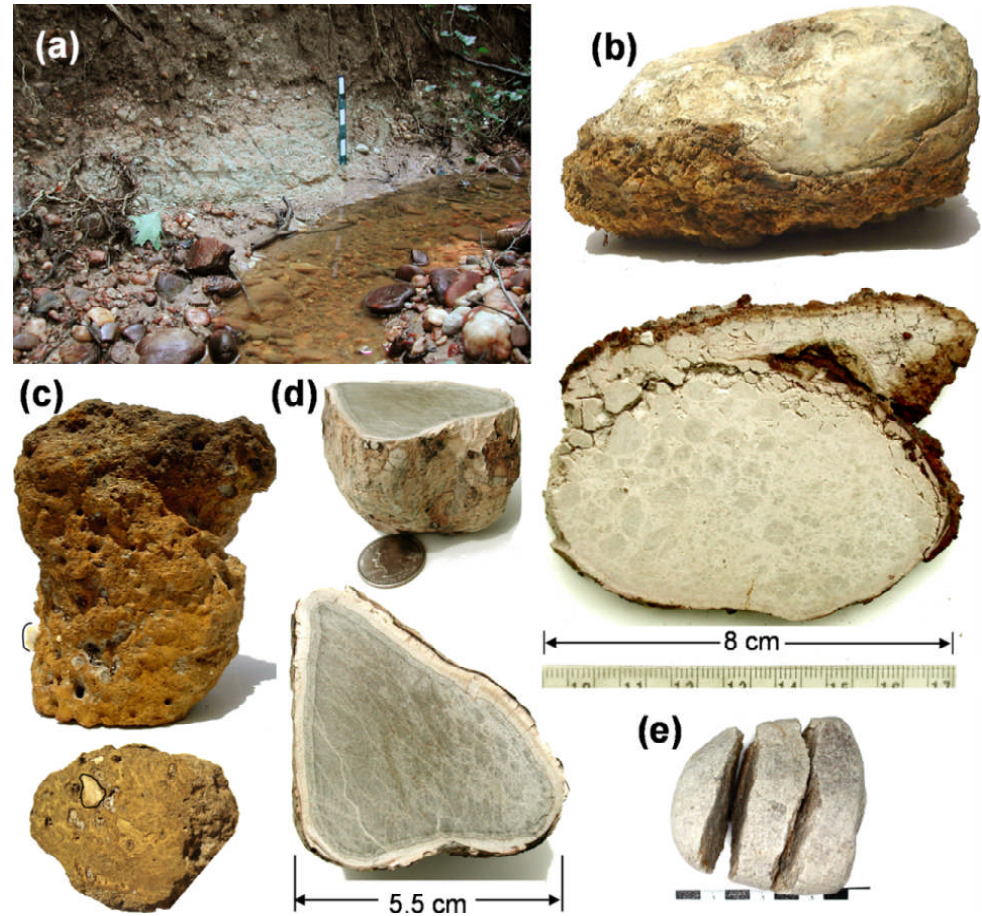

(d)
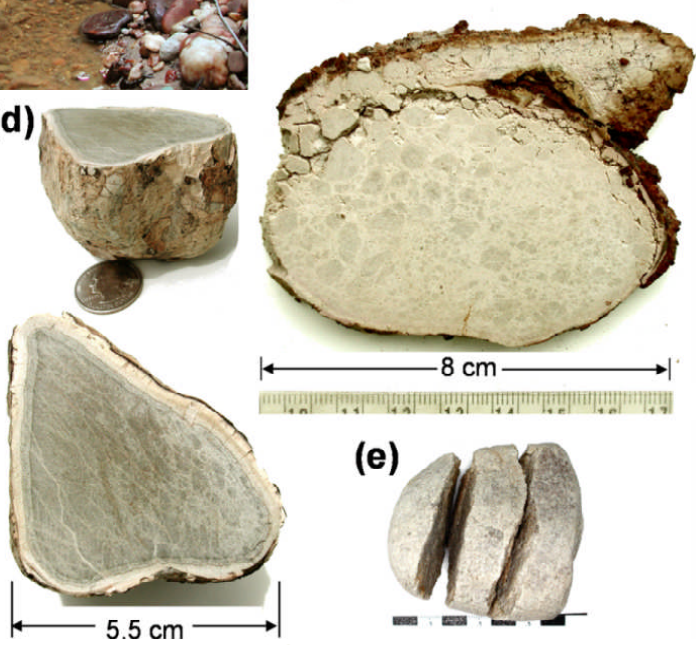

(e)

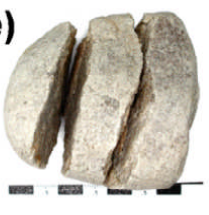

Fig. 16. (a) The Hollin Hills Diamicton: a massive unsorted whitish-gray (green tinge is false) siliciclastic stratum $\sim 30 \mathrm{~cm}$ high above the stream bed and an unknown depth below it (scale bars: $5 \mathrm{~cm}$ ). (b) Autobrecciated chalk ball manually exhumed from the stream bed just outside the field of view of (a) to the right. (c) Massive "cinder" composed of iron oxide, quartz silt, likely some glass, and 5-10 $\mathrm{mm}$ quartz clasts (outlined in black) recovered well outside the field of view of (a) to the left. (d) Clay clast with a multi-layer external coating recovered from the stream bed. (e) Multiply-fractured quartzite cobble found nested elsewhere in this stratum.

SED

4, 363-428, 2012

\section{In plain sight: the \\ Chesapeake Bay crater ejecta blanket}

D. L. Griscom

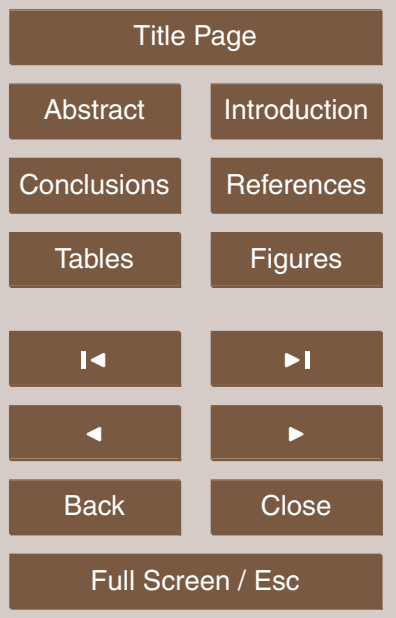

Printer-friendly Version

Interactive Discussion 

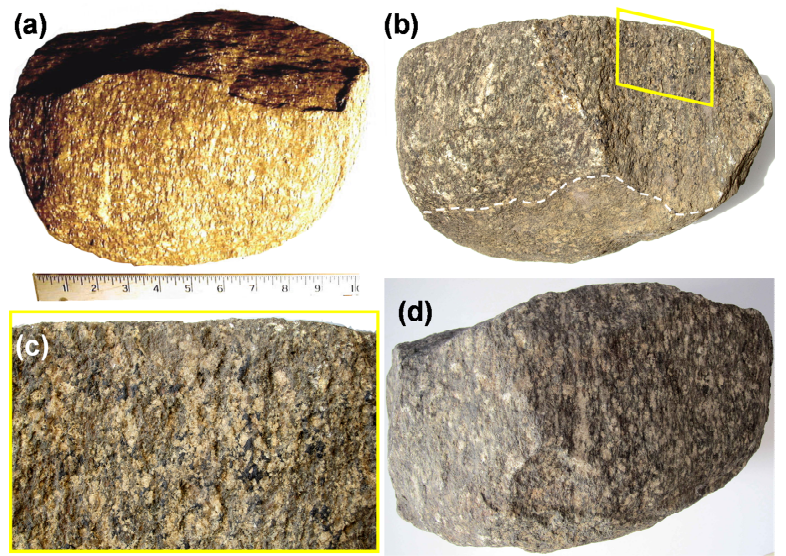

(e)
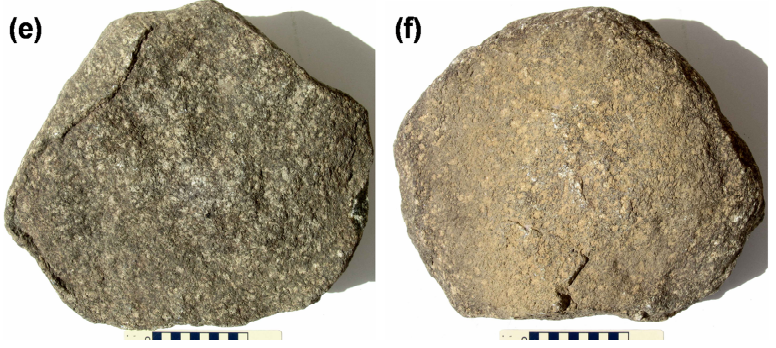

Fig. 17. An allogenic $27 \mathrm{~kg}$ granite boulder discovered by the author in Fairfax County, Virginia: (a) False color, lit by a pair of floodlights (scale: inches). (b) Same object in full sunlight, anterior dome is below the dashed white line. (c) Close-up of yellow box in (b) showing jet-black patches tentatively identified as "puddles" of biotite quenched from the molten state (width, $10 \mathrm{~cm}$ ). (d) Diffuse skylight indoors seems to increase visibility of vertical streaks. (e) and (f): Posterior and anterior surfaces, respectively recorded by flipping the object $180^{\circ}$ about the inpage vertical axis under identical lighting conditions (direct sunlight from upper left). Scale bars in (e) and (f) in centimeters.
SED

4, 363-428, 2012

\section{In plain sight: the \\ Chesapeake Bay crater ejecta blanket}

D. L. Griscom

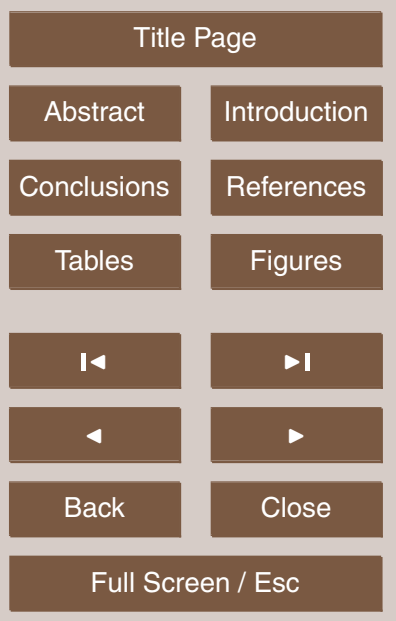

Printer-friendly Version

Interactive Discussion 